\title{
MANAGEMENT STRATEGIES FOR PITCH CANKER INFECTED AÑO NUEVO STANDS OF MONTEREY PINE
}

\author{
A Thesis \\ Presented to the Faculty of \\ California Polytechnic State University \\ San Luis Obispo \\ In Partial Fulfillment of the \\ Requirements for the Degree of \\ Master of Science in Forestry Sciences
}

By

Valerie A. Loe

June 2010 
(C) 2010

Valerie A. Loe ALL RIGHTS RESERVED 


\section{APPROVAL PAGE}

TITLE: Management Strategies for Pitch Canker Infected Año Nuevo Stands of Monterey Pine

AUTHOR: Valerie A. Loe

DATE SUBMITTED: June, 2010

COMMITTE CHAIR: Dr. Walter Mark, PhD., RPF

Natural Resource Management Department

COMMITTEE MEMBER: Dr. Douglas Piirto, PhD., RPF

Natural Resource Management Department

COMMITTEE MEMBER: Dr. Ulric Lund, PhD.

Statistics Department 


\section{ABSTRACT \\ MANAGEMENT STRATEGIES FOR PITCH CANKER INFECTED AÑO NUEVO STANDS OF MONTEREY PINE}

Valerie A. Loe

The future resilience of Pinus radiata D. Don (Monterey pine) is dependent upon the development of a silviculture program inclusive of either preventative or management techniques for the potentially fatal pitch canker disease (Fusarium circinatum Nirenberg and O'Donnell [=F .subglutinans (Wollenw. \& Reinking) Nelson et al. f. sp. Pini). As an ecologically and commercially valued species, a myriad of factors threaten the genetic resources of the geographically limited natural range. This study evaluated the effectiveness of uneven-aged forest management for regeneration success in the native, pitch canker infected Año Nuevo stand at Swanton Pacific Ranch in Davenport, California. Seedling survival and growth averages were used to evaluate the impact of the variables of gap size ( 0.20 -hectare, 0.10 -hectare, and 0.05-hectare), site-preparation treatment (pile and burn, lop and scatter), and parent tree (13 local seed sources). Pitch canker symptoms were quantified to conclude if there is indeed a range of expressed resistance according to parent tree.

Statistical models (i.e. 'mixed effect') yielded moderately significant differences in odds of survival between site treatments, with pile and burn plots producing higher survival rates $(\mathrm{p}=0.066)$. No significant difference in survival was detected between gap-sizes $(\mathrm{p}=0.936$ and $0.803,0.05$ - and 0.10 hectare gaps respectively to 0.20 -hectare reference). Significant variation was expressed (estimate $=0.1219$, $\mathrm{SE}=0.057$ ) between the 13 parent trees, implicating usefulness in predicting seedling survival. 'Mixed effect' models only detected a significant effect from gap-size on growth measures: 0.20-hectare gaps yielded height and diameter measures significantly larger than 0.05 -hectare gaps ( $\mathrm{p}=0.027$ and 0.0081 respectively). Contingency tables detected significant association between gap-size and number of pitch canker branch symptoms. The range of infection rates produced by the 13 parent trees did not prove significant by analysis. Pile and burn site preparation treatment increases the probability of survival for artificially regenerated seedlings and 0.20 -hectare gaps yield significantly higher growth averages over 0.05-hectare gaps. 


\section{ACKNOWLEDGEMENTS}

My participation in this project has been both an honor and a testament to the power of a team. Many groups and individuals have contributed to this study, all of whom I would like to express my appreciation. I would like to specifically recognize our funding sources for the pivotal role they played. The California Department of Forestry and Fire Protection (CDF) granted financial support with matching funds provided by the California State University Agricultural Research Initiative (ARI).

Thank you to my committee, Dr. Walter Mark, Dr. Douglas Piirto, and Dr. Ulric Lund for their willingness to take a chance on an artist. I am grateful for the guidance and expertise they supplied, which helped me conquer this challenge and bring their vision to fruition.

I have the utmost admiration and appreciation for the efforts of Elicia Wise, Jason Pinkerton and David Yun. The portions of this project they accomplished were undoubtedly invaluable to realization of the study.

Through the years since the project commenced, the energy and time from numerous Cal Poly students has enabled successful implementation and continuation. I thank them all for their sweat, blood and sore muscles. I specifically want to express my heart-felt gratitude to Catherine Wiegers, Mike Papa, Brian Dotters, Tom Lloyd, Sarah Mark, Steve Auten and the rest of the Swanton Pacific Ranch staff for their collaboration and encouragement.

To my amazing parents and grandma, I am endlessly indebted for their unwavering confidence and support in my decision to pursue this degree. I would also like to thank my family and friends for keeping a smile on my face. To Andy, a special thanks for her motivation, moral support, listening ears and open heart. 


\section{TABLE OF CONTENTS}

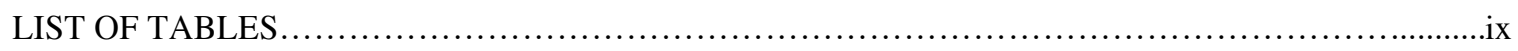

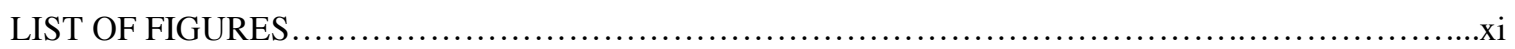

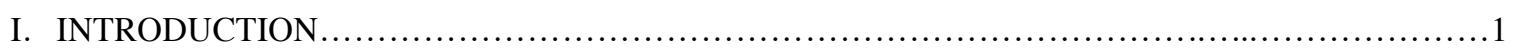

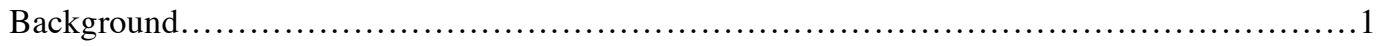

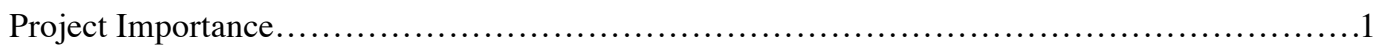

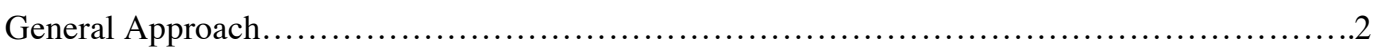

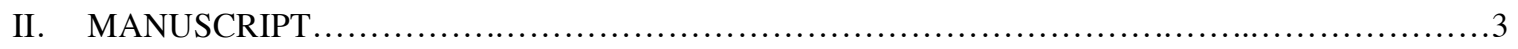

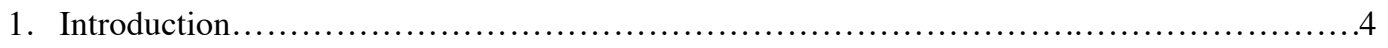

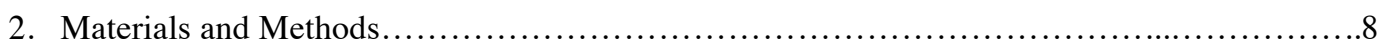

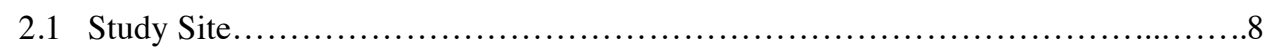

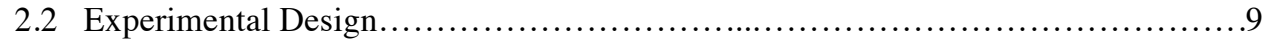

2.3 Field Procedures.........................................................

Plot Location.......................................................... 10

Gap Creation and Site Preparation........................................10

Reforestation.......................................................

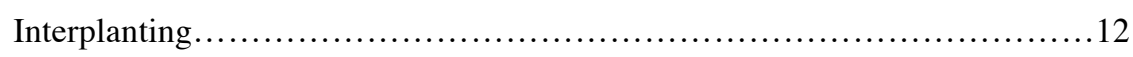

2.4 Data Collection and Analyses................................................ 13

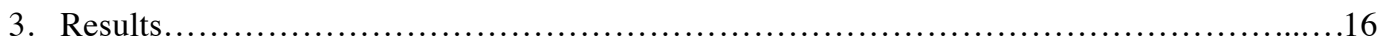

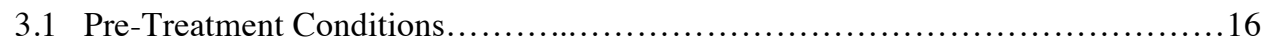

3.2 Understory Vegetation.............................................................

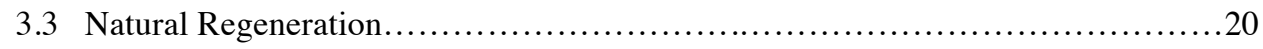

3.4 Survival of Artificially Regenerated Seedlings...............................20

3.5 Growth of Artificially Regenerated Seedlings................................25

3.6 Disease Symptom Occurrence................................................

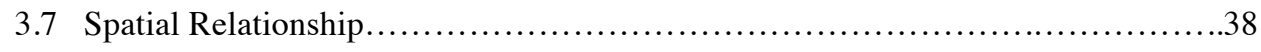

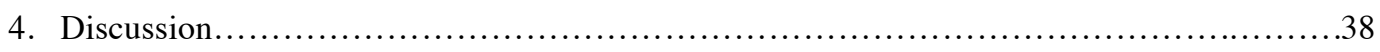




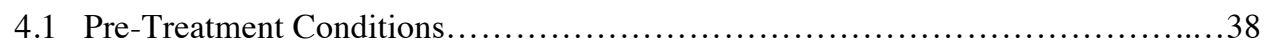

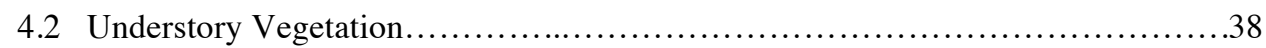

4.3 Natural Regeneration..............................................40

4.4 Survival of Artificially Regenerated Seedlings $\ldots \ldots \ldots \ldots \ldots \ldots \ldots \ldots \ldots \ldots \ldots \ldots . \ldots \ldots$

4.5 Growth of Artificially Regenerated Seedlings..............................42

4.6 Disease Symptom Occurrence.......................................43

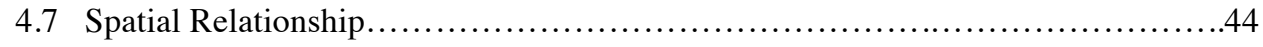

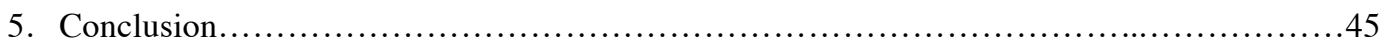

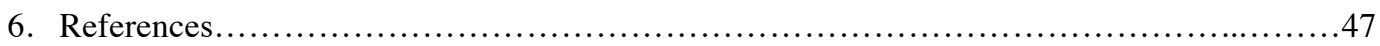

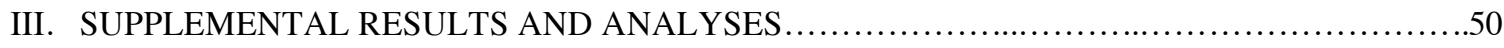

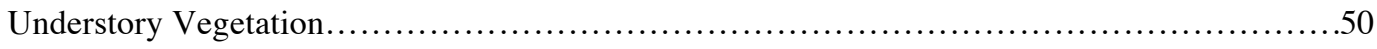

Growth of Artificially Regenerated Seedlings.............................................

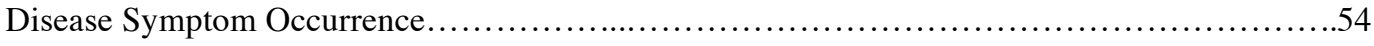

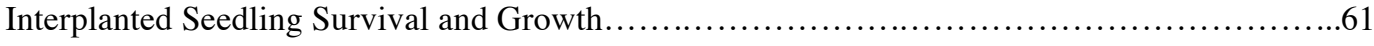

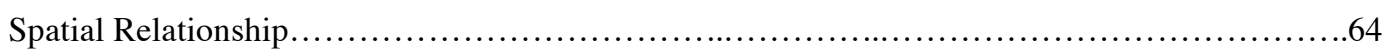

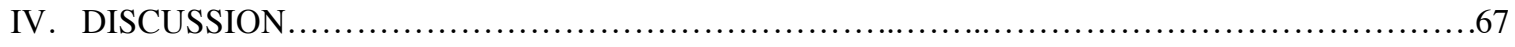

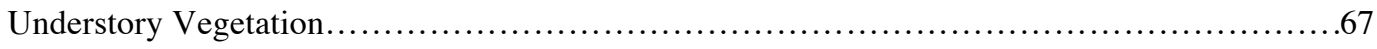

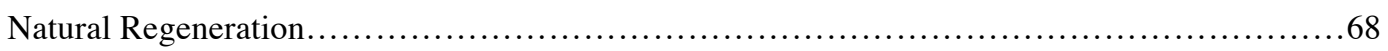

Survival of Artificially Regenerated Seedlings.......................................69

Growth of Artificially Regenerated Seedlings......................................71

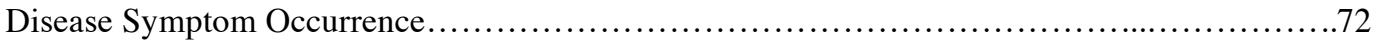

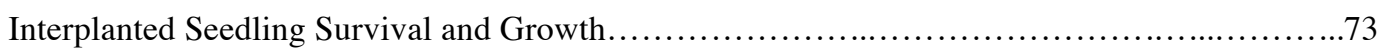

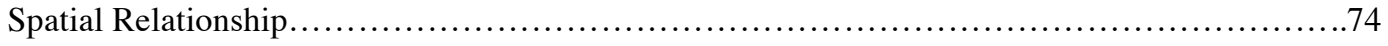

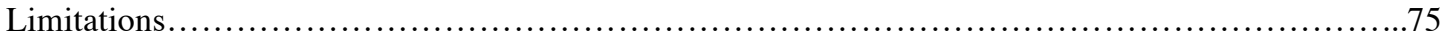

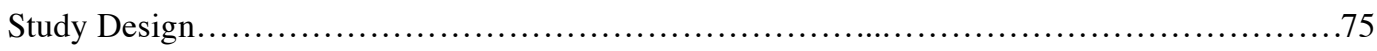

Environmental Conditions.................................................... 76

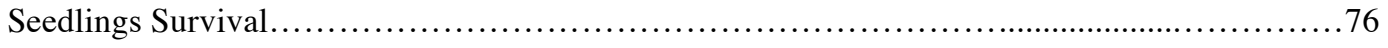




\section{MANAGEMENT IMPLICATIONS AND RECOMMENDATIONS}

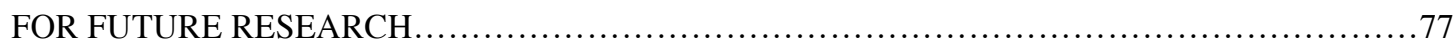

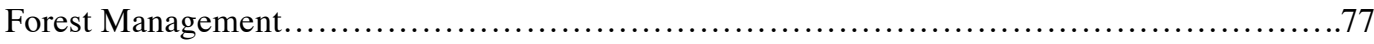

Future Research Needs.......................................................78

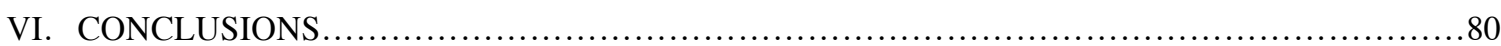

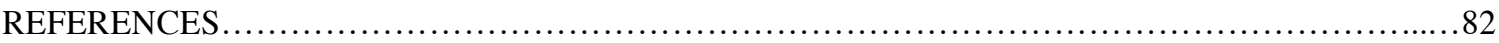

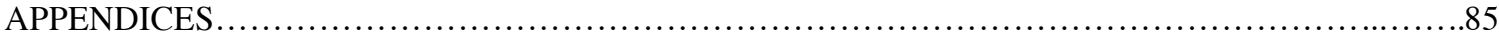

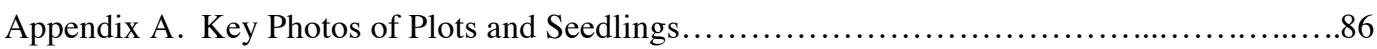

Appendix B. Natural Regeneration Details: 12-, 24-, and 68 months Post-Treatment............92

Appendix C. Survival and Mortality Details: 68 months Post-Treatment.....................95

Appendix D. Growth Averages: 12-, 24-, and 68 months Post-Treatment.......................98

Appendix E. Spatial Relationship Schematic..........................................101

Appendix F. Photographic Record 68 Months Post-Treatment........................... 103

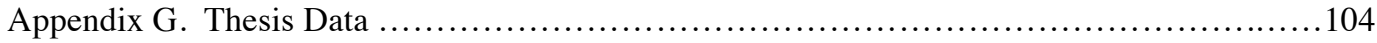




\section{LIST OF TABLES}

Table 1. Radius and area of study plots. 10

Table 2. Seedling resistance rating by parent as determined by screening of original parent trees in June 1999 and June 2000.

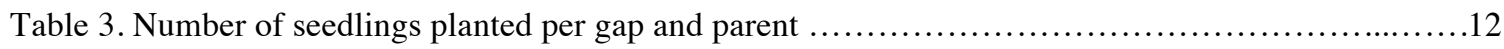

Table 4 . Number of interplanted seedlings by parent............................................

Table 5. Number of sample seedlings planted by parent and gap for all 18 treated gaps...................14

Table 6. Predominant under- and over-story species observed within the study site $\ldots \ldots \ldots \ldots \ldots \ldots \ldots \ldots \ldots$

Table 7. Summary of naturally regenerated seedlings by treatment and gap-size at

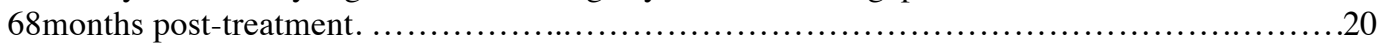

Table 8 . Survival rate, by parent, gap size and treatment independently ( $68 \mathrm{~m}$ post-treatment)............23

Table 9. Survival \# and rate by gap-size and treatment in unison at post-treatment 12-, 24-, and $68 \mathrm{~m}$ post-treatment.

Table 10. Coefficients and odds ratio for fixed effects in model predicting survival in $68 \mathrm{~m}$ post-treatment. 24

Table 11. Covariance Parameter Estimates for model prediction survival at 68 months

Table 12. Descriptive statistics for height $(\mathrm{cm})$ for sample trees at $68 \mathrm{~m}$ post-treatment. .28

Table 13. Descriptive statistics for diameter $(\mathrm{mm})$ for sample trees at $68 \mathrm{~m}$ post-treatment. .28

Table 14. Coefficients for fixed effects in model predicting height at 68 months. .30

Table 15. Tukey-Kramer Adjustment for height of sample trees at 68 months by gap-size...................30

Table 16. Covariance Parameter estimates in model predicting height at 68 months....

Table 17. Coefficients for fixed effects in model predicting diameter at 68 months. .32

Table 18. Tukey-Kramer Adjustment for diameter of sample trees at 68 months by gap-size......

Table 19. Covariance Parameter estimates in model predicting diameter at 68 months.

Table 20. Descriptive statistics for pitch canker branch-tips symptoms by parent, gap-size, treatment, tree height, and resistance rank at $68 \mathrm{~m}$ post-treatment inclusive of p-values for associations determined by contingency tables....

Table 21. Descriptive statistics for pitch canker stem symptoms by parent, gap-size, treatment, tree height, and resistance rank at $68 \mathrm{~m}$ post-treatment

Table 22. Descriptive statistics for western gall rust symptoms by parent, gap-size, treatment, tree height, and resistance rank at $68 \mathrm{~m}$ post-treatment inclusive of $\mathrm{p}$-values for associations determined by contingency tables.....

Table 23. Survival by parent of interplanted seedlings at $68 \mathrm{~m}$ post-treatment. 62 
Table 24. Survival by parent of original seedlings at $68 \mathrm{~m}$ post-treatment...........................62

Table 25. Survival rates for interplanted seedlings by parent, gap size and treatment

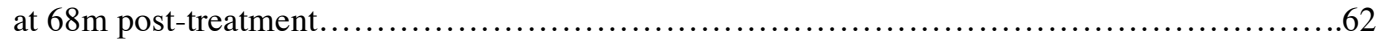

Table 26. Descriptive statistics for height $(\mathrm{cm})$ of interplanted seedlings

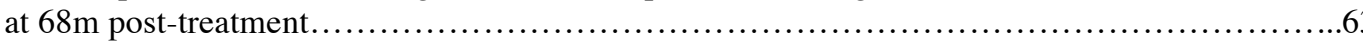

Table 27. Descriptive statistics for diameter $(\mathrm{mm})$ of interplanted seedlings at $68 \mathrm{~m}$ post-treatment.

Table 28. Survival results for spatial analysis for quadrants aligned with the sun's azimuth for 6 days of the year, 2003; 24m post-treatment data

Table 29. Height $(\mathrm{cm})$ results from spatial analysis for quadrants aligned with the sun's azimuth for 6 days of the year, 2003; 24m post-treatment data. 


\section{LIST OF FIGURES}

Figure 1. Summary of understory vegetation cover $(\%)$ for study site at pre-, post-treatment $12,24 \& 72 \mathrm{~m}$ post-treatment.

Figure 2. Illustration of survival rates (\%) of all original seedlings at $68 \mathrm{~m}$ post-treatment by treatment, gap size, and parent.

Figure 3. Average height $(\mathrm{cm})$ over time by treatment, gap-size and parent for a sample of 271 seedlings.

Figure 4. Average diameter $(\mathrm{mm})$ over time by treatment, gap-size and parent for a sample of 271 seedlings.

Figure 5. I Illustration of summaries for understory vegetation cover (\%) for 0.20 ha plots at pre-, post-treatment 12,24 and $68 \mathrm{~m}$ post-treatment.

Figure 6. Illustration of summaries for understory vegetation cover (\%) for 0.10 ha plots at pre-, post-treatment 12,24 and $68 \mathrm{~m}$ post-treatment.

Figure 7. Illustration of summaries for understory vegetation cover (\%) for 0.05 ha plots at pre-, post-treatment 12,24 and $68 \mathrm{~m}$. post-treatment.

Figure 8. Illustration of results from contingency tables for associations between pitch canker branch-tips to independent variables at $68 \mathrm{~m}$ post-treatment....

Figure 9. Illustration of results from contingency tables for associations between gall rust symptoms to independent variables and pitch canker branch-tips at $68 \mathrm{~m}$ post-treatment. 


\title{
INTRODUCTION
}

\section{MANAGEMENT STRATEGIES FOR PITCH CANKER INFECTED AÑO NUEVO STANDS OF MONTEREY PINE}

\author{
Valerie A. Loe
}

\section{Background}

Monterey pine (Pinus radiata D. Don) is one of the most widely exported and planted trees in the world. Yet, little is known about management techniques to sustain forest health and reproduction in the limited native stands that occur in California (Cope, 1993; Smith et al, 1997). The remaining five native stands that represent only a small portion of the historical range are considered to be a critical genetic resource (Rogers, 2002). A variety of ecological (e.g., pitch canker disease) and anthropogenic factors (e.g., urban development, fragmentation) are affecting these native stands (Rogers, 2004).

Three of the native stands are found along California's coast with the northern most being the Año Nuevo stand reaching $37^{\circ} 8^{\prime} \mathrm{N}$, the southern most being the Cambria population at $35^{\circ} 34^{\prime} \mathrm{N}$, and lying between is the Monterey Peninsula population $\left(36^{\circ} 35^{\prime} \mathrm{N}\right.$ ) (Moulds, 1950; Forde, 1964). The other two stands are found on the Cedros and Guadalupe islands off the coast of Baja, Mexico (Libby et al, 1968).

Due to the geographic division the trees of each stand are genetically distinct from each other (i.e. Mexican populations represent a variety (P.r. var. binata)) and comprise variability vital for the future of the species in the face of threatening factors (Deghi et al., 1995; Stuart \& Swayer, 2001).

\section{Project Importance}

Although Monterey pines have proven to be a valuable lumber and landscaping commodity, these trees also play a part in their domestic ecosystem by influencing wildlife habitat and the aesthetics of the environment. Due to the threats posed by urbanization and exotic pathogens, namely pitch canker, the native stands may quickly disappear taking with them a critical pool of genetic material. A lack of sufficient regeneration in and of itself provides enough motivation to develop a management plan for native Monterey pine stands yet the recent impact of pitch canker emphasizes the importance of a program (Storer 
et al., 2001). Research and evaluation could radically improve and restore health in native stands, positively impacting their native environment and international prospects.

The handful of southern hemisphere countries that have adopted Monterey pine for lumber, pulp, and landscaping, would greatly benefit from a management plan for pitch canker. Although some planted populations remain uninfected by the pathogen the increased means of transportation coupled with insufficient knowledge for management present threat of infection. The New Zealand and Australian plantations are prime examples of populations that could potentially remain unaffected by the disease and the consequential losses. Impacted would be the private and public landowners, commercial nurseries and seed orchards, commercial lumber companies and their patrons. Likewise, information regarding heritability of resistance and pathogen behavior will augment preventative practices within management plans for Monterey pines and other conifers impacted by the disease.

\section{General Approach}

As designed by the Cal Poly team of graduate students and professors, this study was set for a five year, post-treatment growing period with several intermittent evaluations. The knowledge gained will provide information to guide development of a suitable management program. Each data collection period afforded the in-field experience and data for three thesis projects: E. Wise (2005), J. Pinkerton (2006) and V. Loe (document author; 2010).

Due to the lengthy nature of the project and the intention of submission to an appropriate scientific journal, the format for this document will deviate from the more conventional design of a master's thesis. Specifically, the manuscript for the article will be included as a chapter, replacing extensive Introduction, Literature Review, and Materials \& Methods sections. For full report of these sections, please refer to the master's thesis of Elicia Wise and Jason Pinkerton. The journal manuscript will highlight key points of the aforementioned sections, Results, Discussion and Conclusion. Following the manuscript chapter will be a supplemental Results section, which will augment with information less pertinent to the manuscript as well as a full account of the project's Discussion, Recommendations and Conclusion. 


\title{
MANUSCRIPT
}

MANAGEMENT STRATEGIES FOR PITCH CANKER INFECTED AÑO NUEVO STANDS OF MONTEREY PINE

\author{
Valerie Loe \\ Elicia Wise \\ Jason Pinkerton \\ Reedley College, Reedley, CA 93654 \\ David Yun
}

Natural Resources Management Department, California Polytechnic State University, San Luis Obispo, CA 93407

Ulric Lund

Statistics Department, California Polytechnic State University, San Luis Obispo, CA 93407

Walter Mark

Natural Resources Management Department, California Polytechnic State University, San Luis Obispo, CA 93407

Douglas Piirto ${ }^{1}$

Natural Resources Management Department, California Polytechnic State University, San Luis Obispo, CA 93407

${ }^{1}$ Corresponding author: Dr. Douglas Piirto, Natural Resources Management Department, California Polytechnic State University, San Luis Obispo, CA 93407; Telephone: 805-756-6390; email: dpiirto@calpoly.edu. 


\section{Introduction}

Monterey pine (Pinus radiata D. Don) is one of the most widely exported and planted trees in the world. Yet, little is known about management techniques to sustain forest health and reproduction in the limited native stands that occur in California (Cope, 1993; Smith et al, 1997). The remaining five native stands that represent only a small portion of the historical range are considered to be a critical genetic resource. A variety of ecological (e.g., pitch canker disease) and anthropogenic factors (e.g., urban development, fragmentation) are affecting these native stands.

Three of the native stands are found along California's coast with the northern most the Año Nuevo stand reaching $37^{\circ} 8^{\prime} \mathrm{N}$, the southern most the Cambria population at $35^{\circ} 34^{\prime} \mathrm{N}$, and lying between is the Monterey Peninsula population (36³5’N) (Moulds, 1950; Forde, 1964). The other two stands are found on the Cedros and Guadalupe islands off the coast of Baja, Mexico (Libby et al, 1968). Due to the geographic division the trees of each stand are genetically distinct from each other (i.e. Mexican populations represent a variety (P. radiata D. Don var. binata auct. non (S. Watson) Lemmon) and comprise variability vital for the future of the species in the face of threatening factors (Deghi et al., 1995; Stuart \& Swayer, 2001)

Although Monterey pines are not used much domestically, other countries have grown to depend upon the unique qualities of the species. The rainfall and mild temperatures of the southern hemisphere have encouraged countries including Australia, New Zealand, Spain, Chile, Argentina, Uruguay, Kenya, and the Republic of South Africa to propagate the species for its rapid growth, desirable lumber, and pulp quality (McDonald and Laacke, 1990; Smith et al, 1997). As of 2002 these international populations had reached an estimated 4.1 million hectares, dwarfing the native range, which covers less than two-tenths of $1 \%$ of that amount (Rogers et al., 2002).

Monterey pines of California grow from sea level to elevations as high as $304.8 \mathrm{~m}\left(1,000^{\prime}\right)$ with varying development results (Roy, 1966; McDonald \& Laacke, 1990). In Mexico the populations range from 275-1,160m (900'-3805') in elevation (Libby et al, 1968). The native stands of the California coast have several climatic characteristics in common: humidity year round, absence of snow or hail, and 15-35" of annual rainfall with $75 \%$ of that precipitation falling between December and March (Offord, 1960). The native stands have not spread partly due to climatic and topographic (e.g. aspect) limitations. Decreased 
precipitation and lower winter temperatures of adjacent areas prove to be limiting factors. Monterey pines do best in soils that are described as medium to coarse textured and medium fertility with a $\mathrm{pH}$ range of 4.5 to 5.20. As soils become finer in texture, as with Diablo clay adobe soils, the species' development becomes poor or entirely gives way to grasslands (i.e. Cambria stand) (Moulds, 1950).

Monterey pine is one of the species included in the 'closed-cone pine' ecological group, which regenerate most successfully after a fire has burned through, exposing the mineral soil, killing the old crop, and opening cones to release seeds (Smith et al, 1997). However this process has been interrupted and dramatically reduced by fire suppression policy in the native stands (Stuart \& Sawyer, 2001). Additionally, at Año Nuevo broadleaf species and other common associates increasingly hamper regeneration by blocking the critical amount of light needed for the Monterey pine establishment (Piirto \& Valkonen, 2005). A cutting or fire treatment is necessary to counterbalance the aforementioned conditions, restoring an environment favorable for a sustained Monterey pine population (Piirto \& Valkonen, 2005).

Other challenges caused by urbanization additionally threaten the three native California stands. Urban development has impacted the native stands through fragmentation, increased stress, introduction of invasive weeds, and genetic contamination from exotically propagated landscape plantings of Monterey pine (White, 1999; Storer et al., 2001; Rogers, 2002; Piirto \& Valkonen, 2005).

One of the most notable consequences of urbanization was the introduction of the non-native pathogen Fusarium circinatum Nirenberg \& O’Donnell (=F. subglutinans f. sp. Pini J.C. Correll), commonly known as pitch canker (Dwinell, 1999). The exotic pitch canker infection of Monterey pine was first discovered in California's Santa Cruz County in 1986 and has since been a topic of discussion and research (McCain et al., 1987). The pathogen was found to be affecting in addition to Monterey pine a variety of species inclusive of Pinus muricata D. Don, P. coulteri D.Don,, P.ponderosa Laws., $P$. canariensis C.Smith, P. pinea Linnaeus, and P. halepensis Mill.. By 1992 the disease had been identified as far south as San Diego County and north into Mendocino County, as well as in each of the three native California stands (Storer et al., 1994). Along California, Monterey pines closer to the coast (within $1.5 \mathrm{~km}$ ) are at higher risk for infection and are prone to quick progression of symptom advancement (Wikler et al., 2003; Ganley et al., 2009). Models predict humid subtropical and Mediterranean climates, including portions of currently unaffected countries such as China, Australia, New Zealand, and Brazil, are optimal 
for establishment of the disease, stressing the importance of quarantine measures and the need for control techniques (Ganley et al., 2009). Insight into which factors impact the progression of incidence and subsequent disease symptoms is key to understanding the pathogen's behavior and ultimately developing management guidelines (Dallara et al., 1995).

The pathogen is caused by fungus Gibberella circinata Nirenberg \& O’Donnell, more commonly known by its conidial condition, Fusaruim circinatum Nirenberg \& O’Donnell. Conidia, the asexual, raindispersed spore is dependent upon wounds for infection to occur. Damage from natural growth, weather, pruning, and insects can all provide a site for the spore to attack (Harrington, 1998). Dissemination is also possible through infested seed (Ganley et al., 2009). Pitch canker is characterized in pines by stem death and necrosis of the interior woody tissue of shoots, branches, cones, exposed roots, and stem of the tree (Dwinell, 1999; Storer et al., undated). The needles of infected branch tips wilt, turn from yellow to red, and eventually die. Helpful in assessing the infection's status the dieback caused from these fallen tips will have a visual impact on the fullness of the canopy, Generally stem cankers (flattened, slightly sunken areas that seep copious amounts of resin; considered a sign of advanced infection) start to form following substantial dieback (Dallara et al., 1995). Once a stem canker develops, it can quickly girdle the tree's bole, causing top kill and eventually tree death (Storer et al, undated).

Currently the intricacies of the disease remain unclear. For example, it is speculated that infected individuals that do not experience more severe symptoms or do not die as a result of an advanced infection are expressing a genetic resistance to the disease. (Aegerter \& Gordon, 2006). Another belief that insect vectors affect infection is supported by successful isolations of the fungus from several species of bark and cone beetles, further reinforced by the appearance of symptoms aligning with behaviors and periods of increased activity for the aforementioned species (Storer et al., 1994; Gordon et al., 2001). Theories as such are being tested to gain the comprehension necessary to manage the disease (Gordon et al., 2001).

Another major pathogen affecting Monterey pine is Western gall rust (Endocronartium harknessii (J.P. Moore) Y. Hiratsuka), a fungal disease that affects two- and three-needled Pinus ssp. (EPPO, 2010). Detection of this 'pine-pine rust' (i.e. only a pine host is needed for disease's full life-cycle) has been identified in each of the three native California stands (Adams, 1997; Offord, 1964). Infecting the cambium, the disease can severely degrade growth and overall tree health, potentially proving fatal 
(Adams, 1997; OSU, 2010). Young trees are most susceptible to infection, easily succumbing to main stem infections (OSU, 2010). More mature trees experience branch infections that stunt growth and weaken structural integrity at infection site (Adams, 1997; OSU, 2010). Considering the ease of rapid intensification of this 'pine-pine' disease within a population, low proportions of western gall rust infection in native stands may indicate that either Monterey pines exhibit more resistance than other Pinus ssp. or the environment is not optimal for the fungus (Henry, 2005).

Regardless of the success experienced by plantations, the struggles outlined above present concern for the long-term resilience of the species. Conserving the native stands of Monterey pines and the genetic resources within could prove critical for protecting the future of foreign industry and for safeguarding processes of the native ecosystem against changing global demands (Deghi et al., 1995). This study addresses the need to develop an appropriate and effective science-based forest management program. Variables associated with uneven-aged forest management will be investigated to determine whether or not the silvicultural methods listed below can increase survival, improve growth of locally sourced planted seedlings, and discourage pitch canker infection. The hypotheses tested are as follows:

1. Monterey pine seedling survival is influenced by factors:
a) gap-size
b) site-treatment
c) parent tree

2. Monterey pine seedling a) height and b) diameter are significantly different due the factors (a-c) above.

3. Severity of pitch canker incidence and symptoms are influenced by factors (a-c) above.

Fifty acres of the native Año Nuevo Monterey pine stand, which lies on part of California Polytechnic State University Corporation (Cal Poly) property at Swanton Pacific Ranch has been utilized for the five-year study to achieve the goals mentioned above. This stand is perfectly suited as it provides an invaluable opportunity to focus upon the species in its native environment. The study was developed by Cal Poly graduate students and professor team from Cal Poly's Natural Resource Management Department, 
funding provided by Senate Bill 1712 (administered by CalFire) and California State University Agricultural Research Initiative (ARI).

\section{Materials and Methods}

The following outlines all procedures developed by Cal Poly State University Natural Resource Management Professors Dr. Douglas Piirto, Dr. Walter Mark, Dr. Samantha Gill, and Dr. Scott Stephens, in consultation with the Pitch Canker Task Force (PCTF) and other scientists researching pitch canker in California. The initial study design was implemented by an extensive team inclusive of Dr. Walter Mark, Dr. Douglas Piirto, individuals from Swanton Pacific Ranch, Big Creek Lumber, the United States Forest Service, along with Elicia Wise, David Yun, and 47 undergraduate assistants. Jason Pinkerton conducted the 24 month post-treatment survey and analysis, and Valerie Loe the 68 month post-treatment survey and analysis.

\subsection{Study Site}

The study site lies in the Scotts Creek Management Unit of Swanton Pacific Ranch at the southern end of the indigenous Año Nuevo stand. Differentiating it from the other two native stands in California, the Año Nuevo is the smallest with an estimated 400 to 600 hectares most of which (85\%) is privately owned and remains fairly undeveloped (Roger, 2002; Auten, pers. Comm., 2010). Containing 106 hectares, the management unit is comprised of two distinct aggregations including a Monterey pine concentration (22 hectares) (Wise, 2004). At the western end of the unit where the ground is fairly level with only few gentle slopes, Monterey pine grows in domination, and in some cases comprises $100 \%$ of the overstory (Piirto and Valkonen, 2005). Elsewhere in the unit Monterey pines grow among coast redwood (Sequoia sempervirens (D.Don) Endlicher), Douglas-fir (Pseudostuga menziesii (Mirbel) Franco), California nutmeg (Torreya californica Torrey), and a variety of broadleaf species, most notably coast live oak (Quercus agrifolia Nee) and Shreve oak (Quercus parvula var shrevei (C.H. Muller)) (Piirto and Valkonen, 2005; Auten, pers. comm., 2010).

With a mean annual precipitation of 30.67 inches and a mean annual temperature right around $57^{\circ}$ (daytime high being $68^{\circ}$ and the nighttime low being $46^{\circ}$ ) Santa Cruz County is considered Mediterranean 
in climate (USDC, 2004; CPSU, 2007). A combination of summer fogs, an average humidity between 70$80 \%$ in winter, and overcast skies accounting for $30-40 \%$ of daylight hours annually, translates into reduced solar energy received by vegetation (CPSU, 2007).

In 2005 pitch canker incidence within the unit was 35.3\% (SE 3.5), making it the highest of the three native stands (Henry, 2005). Yet these numbers indicate a decrease in disease incidence from several years earlier (1999) when an estimated $90 \%$ of trees $(\mathrm{d}>2.54 \mathrm{~cm})$ were symptomatic (Piirto \& Valkonen, 2005). Death of infected trees may account for this drop in recorded incidence. Moreover, this decrease in occurrence may lend support that a range of susceptibility exists where trees previously recorded as infected were able to resist disease advancement and eliminate symptoms (e.g. overgrowth of branch tips, dropping of infected branches) (Gordon et. al, 2006). Needless to say, pitch canker has heavily impacted the Scott's Creek Management Unit in the 10 or so years since original confirmation of the disease in Año Nuevo in 1992 and warrants scientific study (Storer et al., 1994).

\subsection{Experimental Design}

The field-design entails three replications of 9 plots (total of 27), which represent three gap-sizes, two site-treatments and one control (Wise, 2004). The circular plots are $0.20-, 0.10$-, or 0.05 -hectare in size (Table 1) (Wise, 2004). Plots chosen for group-selection harvesting were treated with one of two preparation-methods: lop and scatter or pile and burn. Produced were 18 treated gap openings and 9 control plots. Control plots remained untreated; no trees were cut, no preparation method was performed, and no seedlings were planted. These plots will serve as a constant for long-term survey of natural regeneration and understory vegetation. Note that gap will refer to only the treated openings whereas plot refers to all 27 plots. Likewise the term study area refers to all plots, treated or control. The plot location and designation of treatment were chosen in a random and unbiased fashion. All plots are located within pure stands of the Monterey pine aggregation at Swanton Pacific Ranch. Please note that a review of soil types was executed, however the results were not statistically analyzed for effect upon dependent variables. Please refer to Wise (2004) for information regarding soil composition within each plot. 
Table 1. Radius and area of study plots. Source: Wise, 2004

\begin{tabular}{|c|c|c|c|c|c|c|}
\hline $\begin{array}{c}\text { Plot } \\
\text { size }\end{array}$ & \multicolumn{2}{|c|}{0.20 -hectare } & \multicolumn{2}{c|}{0.10 -hectare } & \multicolumn{2}{c|}{ 0.05-hectare } \\
\hline Units & English & Metric & English & Metric & English & Metric \\
Radius & $83.26 \mathrm{ft}$ & $25.37 \mathrm{~m}$ & $58.87 \mathrm{ft}$ & $17.94 \mathrm{~m}$ & $41.63 \mathrm{ft}$ & $12.68 \mathrm{~m}$ \\
Area & $21,780 \mathrm{ft}^{2}$ & $2,023 \mathrm{~m}^{2}$ & $10,890 \mathrm{ft}^{2}$ & $1,011 \mathrm{~m}^{2}$ & $5,445 \mathrm{ft}^{2}$ & $506 \mathrm{~m}^{2}$ \\
\hline
\end{tabular}

\subsection{Field Procedures}

\section{Plot Location}

The following is a summary of the procedures followed by Wise, Yun, Mark, Piirto and crew for gap creation, preparation methods, and reforestation. Refer to Wise (2004) for a thorough description of each process. In summation, Arc View GIS was used to randomly locate plots and designate site-treatment and gap-size within the study area. Each plot was subsequently ground-truthed to ensure the following requirements were satisfied:

-Slope less than $35 \%$ (tractor accessible)

-Located within the Monterey pine aggregation (suitable MP habitat)

-Minimum $100 \mathrm{ft} .(30.5 \mathrm{~m})$ buffer between adjacent plots

-Consideration of residual stand features (i.e. maintain wildlife trees, avoid areas

with known concentration of root rot (Armillaria) and areas of problematic erosion).

-Adhere to California regulations (CDF, 2010) for watercourse and lake protection zones

$-100 \mathrm{ft}(30.5 \mathrm{~m})$ minimum slope distance from class II watercourse.

-Out of class II ponds.

-No less than $50 \mathrm{ft}$ (15.24 m) slope distance from class III watercourse.

\section{Gap Creation and Site Preparation}

During the late summer and early fall of 2001, trees within the 18 group-selection plots were felled and bucked (stems being tractor yarded to a nearby landing for later on-site milling). Following opening of the gaps, one of the two preparation methods was applied. Remaining biomass in the lop and 
scatter plots was cut into $<1.1 \mathrm{~m}$ sections and distributed throughout the unit to create a layer of slash no more than $45.7 \mathrm{~cm}$ deep. Remaining biomass in the pile and burn plots was gathered into a central pile and burned (January 2002). Burn remnants were distributed throughout the unit before planting (Wise, 2004).

\section{Reforestation}

After creation of the gaps, each was reforested with seedlings generated from seeds collected from thirteen mother (parent) trees from the Año Nuevo stand. In October 2000, seeds from the 1998 crop of Monterey pine were gathered from trees already existing in the study area as well as trees on the Big Creek Lumber Company's portion of the native stand. Mother trees were tested for resistance to pitch canker using methods outlined by Gordon et al. (1998) (see resulting rankings from resistance testing in Table 2). In attempt to provide a variety of expressed resistance, the thirteen parents chosen for use in the study were selected based on the results of the screening process. Please note that mother tree is the only control for parent since the seeds were product of open pollination.

Table 2. Seedling resistance rating by parent as determined by screening of original parent trees in June 1999 and June 2000. Source: Pinkerton, 2006

\begin{tabular}{|c|c|c|c|}
\hline & \multicolumn{3}{|c|}{ Rating } \\
\cline { 2 - 4 } & Resistant & Intermediate & Susceptible \\
\hline \multirow{3}{*}{} & BC6 & BC3 & BC4 \\
¿. & BC11 & BC13 & SP15 \\
& BC12 & SP3 & SP1 \\
& SP2 & SP5 & SP4 \\
\hline
\end{tabular}

The respective parent identifies each seedling in the study. The letters in parent-monikers are derived from source location: SP\# signifies a tree sourced from Swanton Pacific Ranch whereas BC\# signifies a tree from Big Creek Lumber. Each of the 13 parents constitutes roughly $7 \%$ of the seedlings in each gap. Refer to Table 3 and Wise (2004) for additional information regarding number of seedlings by parent in each gap. After screening, seeds were sown at Cal Poly in May 2001 and transported to a shadehouse at Swanton Pacific Ranch in August 2001. In February 2002 the trees were out-planted into treated 
plots in accordance with the systemized random pattern outlined by Wise (2004). A total of 2,280 trees were planted at $3 \mathrm{~m}$ by $3 \mathrm{~m}$ spacing, resulting in 1,074 trees per hectare. Several hundred additional trees were saved for future reforestation needs (Pinkerton, 2006). Refer to Pinkerton (2006), Appendix B for individual plot details inclusive of original and interplanted seedling parents and locations.

Table 3. Number of seedlings planted per gap and parent. Source: Wise, 2004

\begin{tabular}{|c|c|c|}
\hline Gap size & $\begin{array}{c}\text { Total \# of } \\
\text { seedlings }\end{array}$ & $\begin{array}{c}\text { Seedlings / } \\
\text { parent/gap }\end{array}$ \\
\hline 0.05 -hectare & 52 & 4 \\
0.10 -hectare & 112 & 8 or $9 *$ \\
0.20 -hectare & 216 & 16 or $17^{*}$ \\
\hline
\end{tabular}

*Differed due to total number of trees/plot not evenly divisible by number of parent trees (13)

\section{Interplanting}

By the 12-month data collection, $673(29.5 \%)$ of the 2,280 original trees were missing (Pinkerton, 2006). The consequent empty tree spaces were determined as detrimental to the outcome of the original experiment design and thus trees saved for reforestation from the original greenhouse plantings were used to fill in. Resulting are two sub-categories of planted seedlings: original (trees sustained from the 2002 planting) and interplanted (trees planted in February 2003). Please refer to Table 4 for number of interplanted trees by parent. Due to limited reserves, seedlings from only 8 parent trees were used for interplanting.

Table 4. Number of interplanted seedlings by parent. Source: Pinkerton, 2006

\begin{tabular}{|c|c|}
\hline Parent Id. & Number Planted \\
\hline 2BC3 & 34 \\
2BC6 & 151 \\
2BC11 & 139 \\
2BC12 & 48 \\
2BC13 & 43 \\
2SP2 & 150 \\
2SP5 & 54 \\
2SP6 & 54 \\
\hline TOTAL & 673 \\
\hline
\end{tabular}




\subsection{Data Collection and Analyses}

To describe the general condition of the study site prior to treatment, an inventory was conducted to determine tree size, density, and degree of damage and disease infestation of all plots. Inventory data included: diameter at breast height (1.37m), damage (e.g. crooks, bends, forked tops, etc.), and presence of disease signs/symptoms for all trees with a diameter greater than $2.54 \mathrm{~cm}$. Evidence and severity of pitch canker infection was the main concern, however detection of other pathogens (e.g. western gall rust (Endocronartium harknessii (J.P. Moore) Y. Hiratsuka [=Peridermium harknesii J.P. Moore] and Armillaria mellea ([Vahl.:Fr.] Karst)) were also noted. Understory vegetation and natural regeneration survey were conducted to determine a baseline for ongoing studies and shed further insight on subsequent post-treatment development (Wise, 2004).

In treated gaps, artificially regenerated seedlings will be assessed for several factors (i) survival (both original and interplanted seedlings), (ii) height (mm), (iii) diameter (mm), (iv) pitch canker symptoms, and (v) western gall rust symptoms. All plots will be assessed for (i) ocular estimate of understory density and composition, (ii) natural regeneration, and (iii) vegetation progression. Photo points were used to observe the latter feature and make visual record of gap development. After collection, data was compiled, and when appropriate, analyzed statistically. The three survey periods (i.e. approximately 12-, 24- and 68- months post-planting) followed uniform collection methods where possible to ensure consistency. Any deviations or dissimilar methods will be noted in the following text.

To help understand the impact of silvicultural treatment, understory vegetation data was collected and analyzed with descriptive statistics. Each plot was visually divided into quadrants with division lines determined by use of a Silva hand compass at the four cardinal directions (e.g. north, south, east, and west). Vegetation cover was ocularly estimated (to a sum of 100\%) for each of the four subplots. The data from the four subplots were averaged to estimate vegetation cover (to 100\%) for the whole plot. Ensuing averages created for site-treatment by gap-size were used to create charts for elemental comparison. Major species were recorded as well as areas of no vegetation (e.g. bare ground or leaf/needle litter). Most vegetation types detected were identified to species level however, for ease of subsequent analysis, some were only identified to family level (e.g. grasses, rushes, sedges, and ferns). 
At pre-treatment, post-treatment 12- and 24- month collection periods, micro sites were created to estimate the number of naturally occurring seedlings (both residual pre-treatment seedlings and newly recruited post-treatment seedlings) at the understory level. The micro site sample method entailed subplots (two square meters in dimension) systematically laid out along lines radiating from plot center. The amount of lines increase as gap-size enlarges. 0.05-hectare plots have four lines (at each cardinal direction), 0.10 -hectare plots have lines every $45^{\circ}$, and 0.20 -hectare plots, every $22^{\circ}$. Three subplots were evenly spaced along each line, translating to a total of 13 subplots in $0.05-, 25$ subplots in $0.10-$, and 52 subplots in 0.20 -hectare plots. Resulting is approximately a $10 \%$ sample. At 68 months post-treatment, a $100 \%$ survey was conducted in all gaps to accurately count naturally occurring regeneration Monterey pines.

For survival assessment, all trees were carefully identified and recorded as surviving or dead. Dead trees are defined as having no living needles (e.g. no green needles). If a tree death was observed, a red "X" was used for in-field records. In-field data was then transferred into digital database using a " 0 " for dead trees and " 1 " for surviving trees. Missing trees (i.e. no tree found at planting location) were considered dead.

Growth data (height and diameter) was collected for a random $25 \%$ sample of original trees. The same trees were measured for each of the three data collection periods (Table 5). Height measurements were taken at the tip of the apical meristem or the top of the living tissue if the tree's top growth was dead or dying. New, dominating meristems were measured in instances where treetops had died, fallen off, and had been replaced by production of new tissue. In cases of forked tops, the taller of the two was measured. Diameter measurements were taken at soil level.

Table 5. Number of sample seedlings planted by parent and gap for all 18 treated gaps. Source: Wise, 2004

\begin{tabular}{|c|c|c|c|}
\hline Gap size & \#/parent/gap & $\begin{array}{c}\text { Total/gap } \\
\text { (all parents) }\end{array}$ & $\begin{array}{c}\text { Total (all gaps, } \\
\text { all parents) }\end{array}$ \\
\hline 0.05-hectare & 1 & 13 & 78 \\
0.10-hectare & 2 & 26 & 156 \\
0.20-hectare & 4 & 52 & 312 \\
\hline Total & & & 546 \\
\hline
\end{tabular}


Original trees were analyzed with descriptive and inferential statistics for overall data as well as by gap-size, site treatment, and parent. SPSS and SAS statistical software were used to analyze primary outcome variables of seedling height $(\mathrm{cm})$, diameter $(\mathrm{mm})$, and survival at 68 months post-planting. Survival of artificially regenerated seedlings will be analyzed for all 2,280 trees. Growth of artificially regenerated seedlings will be analyzed for the 271 surviving individuals of the original 546 sample trees. Descriptive statistics will include range, mean and standard deviations (SD) for height and diameter. Please note interplanted seedlings will be analyzed separately using only descriptive statistics, presented in Loe (2010).

Inferential analysis of survival and growth data according to site-preparation, gap size, and seedling parent will utilize PROC MIXED in SAS v.9.1. Mixed effect models were used to account for the potential correlation between the observed unit (individual trees) within the experimental unit (gaps) (Lund, 2007). For a more developed description of PROC MIXED the reader is referred to U. Lund's Technical Report (2007) or to McCulloch \& Searle (2001). Although the aforementioned analyses will be for data collected at 68 months, accompanying figures will include growth and survival data from each of the three data collection periods $(12,24-$ and 68 - months post-treatment).

All 2,280 trees were assessed for pitch canker and western gall rust symptoms. Each tree was observed from all angles to accurately tally the number of symptomatic branch tips, stem or branch cankers, and stem or branch galls. Disease results will be analyzed with descriptive statistics for overall data as well as by gap-size, site-treatment, and parent. Contingency tables were used to investigate the relationships between silvicultural variables and disease incidence.

Lastly, we utilized survival and growth results to infer whether differences in sun exposure, caused from the sun's geographic position and locality of the individual trees within the gap, affected survival and growth rates. We chose six days that could feasibly influence either the survival or growth of Monterey pine. August 1, 2003 was chosen as it falls at the end of summer when drought conditions can reduce vigor, increase stress, and increase the likelihood of pest and disease attack, all of which could possibly raise mortality rates. May 1, 2003 was chosen as it falls in the midst of spring when Monterey pines usually experience a period of growth (Mark, pers. comm., 2009). The dates of vernal and autumnal equinoxes as well the summer and winter solstices of 2003 were also chosen for the sun's extreme 
positions. The gaps were quartered and aligned so that the sun's azimuth at noon (12:00 p.m.) bisected one of the quadrants (labeled 'Quarter 1'). The remaining three quadrants ( $90^{\circ}$ sections) were numbered in sequential order, clockwise. Averages for survival rate and growth (height) from 24 months post-treatment were determined for each of the quadrants then compared to conclude whether an observable pattern exists. The same process was used for each of the six days.

\section{RESULTS}

\subsection{Pre-treatment Conditions}

The study area's overstory was composed of $54 \%$ conifer species and $46 \%$ hardwoods.

Dominating were Monterey pine (44\% of the overstory), and a combination of coast live and Shreve's oak (collectively $34 \%$ of the overstory) (Wise, 2004). Species represented in lesser amounts include Douglasfir, big-leaf maple (Acer macrophyllum Pursh), California bay (Umbellularia californica (Hook. \& Arn.) Nutt.), California buckeye (Aesculus californica (Spach) Nutt.), California, and Pacific madrone (Arbutus menziesii Pursh) (Wise, 2004).

Of the 575 living Monterey pine surveyed pre-treatment, $75 \%$ had a diameter less than $51 \mathrm{~cm}$. This indicates a large number of pole-sized trees and only few larger individuals within the study area. Overall, diameter measures ranged $188 \mathrm{~cm}$, averaged at $30.5 \mathrm{~cm}$, and had a SD of $33 \mathrm{~cm}$. Density measures ranged from 148 to 1165 trees per hectare, averaged at 411 trees per hectare. Basal area for all tree species was approximately $49 \mathrm{~m}^{2} / \mathrm{ha}$, of which $27.5 \mathrm{~m}^{2} /$ ha was Monterey pine. The remainder was chiefly occupied by Douglas-fir and live oak species (Wise, 2004).

Damage appraisal of all 709 surveyed conifer trees showed that $16.8 \%$ (119) had some degree of damage, inclusive of such traits as dead tops (not associated with pitch canker), crooks, bends, suppression, bole or branch damage (mechanical, animal or unknown). Disease appraisal showed that the two most frequently occurring pathogens were pitch canker and western gall rust. Of the 575 Monterey pines surveyed pre-treatment, $34.6 \%$ (189) were deemed symptom free, $65.4 \%$ (365) appeared to have some level of pitch canker infection, and 10.8\% (59) showed signs of western gall rust. Pitch canker symptoms ranged from branch flags to resinous cankers and top kill. $14 \%$ of the infected individuals had multiple symptoms such as branch flags and stem cankers (Wise, 2004). 


\subsection{Understory Vegetation}

Prior to treatment the study site had a fairly homogenized mix of species (See Table 6 for predominant species detected), comprised of poison oak (24\%), California blackberry (21\%), 'other species' (15\%), leaving $40 \%$ unvegetated. Please note the 'other species' are those that represent less than $5 \%$ of the total area at the size or treatment level (Wise, 2004). By 24 month post-treatment, the two most significant changes were the appearance of annual weedy species (e.g. grasses and thistles that were not found in the study site prior to treatment), and an increase in overall species diversity (Pinkerton, 2006).

By 68 months post-treatment, the cover of grass and thistle tapered from the peaks seen in previous surveys. Similarly, there was a drop in unvegetated areas and California blackberry occurrence. The decrease in these categories was counterbalanced by an increase of poison oak and 'other species'. The increase Wise and Pinkerton observed in species diversity was more dramatically expressed in all plots by 68 months. Figure 1 represents the understory vegetation trends for overall study site (inclusive of all 27 plots: pile and burn, lop and scatter, and control). Table 6, lists notable plant species found within the plots.

\section{Understory Vegetation: Study Area}

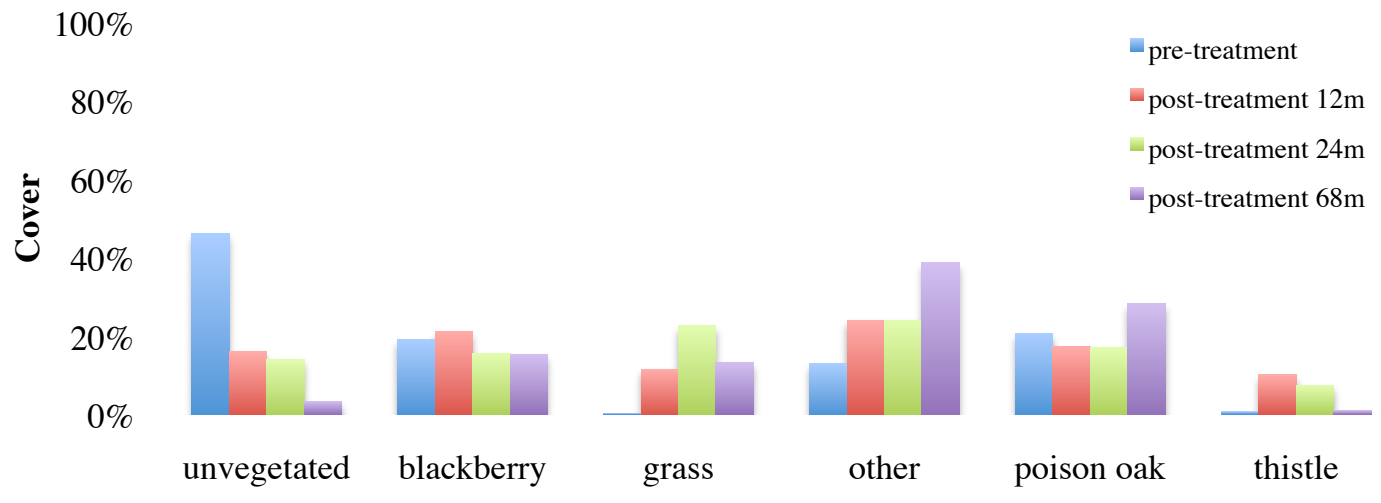

Figure 1. Summary of understory vegetation cover (\%) for study site at pre-, post-treatment $12,24 \& 68 \mathrm{~m}$ post-treatment. Source: $12 \mathrm{~m}$ data: Wise, 2004; $24 \mathrm{~m}$ data: Pinkerton, 2006; 68m data: Loe.

Understory vegetation in control plots at 68 months was dominated by poison oak and 'other species', staying fairly consistent with surveys from 12- and 24-months post-treatment. California blackberry maintained presence but decreased by about half in all plot sizes. 
In pile and burn plots 68 months post-treatment, poison oak and 'other species' dominated. Both categories showed increased cover since 12- and 24-month surveys. California blackberry and grasses accounted for substantial amounts of cover, coming back from a lull seen at 24 months yet not reaching the peak percentages seen at 12 months.

Much like the other plots in the study, lop and scatter gaps 68 months post-treatment were predominately vegetated by poison oak, 'other species', California blackberry, and grasses. Understory in 0.10-hectare gaps is most strongly dominated by poison oak whereas both 0.20 - and 0.05 -hectare gaps have a more even distribution of above-named species/categories.

In addition to herbaceous species, naturally occurring seedlings at understory level were counted in sample-micro sites during pre-treatment, 12- and 24- month post-treatment surveys. Pre-treatment natural regeneration seedlings were comprised of $79 \%$ hardwood and $21 \%$ conifer species (57\% Monterey pine, $43 \%$ Douglas-fir). Similarly, at post-treatment 12 months, $78 \%$ were hardwoods and $22 \%$ conifers (Wise, 2004). Yet by post-treatment 24 months we see that hardwood seedlings only account for $58 \%$ of naturally regenerated seedlings, resulting in a growing percentage of conifer species (42\%). Of the $42 \%$ softwoods seedlings, $91 \%$ were Monterey pine and 9\% were Douglas-fir, indicating a dramatic change from the proportions recorded during pre-treatment survey (Pinkerton, 2006). A 100\% survey of naturally regenerated Monterey pine seedlings at 68 months will be addressed below. 
Table 6. Predominant under- and over-story species observed within the study site.

\begin{tabular}{|c|c|c|}
\hline \multicolumn{3}{|c|}{ Conifer species } \\
\hline $\mathbf{s p}$ & & \\
\hline code & Botanical name & Common name \\
\hline $\mathrm{PiRa}$ & Pinus radiata D.Don & Monterey pine \\
\hline PsMe & Pseudostuga menziesii (Mirbel) Franco var. menziesii & Douglas-fir \\
\hline $\mathrm{ToCa}$ & Torreya californica Torrey & California nutmeg \\
\hline \multicolumn{3}{|c|}{ Hardwood species } \\
\hline sp & & \\
\hline code & Botanical name & Common name \\
\hline AcMa & Acer macrophyllum Pursh & big-leaf maple \\
\hline $\mathrm{AeCa}$ & Aesculus californica (Spach) Nutt. & California buckeye \\
\hline ArMe & Arbutus menziesii Pursh & Pacific madrone \\
\hline QuAg & Quercus agrifolia $\mathrm{Nee}$ & coast live oak \\
\hline QuSh & Quercus parvula var. shrevei (C.H. Muller) K. Nixon & Shreve's oak \\
\hline $\mathrm{UmCa}$ & Umbellularia californica (Hook \& Arn.) Nutt. & California bay \\
\hline \multicolumn{3}{|c|}{ 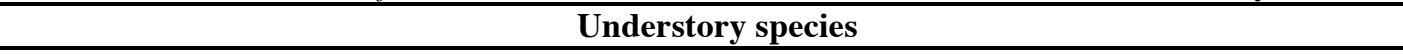 } \\
\hline sp & & \\
\hline code & Botanical name & Common name \\
\hline $\mathrm{BaPi}$ & Baccharis pilularis DC. & coyote bush \\
\hline $\mathrm{CeTh}$ & Ceonothus thyrsiflorus Eschsch. & blue blossom \\
\hline $\mathrm{CiVu}$ & Cirsium vulgare (Savi) Ten. & bull thistle \\
\hline $\mathrm{ClPe}$ & Claytonia perfoliata Willd. & miner's lettuce \\
\hline $\mathrm{CoCo}$ & Corylus cornuta Marsh var. californica (A. DC.) W. Sharp & California hazelnut \\
\hline CoMa & Conium maculatum $\mathrm{L}$. & poison hemlock \\
\hline DrAr & Dryopteris arguta (Kaulf.) Maxon & coastal wood fern \\
\hline ErMi & Erechtites minima (Poiret) DC. & burnweed \\
\hline $\mathrm{FrCa}$ & Fragaria vesca L. ssp. californica (Cham. \& Schldl.) Staudt & wood strawberry \\
\hline Ga sp. & Galium sp. & bedstraw \\
\hline $\mathrm{GnLu}$ & Gnaphalium luteo-album L. & cudweed \\
\hline IrDo & Iris douglasiana Herbert & mountain iris \\
\hline LoHi & Lonicera hispidula Douglas var. vacillans A. Gray & California honeysuckle \\
\hline MaOr & Marah oreganus (Torrey \& A. Gray) Howell & coast manroot \\
\hline $\mathrm{MiAu}$ & Mimulus aurantiacus Curtis & sticky monkey flower \\
\hline $\mathrm{NaSq}$ & Navarretia squarrosa (Eschsch.) Hook \& Arn. & skunkweed \\
\hline PoMu & Polystichum munitum (Kaulf.) C. Presl & sword fern \\
\hline PtAq & Pteridium aquilinum (L.) Kuhn var. pubescens L. Underw. & bracken \\
\hline $\mathrm{RhCa}$ & Frangula californica (Eschsch.) A. Gray & coffee berry \\
\hline $\operatorname{RiSp}$ & Ribes speciosum Pursh & $\begin{array}{l}\text { fuschia flowering } \\
\text { gooseberry }\end{array}$ \\
\hline RuUr & Rubus ursinus Cham. \& Schldl. & California blackberry \\
\hline $\mathrm{SaMe}$ & Sambucus nigra L. subsp. caerulea (Raf.) Bolli & blue elderberry \\
\hline SiMa & Silybum marianum (L.) Gaertner & milk thistle \\
\hline $\mathrm{SmRa}$ & Smilacina racemosa (L.) Link & false soloman's seal \\
\hline $\mathrm{StBu}$ & Stachys bullata Benth. & hedge nettle \\
\hline SyAl & $\begin{array}{l}\text { Symphoricarpos ablus (L.) S.F. Blake var. laevigatus (Fernald) } \\
\text { S.F. Blake }\end{array}$ & common snowberry \\
\hline ToAr & Torilis arvensis (Hudson) Link & hedge parsley \\
\hline ToDi & Toxicodendron diversilobum (Torrey \& A. Gray) E. Greene & western poison oak \\
\hline UrDi & $\begin{array}{l}\text { Urtica dioica (L.) ssp. holsericea (Nutt.) Thorne } \\
\text { Source: Wise, 2004; UCB, } 2010\end{array}$ & stinging nettle \\
\hline
\end{tabular}




\subsection{Natural Regeneration}

Vegetation sampling, used for all but the post-treatment 68-month survey, allowed for observation of spatial relationship to natural regeneration success. Subsequently seedlings were categorized as being located in inner, middle or outer rings of the circular gap. The post-treatment 24-month survey concluded that Monterey pine natural regeneration were distributed as follows: 13\% (inner), 23\% (middle), and 64\% (outer). The highest percentage of the 69 new recruitments was produced in the 0.05 -hectare pile and burn gaps (42\%) (Pinkerton, 2006).

At 68 months post-treatment, $100 \%$ survey concluded that the count of naturally regenerated Monterey pine seedlings had reached 159 (refer to Table 7). By gap-size, 19 (42 trees/ha) were in 0.05-, 74 (82 trees/ha) in 0.10-, and 66 (36.7 trees/ha) in 0.20-hectare gaps. By treatment, of the overall 159 natural regeneration seedlings, 75 (71 trees/ha) were in pile and burn gaps, leaving 69 (65 trees/ha) in the lop and scatter gaps and a mere 15 (14 trees/ha) in control (no treatment) plots. The highest percentage of new recruitments was produced in the 0.10 -hectare pile and burn gaps $(22 \%)$.

Table 7. Summary of natural regeneration trees by treatment and gapsize at 68 months post-treatment.

\begin{tabular}{|c|c|c|c|}
\hline Treatment: & \#Seedlings & \% of total & Trees/Hectare \\
\hline Pile \& Burn & 75 & 47.2 & 71.6 \\
Lop \& Scatter & 69 & 43.4 & 65.9 \\
Control & 15 & 9.4 & 14.3 \\
\hline Size: & & & \\
\hline 0.05 ha & 19 & 12 & 42.2 \\
0.10 ha & 74 & 46.5 & 82.2 \\
0.20 ha & 66 & 41.5 & 36.7 \\
\hline Total: & 159 & & 50.5 \\
\hline
\end{tabular}

\subsection{Survival of Artificially Regenerated Seedlings}

Figure 2 shows the progression and comparison of the survival rates for all 2,280 seedlings over the study period. It is important to note that at 3-months post-treatment nearly all the seedlings were alive, eliminating the concern that poor planting technique is accountable for seedling mortality. We can see that pile and burn plots have a higher survival rate, which remained consistent through the duration of the study. Interestingly, the gap size survival rates have made a swap in rank. At 12- and 24-months, the 0.05-hectare 
gaps had the highest survival rate, followed by 0.20 -hectare, leaving the 0.10 -hectare plots with the lowest average survival rate. Conversely, by 68 months post-treatment we see that 0.10 -hectare gaps reached first rank, followed by 0.20 -hectare, leaving the 0.05 -hectare plots with the lowest average survival rate. However all three averages are still fairly clustered, pulling in the divergence seen at 12-months posttreatment. Parent survival rates vary considerably with one (SP15) parent consistently producing the lowest survival rate.

The survival rates of all 2,280 planted seedlings are presented in Table 8. Pile and burn gaps have a survival rate of $54.56 \%$, higher than the $43.68 \%$ of the lop and scatter gaps. We see a less dramatic spread between the gap-size survival rates. With a survival rate of $50.45 \%$, the seedlings in 0.10 -hectare gaps have an advantage over 0.20 -hectare's rate of $48.69 \%$ and 0.05 -hectare's rate of $48.08 \%$. Survival rates for the 13 parent trees span from $26.67-62.2 \%$. When deconstructed differently to observe the rates when site-treatment and gap-size are considered in unison, 0.20-hectare, pile and burn gaps have the highest rate $(56 \%)$ (see Table 9$)$. 
100

80

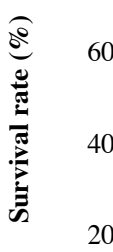

0

2/1/02
2/1/03

2/1/04

2/1/05

2/1/06

Time (2002-2007)

$\mathrm{P} \& \mathrm{~B}$

L\&S

Survival \% for 12m, 24m and 68m post-treatment by Gap Size

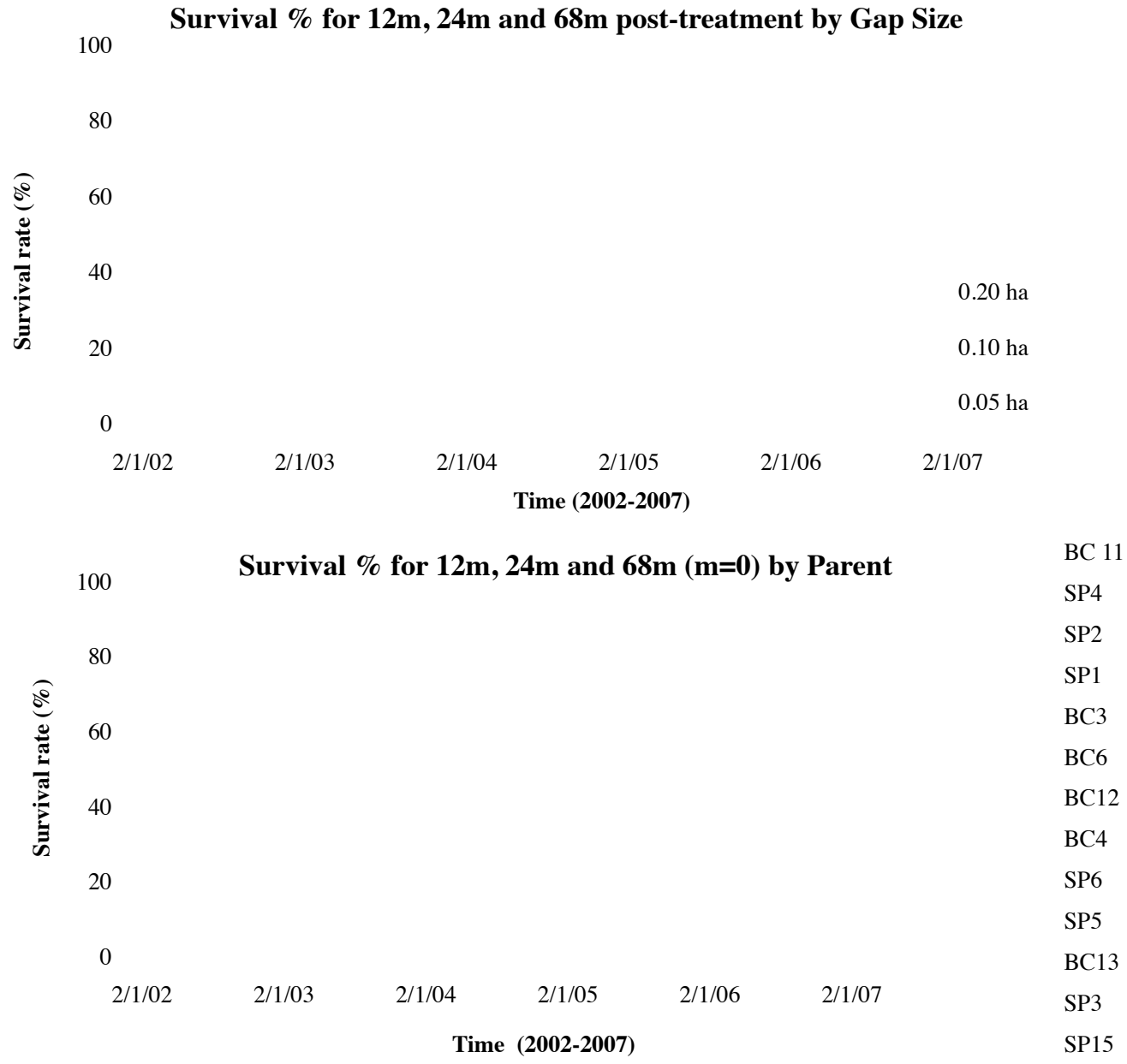

Figure 2. Illustration of survival rates $(\%)$ of all original seedlings at $68 \mathrm{~m}$ post-treatment by treatment, gap size, and parent. Source: $12 \mathrm{~m}$ data: Wise, 2004; 24m data: Pinkerton, 2006; 68m data:Loe. 
Table 8. Survival rate, by parent, gap size and treatment independently (68m post-treatment).

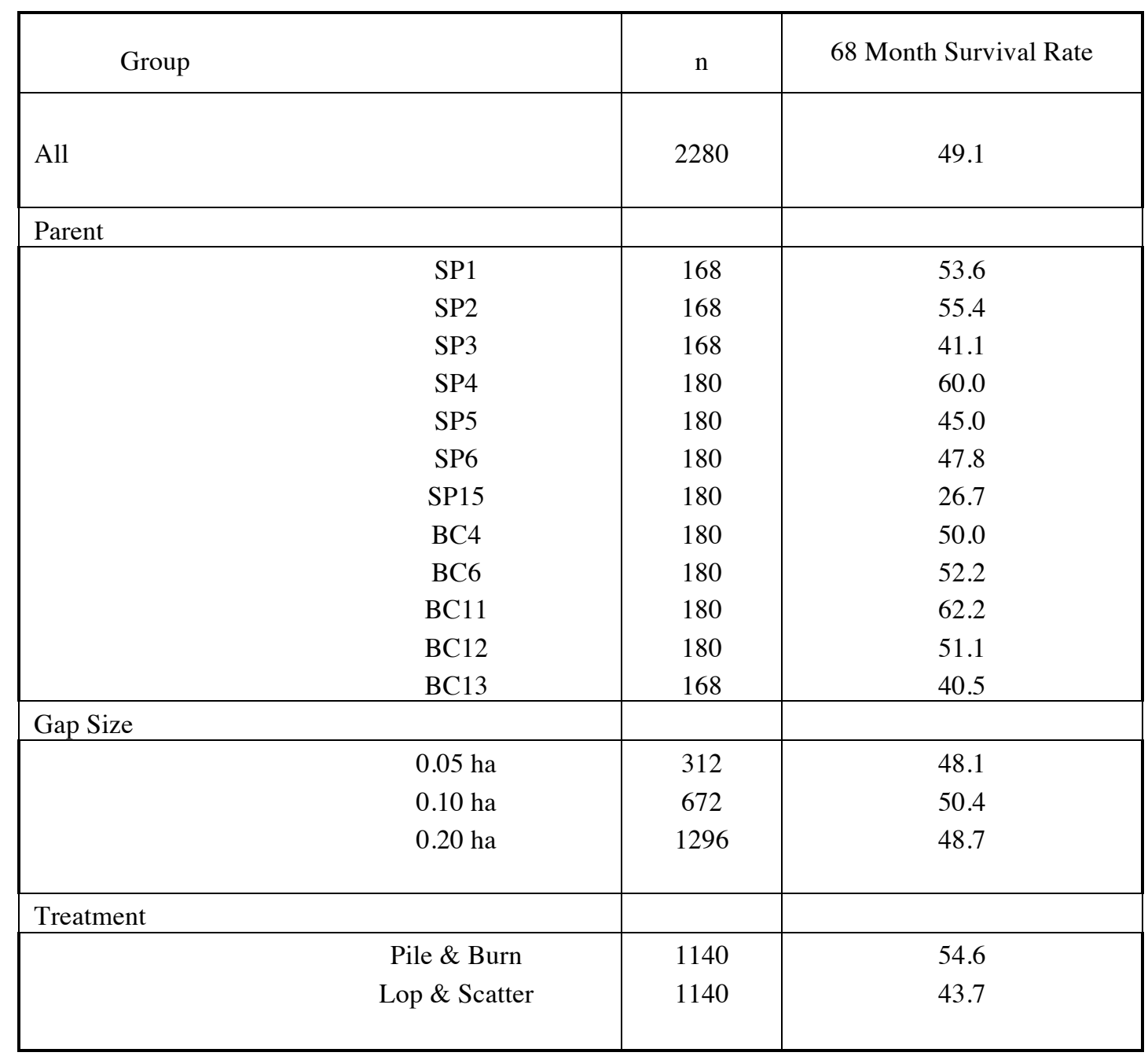

Table 9. Survival \# and rate by gap-size and treatment in unison at post-treatment 12-, 24-, and 68m post-treatment. Source: 12m data: Wise, 2004; 24m data: Pinkerton, 2006; 68m data: Loe.

\begin{tabular}{|c|c|c|c|c|c|c|c|}
\hline \multirow[b]{2}{*}{ Gap Size } & \multirow[b]{2}{*}{ Treatment* } & \multicolumn{2}{|c|}{ February (2003) } & \multicolumn{2}{|c|}{ February (2004) } & \multicolumn{2}{|c|}{ October (2007) } \\
\hline & & \#Seedlings & $\begin{array}{c}\% \\
\text { Surv }\end{array}$ & \#Seedlings & $\begin{array}{c}\% \\
\text { Surv }\end{array}$ & \#Seedlings & $\begin{array}{c}\% \\
\text { Surv }\end{array}$ \\
\hline \multirow{2}{*}{0.05 ha } & $\mathrm{LS}$ & 107 & 68.6 & 88 & 56.4 & 65 & 42.0 \\
\hline & PB & 122 & 76.9 & 103 & 66.0 & 85 & 54.0 \\
\hline \multirow{2}{*}{0.10 ha } & LS & 215 & 63.7 & 178 & 52.0 & 165 & 49.0 \\
\hline & PB & 220 & 65.5 & 190 & 56.6 & 174 & 52.0 \\
\hline \multirow{2}{*}{0.20 ha } & LS & 437 & 67.6 & 334 & 51.7 & 268 & 41.0 \\
\hline & $\mathrm{PB}$ & 502 & 76.9 & 399 & 61.6 & 363 & 56.0 \\
\hline Total & & 1603 & & 1292 & & 1119 & \\
\hline
\end{tabular}

* Treatment: LS is Lop \& Scatter and PB is Pile \& Burn 
The results from the mixed model prediction of the log-odds of seedling survival at 68 months post-treatment are presented in Table 10. The model detects that treatment has a moderate effect on survival. The odds of pile and burn gaps increase by $51.7 \%$ over those of lop and scatter gaps $(\mathrm{OR}=1.517$; $95 \% \mathrm{CI}=(0.970-2.373)$ with moderate statistical significance $(\mathrm{p}$-value $=0.0660)$. Neither the log-odds model nor a Tukey's pair wise comparison concludes any effect of gap-size on seedling survival (pvalues $=0.9362$ and 0.8035 for 0.05 - and 0.10 - acre relationship to 0.20 -hectare reference group).

Table 10. Coefficients and odds ratio for fixed effects in model predicting survival in 68m posttreatment.

\begin{tabular}{|c|c|c|c|c|c|c|c|}
\hline Effect & Estimate & SE & DF & t Value & $\operatorname{Pr}>|t|$ & OR & $95 \% \mathrm{CI}$ \\
\hline Intercept & -0.2667 & 0.2258 & 21.28 & -1.18 & 0.2506 & & \\
\hline \multicolumn{8}{|l|}{ Treatment: } \\
\hline Pile \& Burn & 0.4167 & 0.2130 & 18.06 & 1.96 & 0.0660 & 1.517 & $(0.970-2.373)$ \\
\hline Lop \& Scatter (Ref) & 0 & 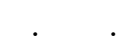 & 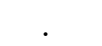 & & & & \\
\hline \multicolumn{8}{|l|}{ Gap Size: } \\
\hline Eighth & -0.02144 & 0.2646 & 19.8 & -0.08 & 0.9362 & 0.979 & $(0.563-1.701)$ \\
\hline Quarter & 0.06359 & 0.2514 & 16.16 & 0.25 & 0.8035 & 1.066 & $(0.626-1.815)$ \\
\hline Half (Ref) & 0 & . $\quad$. & . & . & & & \\
\hline
\end{tabular}

Relatively small standard error values (and thus margins of error; Table 11) in respect to estimated covariance components for gap-size and parent conclude that estimates are far enough away from zero to deduce reasonable effect on variation among seedling survival rates from each independent variable. Specifically, reasonable effect from gap-size confirms and accounts for correlation between trees within the same gap, whereby verifying the use of the 'mixed effect' model. Parent effect translates to an assured variation among the sample of selected Monterey pine parent trees, which implicates variation in survival rates among Monterey pine parents in the native population.

Table 11. Covariance Parameter Estimates for model prediction survival at 68months.

\begin{tabular}{llc} 
Source of Variation & Estimate & SE \\
\hline Parent & & \\
Gap & 0.1219 & 0.05777 \\
Residual & 0.03944 & 0.01624 \\
& 0.9570 & 0.02853
\end{tabular}




\subsection{Growth}

The height and diameter development of the surviving sample trees at each of the data collection periods are illustrated in Figures 3 and 4. For 12-month post-treatment data collection, 384 sample trees were measured, 315 at 24-months post-treatment, and 271 at 68 -months post-treatment. Sample seedlings in the pile and burn gaps had slightly larger height and diameter averages than seedlings in lop and scatter gaps, which has been the case for all three collection periods. Between gap sizes, the ranks are identical for height and diameter averages. The 0.20 -hectare gaps have the largest growth averages, followed closely by 0.10-hectare gaps, with a dramatic drop to averages for 0.05-hectare gaps. Similar to the trend seen for survival to parent tree, there is an increasingly divergent variability among parent-tree growth averages at 68-months post-treatment.

The descriptive statistics for the growth variables for the 271 surviving sample trees at 68 months post-treatment are outlined in Tables 12 and 13. These numbers reflect the trends observed in Figures 3 and 4 and the inclusion of minimum and maximum values give insight into the wide range of measures within each group. Overall, the seedlings at 68-months post-treatment had grown an average of $397.19 \mathrm{~cm}$ $(\mathrm{SD}=165.3 \mathrm{~cm})$ in height and $66.8 \mathrm{~mm}(\mathrm{SD}=36.8 \mathrm{~mm})$ in diameter. These averages account for a height range of $30.34-792.48 \mathrm{~cm}$ and a diameter range of $6.96-182.88 \mathrm{~mm}$. 

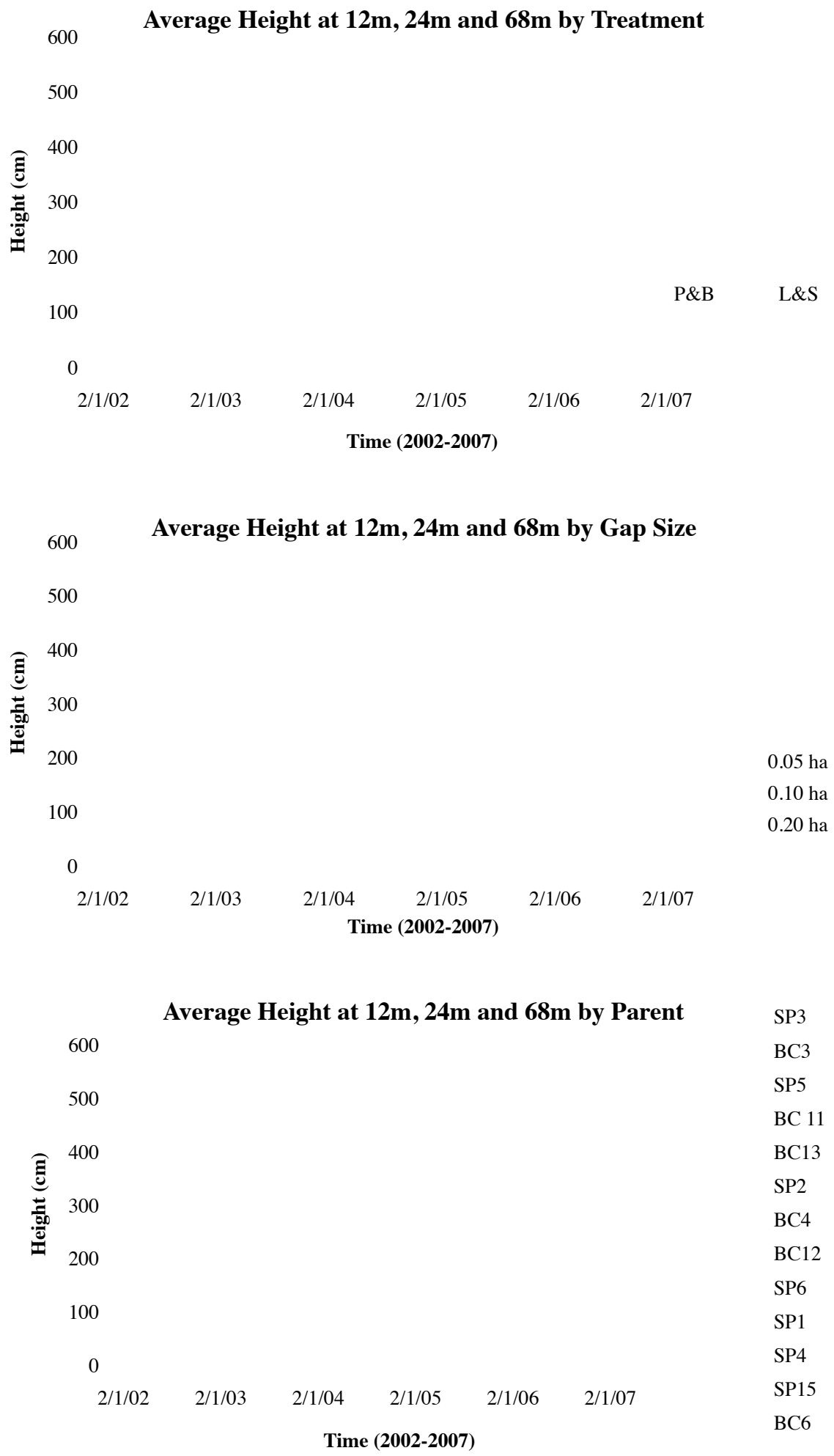

Figure 3. Average height $(\mathrm{cm})$ over time by treatment, gap-size and parent for a sample of 271 seedlings. Source: $12 \mathrm{~m}$ data: Wise, 2004; 24m data: Pinkerton, 2006; 68m data: Loe. 

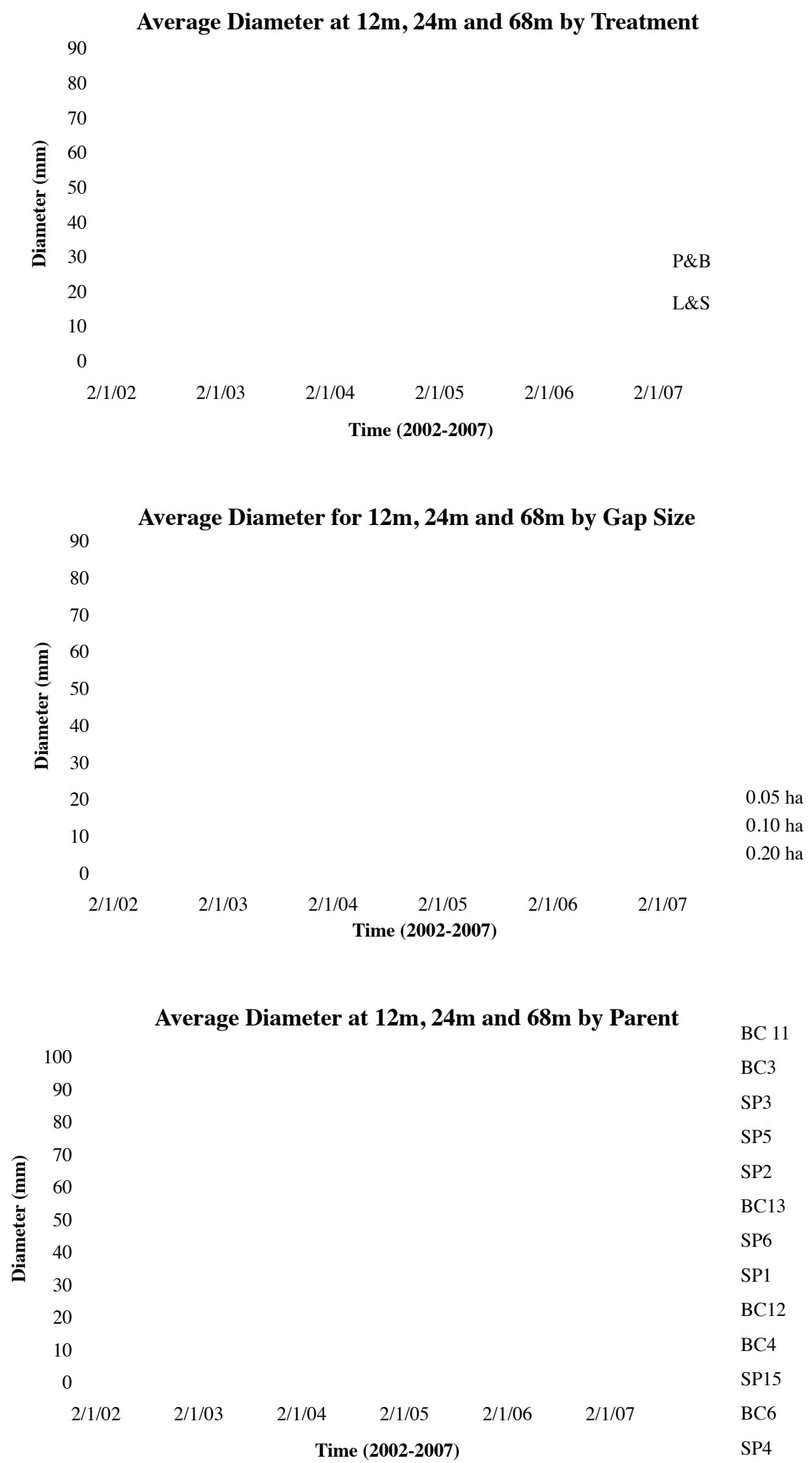

Figure 4. Average diameter $(\mathrm{mm})$ over time by treatment, gap-size and parent for a sample of 271 seedlings. Source: $12 \mathrm{~m}$ data: Wise, 2004; 24m data: Pinkerton, 2006; 68m data: Loe. 
Table 12. Descriptive statistics for height $(\mathrm{cm})$ for sample trees at $68 \mathrm{~m}$ post-treatment.

\begin{tabular}{|c|c|c|c|c|c|}
\hline \multirow[b]{2}{*}{ Group } & \multirow[b]{2}{*}{$\mathrm{n}$} & \multicolumn{4}{|c|}{ Height $(\mathrm{cm})$ at 68 Months } \\
\hline & & Min & Max & Mean & SD \\
\hline All & 271 & 30.48 & 792.48 & 397.19 & 165.34 \\
\hline \multicolumn{6}{|l|}{ Parent } \\
\hline SP1 & 27 & 121.92 & 701.04 & 396.24 & 176.62 \\
\hline SP2 & 25 & 152.40 & 762.00 & 407.82 & 174.89 \\
\hline SP3 & 13 & 213.36 & 762.00 & 477.13 & 160.01 \\
\hline SP4 & 22 & 30.48 & 792.48 & 348.44 & 188.20 \\
\hline SP5 & 16 & 60.96 & 716.28 & 430.53 & 184.36 \\
\hline SP6 & 19 & 76.20 & 624.84 & 401.05 & 164.69 \\
\hline SP15 & 12 & 152.40 & 533.40 & 327.66 & 121.66 \\
\hline BC3 & 23 & 182.88 & 777.24 & 434.01 & 168.20 \\
\hline $\mathrm{BC} 4$ & 20 & 167.64 & 762.00 & 404.47 & 148.73 \\
\hline BC6 & 26 & 76.20 & 731.52 & 325.32 & 166.05 \\
\hline BC11 & 28 & 137.16 & 701.04 & 413.11 & 147.78 \\
\hline BC12 & 21 & 152.40 & 792.48 & 404.22 & 159.96 \\
\hline BC13 & 19 & 45.72 & 670.56 & 413.08 & 148.53 \\
\hline \multicolumn{6}{|l|}{ Gap Size } \\
\hline 0.05 ha & 38 & 60.96 & 624.84 & 290.76 & 149.67 \\
\hline 0.10 ha & 77 & 137.16 & 792.48 & 409.70 & 184.51 \\
\hline 0.20 ha & 156 & 30.48 & 792.48 & 416.93 & 149.45 \\
\hline \multicolumn{6}{|l|}{ Treatment } \\
\hline Pile \& Burn & 150 & 91.44 & 792.48 & 409.33 & 147.00 \\
\hline Lop \& Scatter & 121 & 30.48 & 792.48 & 382.13 & 185.11 \\
\hline
\end{tabular}

Table 13. Descriptive statistics for diameter ( $\mathrm{mm}$ ) for sample trees at $68 \mathrm{~m}$ post-treatment.

\begin{tabular}{|c|c|c|c|c|c|}
\hline \multirow[b]{2}{*}{ Group } & \multirow[b]{2}{*}{$\mathrm{n}$} & \multicolumn{4}{|c|}{ Diameter $(\mathrm{mm})$ at 68 Months } \\
\hline & & Min & Max & Mean & SD \\
\hline All & 271 & 6.96 & 182.88 & 66.80 & 36.82 \\
\hline \multicolumn{6}{|l|}{ Parent } \\
\hline SP1 & 27 & 12.70 & 142.24 & 67.24 & 37.26 \\
\hline SP2 & 25 & 15.24 & 160.20 & 74.86 & 42.91 \\
\hline SP3 & 13 & 20.32 & 147.32 & 76.40 & 34.83 \\
\hline SP4 & 22 & 15.24 & 107.70 & 47.81 & 26.01 \\
\hline SP5 & 16 & 10.16 & 152.40 & 75.28 & 39.19 \\
\hline SP6 & 19 & 7.62 & 142.24 & 67.98 & 38.05 \\
\hline SP15 & 12 & 21.59 & 93.98 & 50.56 & 22.96 \\
\hline BC3 & 23 & 17.78 & 182.88 & 76.53 & 43.16 \\
\hline $\mathrm{BC} 4$ & 20 & 6.96 & 137.16 & 61.18 & 32.90 \\
\hline BC6 & 26 & 10.16 & 134.62 & 49.51 & 33.54 \\
\hline BC11 & 28 & 15.24 & 166.00 & 77.73 & 37.92 \\
\hline $\mathrm{BC} 12$ & 21 & 12.70 & 152.40 & 66.76 & 35.11 \\
\hline $\mathrm{BC} 13$ & 19 & 20.32 & 134.62 & 74.60 & 32.22 \\
\hline \multicolumn{6}{|l|}{ Gap Size } \\
\hline 0.05 ha & 38 & 10.16 & 109.22 & 39.36 & 26.25 \\
\hline 0.10 ha & 77 & 12.70 & 182.88 & 70.73 & 38.76 \\
\hline 0.20 ha & 156 & 6.96 & 166.00 & 71.54 & 35.29 \\
\hline \multicolumn{6}{|l|}{ Treatment } \\
\hline Pile \& Burn & 150 & 6.96 & 182.88 & 67.83 & 34.79 \\
\hline Lop \& Scatter & 121 & 7.62 & 166.00 & 65.51 & 39.29 \\
\hline
\end{tabular}


The estimated parameters for the fixed effects of the model predicting height of seedlings at 68months post-treatment by treatment and gap-size are presented in Table 14. The model also controls for baseline height. Although the model did not detect a significant effect of site-treatment on height, seedlings in pile and burn gaps are predicted to be $38.9 \mathrm{~cm}$ taller than those in lop and scatter gaps. The model detects that gap-size has a partially significant impact on tree height. It is predicted that seedlings in the 0.20 -hectare gaps and 0.10 -hectare gaps will produce heights within a mere $20.49 \mathrm{~cm}$ of each other (pvalue $=0.6764)$. Yet seedlings in 0.20 -hectare gaps are predicted to produce heights $121.684 \mathrm{~cm}$ larger than those in 0.05 -hectare gaps, resulting in a significant p-value of (0.027). This relationship was confirmed with the use of Tukey-Kramer Test (Table 15).

The random parent effect and the variability resulting from differences between gaps are shown in Table 16. The model did not detect significant variability as a result of parent, but does show significant variability in tree height due to gap-to-gap (i.e. among gaps) variance. 
Table 14. Coefficients for fixed effects in model predicting height at 68 months

\begin{tabular}{|c|c|c|c|c|c|}
\hline Effect & Estimate & SE & DF & $\mathrm{t}$ & $\operatorname{Pr}>|t|$ \\
\hline Intercept & 359.162 & 52.574 & 44.4 & 6.83 & $<.0001$ \\
\hline Baseline Height & .33274 & .32637 & 123 & 1.02 & 0.3100 \\
\hline \multicolumn{6}{|l|}{ Treatment: } \\
\hline Pile \& Burn & 38.922 & 41.033 & 18.6 & 0.95 & 0.3550 \\
\hline Lop \& Scatter & 0 & & . & & \\
\hline \multicolumn{6}{|l|}{ Gap Size: } \\
\hline 0.05 ha & -121.684 & 51.082 & 20.5 & -2.38 & 0.0270 \\
\hline 0.10 ha & -20.491 & 48.232 & 16.5 & -0.42 & 0.6764 \\
\hline $0.20 \mathrm{ha}$ & 0 & & . & & \\
\hline
\end{tabular}

Table 15. Tukey-Kramer Adjustment for height of sample trees at 68 months by gap-size

\begin{tabular}{lcccccc} 
Effect & Estimate & SE & DF & $t$ & $\operatorname{Pr}>|t|$ & Adj P \\
\hline 0.05- to 0.10 ha & -101.193 & 5.2460 & 22.7 & -1.93 & 0.0663 & 0.1574 \\
0.05 - to 0.20 ha & -121.684 & 51.082 & 20.5 & -2.38 & 0.0270 & 0.0680 \\
0.10 - to 0.20 ha & -20.491 & 48.232 & 16.5 & -0.42 & 0.6764 & 0.9058 \\
\hline
\end{tabular}

Table 16. Covariance Parameter estimates in model predicting height at 68 months

\begin{tabular}{lcccc} 
Source & Estimate & SE & $\mathrm{Z}$ & $\operatorname{Pr} \mathrm{Z}$ \\
Parent & 21,665 & 48,591 & 0.45 & 0.3278 \\
Gap & $57,741.0$ & $24,243.8$ & 2.38 & 0.0172 \\
Residual & $192,689.6$ & $17,472.6$ & 11.03 & $<.0001$ \\
\hline
\end{tabular}


The estimated parameters for the fixed effects of the model predicting diameter of seedlings at 68 months post-treatment by treatment and gap-size are summarized in Table 17. The model also controls for baseline diameter. Similarly to Table 14 , diameter growth at 68 -months was only significantly affected by gap-size and not by treatment. Although pile and burn gaps are predicted to produce seedlings with a larger average diameter than lop and scatter gaps, the estimated difference is not significant $(\mathrm{p}=0.5365)$. Diameter estimates predicted in 0.20 -hectare gaps surpassed those of the 0.10 - and 0.05 -hectare gaps, by 3.6- and 33.8-mm respectively with the latter being the only significant relationship ( $\mathrm{p}=0.0081)$. The Tukey-Kramer Test results shown in Table 18 supports the gap-size effect between 0.20 -hectare gaps and 0.05-hectare gaps and furthermore detects significant difference between diameter averages yielded by 0.10-hectare gap and those yielded by 0.05 -hectare gaps $(\mathrm{p}=0.0174)$.

The estimated variance components (Table 19) for the model predicting seedling diameter at 68 months shows similar results from the model predicting height. Parent variation has moderately significant impact on variability in diameter difference, whereas gap-to-gap inflicts significant variability $(\mathrm{p}=0.0405)$. 
Table 17. Coefficients for fixed effects in model predicting diameter at 68months.

\begin{tabular}{|c|c|c|c|c|c|}
\hline Effect & Estimate & SE & DF & $\mathrm{t}$ & $\operatorname{Pr}>|t|$ \\
\hline Intercept & 52.0012 & 14.9809 & 85.4 & 3.47 & 0.0008 \\
\hline Baseline Diameter & 6.5993 & 4.7284 & 257 & 1.40 & 0.1640 \\
\hline \multicolumn{6}{|l|}{ Treatment: } \\
\hline Pile \& Burn & 5.6860 & 8.9758 & 14.2 & 0.63 & 0.5365 \\
\hline Lop \& Scatter (Ref) & 0 & .. & & & \\
\hline \multicolumn{6}{|l|}{ Gap Size: } \\
\hline 0.05 ha & -33.8582 & 11.2141 & 16 & -3.02 & 0.0081 \\
\hline $0.10 \mathrm{ha}$ & -3.6224 & 10.5166 & 12.5 & -0.34 & 0.7362 \\
\hline 0.20 ha (Ref) & 0 & & 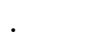 & & \\
\hline
\end{tabular}

Table 18. Tukey-Kramer Adjustment for diameter of sample trees at 68 months by gap-size

\begin{tabular}{lcccccc} 
Effect & Estimate & SE & DF & t & Pr $>|t|$ & Adj P \\
\hline & & & & & & \\
0.05 ha to 0.10 ha & -30.2358 & 11.5266 & 17.7 & -2.62 & 0.0174 & 0.0477 \\
0.05 ha to 0.20 ha & -33.8582 & 11.2141 & 16 & -3.02 & 0.0081 & 0.0222 \\
0.10 ha to 0.20 ha & -3.6224 & 10.5166 & 12.5 & -0.34 & 0.7362 & 0.9370 \\
\hline
\end{tabular}

Table 19. Covariance Parameter estimates in model predicting diameter at 68 months.

\begin{tabular}{lllll} 
Source of Variation & Estimate & \multicolumn{1}{c}{$\mathrm{SE}$} & $\mathrm{z}$ & $\operatorname{Pr} \mathrm{Z}$ \\
\hline Parent & & & & \\
Gap & 65.0055 & 46.0729 & 1.41 & 0.0791 \\
Residual & 270.69 & 132.11 & 2.05 & 0.0405 \\
& 973.68 & 88.5020 & 11.00 & $<.0001$ \\
\hline
\end{tabular}




\subsection{Disease Symptom Occurrence}

The pitch canker infection rates for the 13 parent trees (listed in Table 20) span 18.5- 34.6\%. Of the infected trees, the highest number of symptomatic branch tips and stem cankers on any one tree were 18 and 2 respectively (Tables 20 and 21). Both maximum values were found on individuals from the same parent tree (SP15), the parent that also showed the second highest infection rate for pitch canker. Pile and burn gaps had a nominally higher infection rate (29\%) over that of lop and scatter gaps (28.5\%). 0.10 hectare plots had the highest rate of infection (36.7\%) over 0.20 - and 0.05 -hectare plots $(27.6 \%$ and $16.0 \%$ respectively). Overall, $28.8 \%$ (322) individuals were infected, of which $91.3 \%$ had less than 5 branch flag symptoms. Only $18.6 \%$ (60) exhibited more severe infection with stem or branch cankers. 
Table 20. Descriptive statistics for pitch canker branch-tips symptoms by parent, gap-size, treatment, tree height and resistance rank at 68 -months post-treatment inclusive of p-values for associations determined by contingency tables.

\begin{tabular}{|c|c|c|c|c|c|c|}
\hline & $\mathrm{n}$ & $\begin{array}{c}\text { \# of } \\
\text { Infected } \\
\text { Individuals }\end{array}$ & $\%$ Infected & $\begin{array}{c}\% \text { Not } \\
\text { Infected }\end{array}$ & Min & Max \\
\hline All & 1119 & 322 & $28.8 \%$ & $71.2 \%$ & 0 & 18 \\
\hline \multicolumn{7}{|l|}{ Parent $(* \mathrm{p}$-value $=0.565)$} \\
\hline SP1 & 90 & 26 & $28.9 \%$ & $71.1 \%$ & 0 & 8 \\
\hline SP2 & 93 & 25 & $26.9 \%$ & $73.1 \%$ & 0 & 5 \\
\hline SP3 & 69 & 22 & $31.9 \%$ & $68.1 \%$ & 0 & 7 \\
\hline SP4 & 107 & 37 & $34.6 \%$ & $65.4 \%$ & 0 & 9 \\
\hline SP5 & 81 & 23 & $28.4 \%$ & $71.6 \%$ & 0 & 13 \\
\hline SP6 & 86 & 19 & $22.1 \%$ & $77.9 \%$ & 0 & 9 \\
\hline SP15 & 48 & 16 & $33.3 \%$ & $66.7 \%$ & 0 & 18 \\
\hline $\mathrm{BC} 3$ & 89 & 26 & $29.2 \%$ & $70.8 \%$ & 0 & 8 \\
\hline $\mathrm{BC} 4$ & 90 & 25 & $27.8 \%$ & $72.2 \%$ & 0 & 10 \\
\hline BC6 & 94 & 31 & $33.0 \%$ & $67.0 \%$ & 0 & 9 \\
\hline BC11 & 112 & 35 & $31.3 \%$ & $68.8 \%$ & 0 & 17 \\
\hline BC12 & 92 & 17 & $18.5 \%$ & $81.5 \%$ & 0 & 10 \\
\hline BC13 & 68 & 20 & $29.4 \%$ & $70.6 \%$ & 0 & 12 \\
\hline \multicolumn{7}{|l|}{ Gap Size $(* p-$ value $=0.000)$} \\
\hline 0.05 ha & 150 & 24 & $16.0 \%$ & $84.0 \%$ & 0 & 4 \\
\hline 0.10 ha & 338 & 124 & $36.7 \%$ & $63.3 \%$ & 0 & 18 \\
\hline 0.20 ha & 631 & 174 & $27.6 \%$ & $72.4 \%$ & 0 & 10 \\
\hline \multicolumn{7}{|l|}{ Treatment $(* \mathrm{p}$-value $=0.863)$} \\
\hline Pile \& Burn & 621 & 180 & $29.0 \%$ & $71.0 \%$ & 0 & 17 \\
\hline Lop \& Scatter & 498 & 142 & $28.5 \%$ & $71.5 \%$ & 0 & 18 \\
\hline \multicolumn{7}{|c|}{ Tree Height $(* \mathrm{p}$-value $=0.000)$} \\
\hline$<274 \mathrm{~cm}$ & 299 & 49 & $16.4 \%$ & $83.6 \%$ & 0 & 10 \\
\hline $274.1-396 \mathrm{~cm}$ & 263 & 60 & $22.8 \%$ & $77.2 \%$ & 0 & 18 \\
\hline $396.1-518 \mathrm{~cm}$ & 276 & 98 & $35.5 \%$ & $64.5 \%$ & 0 & 17 \\
\hline$>518.1 \mathrm{~cm}$ & 281 & 115 & $40.9 \%$ & $59.1 \%$ & 0 & 13 \\
\hline \multicolumn{7}{|c|}{ Resistance Rank $(* \mathrm{p}$-value $=0.545)$} \\
\hline Resistant & 391 & 108 & $72.4 \%$ & $27.6 \%$ & 0 & 17 \\
\hline Intermediate & 393 & 110 & $72.0 \%$ & $28.0 \%$ & 0 & 13 \\
\hline Susceptible & 335 & 104 & $68.9 \%$ & $31.0 \%$ & 0 & 18 \\
\hline
\end{tabular}

* p-value for Pearson Chi-Square value for association between symptomatic branch tips to independent factors listed. 
Table 21. Descriptive statistics for pitch canker stem symptoms by parent, gap-size, treatment, tree height and resistance ranking at 68-months post-treatment.

\begin{tabular}{|c|c|c|c|c|c|c|}
\hline & $\mathrm{n}$ & $\begin{array}{c}\text { \# of } \\
\text { Infected } \\
\text { Individuals }\end{array}$ & $\begin{array}{c}\% \\
\text { Infected }\end{array}$ & $\begin{array}{c}\% \text { Not } \\
\text { Infected }\end{array}$ & Min & Max \\
\hline All & 1119 & 60 & $5.4 \%$ & $94.5 \%$ & 0 & 2 \\
\hline \multicolumn{7}{|l|}{ Parent } \\
\hline SP1 & 90 & 4 & $4.4 \%$ & $95.6 \%$ & 0 & 1 \\
\hline SP2 & 93 & 4 & $4.3 \%$ & $95.7 \%$ & 0 & 1 \\
\hline SP3 & 69 & 5 & $7.3 \%$ & $92.8 \%$ & 0 & 1 \\
\hline SP4 & 108 & 7 & $6.5 \%$ & $93.4 \%$ & 0 & 2 \\
\hline SP5 & 81 & 3 & $3.7 \%$ & $96.3 \%$ & 0 & 1 \\
\hline SP6 & 86 & 3 & $3.5 \%$ & $96.5 \%$ & 0 & 1 \\
\hline SP15 & 48 & 4 & $8.3 \%$ & $91.7 \%$ & 0 & 2 \\
\hline BC3 & 89 & 4 & $4.5 \%$ & $95.5 \%$ & 0 & 1 \\
\hline BC4 & 90 & 4 & $4.4 \%$ & $95.6 \%$ & 0 & 1 \\
\hline BC6 & 94 & 7 & $7.4 \%$ & $92.6 \%$ & 0 & 1 \\
\hline BC11 & 112 & 6 & $5.4 \%$ & $94.6 \%$ & 0 & 1 \\
\hline BC12 & 92 & 4 & $4.3 \%$ & $95.7 \%$ & 0 & 1 \\
\hline BC13 & 68 & 5 & $7.4 \%$ & $92.6 \%$ & 0 & 1 \\
\hline \multicolumn{7}{|l|}{ Gap Size } \\
\hline 0.05 ha & 150 & 2 & $1.3 \%$ & $98.7 \%$ & 0 & 1 \\
\hline 0.10 ha & 339 & 17 & $5.0 \%$ & $94.9 \%$ & 0 & 2 \\
\hline 0.20 ha & 631 & 41 & $6.5 \%$ & $93.5 \%$ & 0 & 2 \\
\hline \multicolumn{7}{|l|}{ Treatment } \\
\hline Pile \& Burn & 622 & 38 & $6.1 \%$ & $93.8 \%$ & 0 & 2 \\
\hline Lop \& Scatter & 498 & 22 & $4.4 \%$ & $95.6 \%$ & 0 & 2 \\
\hline \multicolumn{7}{|l|}{ Tree Height } \\
\hline$<274 \mathrm{~cm}$ & 299 & 8 & $2.7 \%$ & $97.3 \%$ & 0 & 1 \\
\hline $274.1-396 \mathrm{~cm}$ & 263 & 15 & $5.7 \%$ & $94.3 \%$ & 0 & 2 \\
\hline $396.1-518 \mathrm{~cm}$ & 276 & 19 & $6.9 \%$ & $93.1 \%$ & 0 & 1 \\
\hline$>518.1 \mathrm{~cm}$ & 281 & 18 & $6.4 \%$ & $93.6 \%$ & 0 & 2 \\
\hline \multicolumn{7}{|l|}{ Resistance Rank } \\
\hline Resistant & 391 & 21 & $5.4 \%$ & $94.6 \%$ & 0 & 1 \\
\hline Intermediate & 393 & 20 & $5.1 \%$ & $94.9 \%$ & 0 & 1 \\
\hline Susceptible & 335 & 19 & $5.7 \%$ & $94.0 \%$ & 0 & 2 \\
\hline
\end{tabular}


The Western Gall Rust infection rates for the13 parent trees (listed in Table 22) span from 2.08$13.24 \%$, with 15 being the highest number of symptomatic stem galls on any one tree (SP3). Pile and burn gaps produced the highest infection rate (7.6\%) over lop and scatter gaps $(6.4 \%)$. Conversely from pitch canker infection results (symptomatic branch tips), 0.05-hectare gaps had the highest infection rate $(9.3 \%)$ over 0.20 - and 0.10 -hectare gaps, (7.4\% and 5.3\% respectively). Overall, only $79(7.1 \%)$ individuals were infected, of which most only contained 1 or 2 galls.

Contingency tables were used to investigate whether there was a relationship between the number of pitch canker (i.e. branch tip) or western gall rust symptoms to site-treatment, gap-size, parent tree, tree height at 68-months post-treatment, resistance screening results, or to each other. The Pearson Chi-Square values (listed in Tables 20 and 22) show a significant relationship between the number of pitch canker symptoms to gap-size $(\mathrm{p}$-value $=0.000)$ and tree height $(\mathrm{p}$-value=0.000). Similarly, the Pearson Chi-Square values show a significant relationship between the number of western gall rust symptoms to tree height ( $\mathrm{p}$ value $=0.001)$. In response to these results of significant association, a secondary contingency table was run to investigate the relationship between gap-size and tree height at 68-months post-treatment. The Pearson Chi-Square value proved significant $(\mathrm{p}=0.000)$. Resistance screening results (Table 2$)$ do not appear to predict the likelihood of pitch canker or western gall rust infection. Lastly, the Pearson Chi-Square value indicates a potentially significant relationship $(\mathrm{p}$-value $=0.061)$ between the numbers of pitch canker and gall rust symptoms. 
Table 22. Descriptive statistics for western gall rust symptoms by parent, gap-size, treatment tree height, and resistance rank at 68 -months post-treatment inclusive of p-values for associations determined by contingency tables.

\begin{tabular}{|c|c|c|c|c|c|c|}
\hline & $\mathrm{n}$ & $\begin{array}{l}\text { \# of Infected } \\
\text { Individuals }\end{array}$ & $\begin{array}{c}\% \\
\text { Infected }\end{array}$ & $\begin{array}{l}\% \text { Not } \\
\text { Infected }\end{array}$ & Min & $\operatorname{Max}$ \\
\hline All & 1119 & 79 & $7.1 \%$ & $92.9 \%$ & 0 & 15 \\
\hline \multicolumn{7}{|l|}{ Parent $(* \mathrm{p}$-value $=0.153)$} \\
\hline SP1 & 90 & 8 & $8.9 \%$ & $91.1 \%$ & 0 & 1 \\
\hline SP2 & 93 & 5 & $5.4 \%$ & $94.6 \%$ & 0 & 1 \\
\hline SP3 & 69 & 7 & $10.1 \%$ & $89.9 \%$ & 0 & 15 \\
\hline SP4 & 107 & 6 & $5.6 \%$ & $94.4 \%$ & 0 & 2 \\
\hline SP5 & 81 & 3 & $3.7 \%$ & $94.4 \%$ & 0 & 1 \\
\hline SP6 & 86 & 6 & $7.0 \%$ & $93.0 \%$ & 0 & 2 \\
\hline SP15 & 48 & 1 & $2.1 \%$ & $97.9 \%$ & 0 & 1 \\
\hline $\mathrm{BC} 3$ & 89 & 5 & $5.6 \%$ & $94.4 \%$ & 0 & 1 \\
\hline $\mathrm{BC} 4$ & 90 & 7 & $7.8 \%$ & $92.2 \%$ & 0 & 1 \\
\hline BC6 & 94 & 4 & $4.3 \%$ & $95.7 \%$ & 0 & 1 \\
\hline $\mathrm{BC} 11$ & 112 & 14 & $12.5 \%$ & $87.5 \%$ & 0 & 3 \\
\hline $\mathrm{BC} 12$ & 92 & 4 & $4.3 \%$ & $95.7 \%$ & 0 & 2 \\
\hline $\mathrm{BC} 13$ & 68 & 9 & $13.2 \%$ & $86.8 \%$ & 0 & 2 \\
\hline \multicolumn{7}{|l|}{ Gap Size $(* p$-value $=0.237)$} \\
\hline 0.05 ha & 150 & 14 & $9.3 \%$ & $90.7 \%$ & 0 & 2 \\
\hline 0.10 ha & 338 & 18 & $5.3 \%$ & $94.7 \%$ & 0 & 1 \\
\hline 0.20 ha & 631 & 47 & $7.4 \%$ & $92.6 \%$ & 0 & 15 \\
\hline \multicolumn{7}{|c|}{ Treatment $(* \mathrm{p}$-value $=0.458)$} \\
\hline Pile \& Burn & 621 & 47 & $7.6 \%$ & $92.4 \%$ & 0 & 2 \\
\hline Lop \& Scatter & 498 & 32 & $6.4 \%$ & $93.6 \%$ & 0 & 15 \\
\hline \multicolumn{7}{|c|}{ Tree Height $(* \mathrm{p}$-value $=0.001)$} \\
\hline$<274 \mathrm{~cm}$ & 299 & 8 & $3.0 \%$ & $97.0 \%$ & 0 & 1 \\
\hline $274.1-396 \mathrm{~cm}$ & 263 & 15 & $11.8 \%$ & $88.2 \%$ & 0 & 2 \\
\hline $396.1-518 \mathrm{~cm}$ & 276 & 19 & $8.0 \%$ & $92.0 \%$ & 0 & 1 \\
\hline$>518.1 \mathrm{~cm}$ & 281 & 18 & $6.0 \%$ & $94.0 \%$ & 0 & 2 \\
\hline \multicolumn{7}{|c|}{ Resistance Rank $(* \mathrm{p}$-value $=0.846)$} \\
\hline Resistant & 391 & 27 & $6.9 \%$ & $93.1 \%$ & 0 & 1 \\
\hline Intermediate & 393 & 30 & $7.6 \%$ & $92.4 \%$ & 0 & 1 \\
\hline Susceptible & 335 & 22 & $6.6 \%$ & $93.4 \%$ & 0 & 2 \\
\hline
\end{tabular}

$*$ p-value for Pearson Chi-Square value for association between symptomatic stem galls to independent factors listed. 


\subsection{Spatial Analysis}

Azimuth analysis indicates that only a very slight differential exists between survival and growth (i.e. height) performance among artificially regenerated seedlings in quartered plots at 24 months posttreatment. Among quadrants in all six analysis-periods there is an overall range in survival rates of 49.8$61.9 \%$ (both extremes produced by quadrants from the same time period: September 23, 2003). A trend seen through the year shows that seedlings in the $2^{\text {nd }}$ and $3^{\text {rd }}$ Quadrants had the highest chance of survival, followed closely by Quadrant 4, leaving seedlings in Quadrant 1 (receiving most direct sunlight) with the lowest odds of survival. A contingency table used to assess the association between survival and quadrant for the September $23^{\text {rd }}$ time period provided a significant Pearson Chi-Square value $(\mathrm{p}=0.000)$. Similar to overall survival observations, yet with inversed results, there is an apparent trend within the fairly narrow range of height averages $(32.5-44.5 \mathrm{~cm})$. Generally Quadrant 1 or 4 (receiving the most direct sunlight) had the highest growth average followed by 2, leaving seedlings in Quadrant 3 with the lowest growth performance.

\section{Discussion}

\subsection{Pre-treatment Conditions}

The Scott's Creek unit is diverse in structure and composition, containing a mix of both conifer and broadleaf species with a wide range of diameter and density measures. Similar results were reported in Piirto and Valkonen's 2005 article. Structural variability caused by events such as moderate intensity fires, disease infestations and timber harvests have created sections of regeneration, and thus recruitment of intermediate and co-dominant pines within the stand. Overall, larger and older Monterey pines do not dominate the stand's overstory, but instead there is a greater number of trees from the smaller diameter classes. Disease appraisal indicates that infection rates have risen since 2005 survey from $35.3 \%$ to $65.4 \%$, climbing towards the 90\% recorded in 1999 (Henry, 2005; Piirto \& Valkonen, 1999).

\subsection{Understory Vegetation}

Through the 68 months since treatment, the evolution in understory cover can be characterized by sustained growth, consistent presence of few specific species, and changes in cover proportion. The most 
notable changes have been discernable swells in cover percentage of weedy and grass species, a dramatic decrease of unvegetated areas, and the continued increase of species diversity and poison oak.

The abundance of weedy species seen at 12-months post-treatment and the increased proportion of grass seen at 24-months post-treatment were both reduced by 68 -months post-treatment. Considering these two categories encountered similar reversion from understory abundance back towards original trace occurrence, it appears they could be sequential sere in the allogenic succession of the study-site.

Adversely, unvegetated space within the study area has decreased substantially since sitetreatment. Throughout the study-site, the amount of litter and bare ground has decreased from $45 \%$ to $3 \%$ in the 68 months since treatment. This decrease in abundance is counter-balanced by the increase of poison oak and species diversity.

Overall, poison oak in the study-site has gradually increased over the 68-months post-treatment from 21 to $28 \%$. Although abundant in the pre-treatment study site, the cover of poison oak at 68 -months shows an unprecedented dominance of the understory. This may be due to a variety of factors such as: 1) a positive reaction to the disturbance caused by site-treatment, 2) the species' ability to survive in a variety of moisture and sun intensities, 3) and the species' suppression capability. In full sun these plants can develop into a dense shrub 1-6' high with a wide-spread root system, suppressing nearby species (DiTomaso and Lanini, 2009).

Species diversity, encompassing the 'other species' category and the introduction of new species (species not recorded in previous survey-summaries) has increased across the study site, including control plots. Appearances of species such as blue blossom in pile and burn gaps, mountain iris in the 0.05 -hectare lop and scatter gaps, and poison hemlock in 0.20 - and 0.10 -hectare lop and scatter gaps could be the result of several factors: 1) increased human, animal and treatment activity within the study site, 2) random or episodic seed (residual or from adjacent stands) germination and establishment as light, moisture, and competition levels change within the plot, and 3) close proximity to grazed rangeland.

The species that have increased or maintained presence in the understory vegetation appear to be the ones that can survive on very little unvegetated space and withstand the domination of the Monterey pine seedlings, poison oak, and other well established individuals. 


\subsection{Natural Regeneration}

In hopes of sustaining a population, reproduction for any species is paramount. With pretreatment regeneration proportion favoring hardwoods (79\%) rather than softwoods (21\%), the outlook seemed dismal for Monterey pine within the Scott's Creek Management unit. Without fire or small-scale disturbances, studies indicate that this stand could evolve from a Monterey pine to a Coast Live/Shreve oak forest type (Piirto and Valkonen, 2005).

However, by 24 months post-treatment, the chances for natural regeneration pines appeared to be increasing. Survey of the naturally occurring seedlings at the understory level showed softwood species composition within the study-area had risen $21 \%$, totaling $42 \%$. Pre-treatment, Monterey pine seedlings comprised only $8 \%$ of species composition, yet by 24 -months post treatment, that percentage had more than quadrupled (38\%). These results are not conclusive yet encourage further research and breed hope for restoration of this native stand.

Naturally occurring Monterey pine seedlings within the treated gaps at 68 months post-treatment show that although the difference may not be significant, pile and burn gaps produce more than lop and scatter plots or control plots (47.2-, 43.4- and 9.4\%, respectively). This result is expected, where Monterey pines are known to prefer the conditions left by a fire occurrence (e.g. bare soil, cleared competition). The differences in regeneration success are a bit harder to interpret for gap-size. Although it is clear that 0.05hectare plots in the study produced a significantly fewer amount of natural regeneration trees, it must be considered that 0.05 -hectare plots are one-fourth the size of 0.20 -hectare plots. Thus, the former actually produced more trees/hectare than the latter. Overall, by 68 months post-treatment the 0.10 -plots produced the most naturally occurring Monterey pine seedlings per hectare.

The 0.10-hectare gap-size may be just right in regard to elemental exposure, whereas the proportionately few naturally occurring seedlings in 0.20 -hectare plots could be accredited to excessive exposure to sunlight allowed by a larger canopy gap or quick development of shade-intolerant understory vegetation that prevented seedling germination and establishment. Adversely the low number of naturally occurring seedlings in 0.05 -hectare gaps can be attributed to a lack of necessary sunlight resulting from the small gap-opening or the edge-effect is smaller for the inferior gap-sizes and thus the plot is less heavily exposed to seeds from mature buffer-trees. The latter may also account for the lower number of seedlings 
in the inner and middle rings of the circular plots. It is not surprising that a higher density of seedlings will be closer to the edge of the plot where a heavier seed shower may be experienced.

\subsection{Survival of Artificially Regenerated Seedlings}

With the goal of restoring a strong population of Monterey pine in native stands, high odds of survival of artificially regenerated seedlings is fundamental. Results from 68-month post-treatment survey show that indeed, there is an advantage to preparing planting sites with a pile and burn treatment. As discussed above in regards to natural regeneration, higher rates of survival are expected since we are dealing with a species that is specifically adapted for post-fire occurrence establishment. The bare soil, elimination of competition, increased availability to nutrients (e.g. calcium and phosphorous) and sun exposure in sites has given seedlings in the study a $51.7 \%$ better chance of survival over seedlings in the lop and scatter plot (p-value=0.066) (Wise, 2004).

The lower survival odds of seedlings in lop and scatter plots can be accredited to several factors, most of which are a result of the remaining slash layer: 1) remnant fungal inoculums (e.g. pitch canker) in slash, 2) decreased nutrients lost to decomposition of slash (e.g. nitrogen), 3) increased moisture and temperature of soil due to blanket of slash, 4) decreased sun exposure to seedlings, and lastly, 5) the lesser degree of site-disturbance in comparison to pile and burn plots (Wise, 2004; McDonald \& Laacke, 1990). Although a layer of slash may slow the growth of weedy or shade intolerant competition-species, the thicker layer of biomass effectively acts against the seedlings' growth preferences (e.g. full sun, bare soil, and minimal competition) to discourage establishment and ultimately survival (Gotou \& Nishimura, 2003; McDonald \& Laacke, 1990).

Survival results yielded in the three gap-sizes do not conclusively suggest that any one gap-size is significantly beneficial for survival odds of artificially regenerated seedlings. The results seen at 68-month post-treatment do not correspond to results seen at 12- and 24-months post-treatment. In fact the gap-size with the lowest average survival rate (0.10-hectare plots) in previous surveys now shows superior rates over the other two gap-sizes. At 12-months post-treatment, low survival in 0.10-hectare gaps was partially attributed to cattle damage. By 24-month survey, animal effects (e.g. cattle, deer and feral pig) were 
distributed between all plots and thus no longer inflicted uncontrolled influence upon 0.10-hectare gaps (Pinkerton, 2006). This may consequently explain the reversal in survival rates among gap sizes.

Survival analysis of seedlings from the 13 parent-trees shows a fairly wide range of rates. The offspring from parent SP15 (screened 'highly susceptible' to pitch canker) have consistently been the least likely to survive since project inception. Similarly, seedlings from parent trees BC11 and SP2 (screened 'resistant' to pitch canker) represent two of the top three survival rates. These results could indicate either a relationship between screening-results and seedling survival or marks overall phenotypic hardiness of an individual. However, this trend is not consistent among comparisons for all parent tree results. Further studies may conclusively decipher whether or not a relationship exists between survival rates and pitch canker resistance. Survival rates also show no observable pattern of between parents sourced from Swanton Pacific Ranch and Big Creek Lumber's portion of the Año Nuevo stand.

\subsection{Growth of Artificially Regenerated Seedlings}

Results from tested predictor variables show observable, and sometimes dramatic, impacts upon height and diameter of sample-seedlings $(n=271)$ at 68 -months post-treatment. Note the growth data for all surviving original seedlings $(\mathrm{n}=1119)$ show nearly identical performance averages overall and by treatment, gap-size, and parent, substantiating the validity of sample-set's results. Pile and burn gaps generated the largest growth averages of the two site-treatments, yet not with statistical significance.

Most notable was the relationship between growth averages in gap-sizes, specifically between 0.20- and 0.05-hectare gaps. 0.20-hectare gaps yielded seedlings with a significantly larger height and diameter averages over the mean measures yielded 0.05-hectare gaps ( $\mathrm{p}$-values $=0.027$ and 0.0081 respectively). The differences between growth averages yielded in 0.20- and 0.10-hectare gaps are nominal, indicating very little variability between these two gap-sizes.

Seedlings in 0.20-hectare gaps, once established, may have superior growth averages due to more abundant sunlight, creating an optimal balance of temperature, moisture and exposure conditions.

Additionally, there may be an element of decreased competition when considering the nominal differences in growth between seedlings in 0.20 - and 0.10- acre gaps. Superior survival results in 0.10-hectare gaps translate to a higher density of trees competing for water, nutrients and sunlight. Thus, trees in 0.20 -hectare 
gaps may have a better chance to flourish as a result of a mortality-induced decrease in seedling density (McDonald \& Laacke, 1999).

The 13 parent trees produced a dramatic range of growth averages (both height and diameter). Consistently through the study the same parents hover at the top of the range and others at the bottom. Albeit, not statistically significant, this information warrants attention and further research as choices are made for plantation plantings when yield is critical.

\subsection{Disease Symptom Occurrence}

With the first detection of disease symptoms during the 68-months post-treatment survey, an observation can be made regarding infection rates. The lack of an observed pattern between in-field pitch canker infection results (i.e. symptomatic branch tips) to resistance ratings is reinforced by the insignificant Pearson Chi-Square value ( $\mathrm{p}$-value $=0.545$ ). The dissimilarity between infection and survival rankings by parent may be accredited to fatal infections that went unaccounted for (cause of death was not investigated for 'dead' or 'missing' seedlings) skewing detected infection rates or that pollen source (uncontrolled in study) may be influential on expressed resistance. Further research is needed to determine whether screening methods outlined by Gordon et. al (1998) are appropriate for prediction of infection resistance when only mother tree is controlled.

Descriptive analysis indicated a significant relationship between pitch canker incidence (as represented by detection of symptomatic branch tips) to gap-size and tree height. The explanation for these two relationships may be one and the same. Considering the larger growth averages in 0.20 - and 0.10 - acre gaps, trees in these gaps may experience higher rates of infection due to the increased amount of surface area, translating to an increased opportunity for wounding and infection occurrence. The association between the odds of pitch canker infection and tree size was also detected by Piirto and Valkonen's models, where trees with a diameter smaller than $25.4 \mathrm{~mm}$ were less often infected than those over 25.4mm (2005). It is also possible the environmental conditions in these gaps (e.g. increased exposure to sun, rain, wind) could exacerbate spore dispersion and/or wounding agents. Surprisingly, no relationship is detected between site-treatment and pitch canker incidence, possibly suggesting that unsterilized biomass in lop and scatter plots does not put seedlings at greater risk of infection over those in pile and burn plots. However, it 
is more likely that a relationship exists yet was not detected due to low survival rates of trees in lop and scatter plots, where seedlings were fatally infected and therefore not accounted for by 68 month posttreatment disease survey.

Also notable is the difference between overall rates for less severe infection (e.g. symptomatic branch tips; $28.8 \%$ ) and for more advanced infection (e.g. stem and branch canker; 5.4\%). This dramatic contrast aligns with previous observation that pitch canker initially affects many trees in stand prior to advanced development in individual trees (Storer et. al, 2002).

Western gall rust has a less profound impact on the seedlings in the study site, however, it is important to mention the moderately significant relationship determined in the descriptive analysis between pitch canker and gall rust symptoms. These results may simply confirm that trees infected by one disease are predisposed for attack from other pests or pathogens. But the question to ask: is there a lesson to be learned regarding detection or management of pitch canker from this relationship?

\subsection{Spatial Relationship}

Observable trends exist in azimuth analyses for survival and growth performance, yet for the most part the ranges are fairly narrow. Preliminary analysis of the time period exhibiting the largest range in survival rates among quadrants (September 23, 2003) shows the contrary where the association is

significant. It appears that direct sunlight (e.g. as received by Quadrant 1) is conducive to increased growth averages yet also increases mortality rates. Further research may provide useful insight into the association between seedling performance (i.e. survival and growth), contributing to the knowledge base for development of a management plant for native Monterey pine stands.

In hopes of developing management guidelines for Monterey pine, existing real-world restraints were considered in the experimental design. Conducting the experiment in-lab would have had some benefit, however results derived under actual conditions would be most applicable to the native stands. Most notable are the limitations presented by California Forest Practice Rules, environmental politics, project budget, ecological integrity, and operational environment (Wise, 2004). 


\section{Conclusions}

Future ecological and financial value of Monterey pine is reliant upon healthy native stands. Problems for the species' native populations caused by urban fragmentation, introduction of invasive vegetation, and genetic contamination are exacerbated by decreased regeneration (i.e. suppression resulting from fire policy and association with shade-tolerant broadleaf species) and the introduction of pitch canker. Taking no action to combat these threats is anticipated to result in more advanced deterioration, whereas gap-openings in the canopy and use of resistant seed stock (e.g. pitch canker) can help counterbalance the aforementioned regeneration constraints and contribute to restored forest health (Piirto \& Valkonen, 2005; Storer et. al., 2001).

The results of this study confirm the following conclusions for survival, growth, and disease infection of Monterey pine seedlings within uneven-aged silvicultural management strategy:

\section{Seedling Survival:}

1. Gaps prepared with pile and burn site treatment produce higher survival rates than gaps treated with lop and scatter site treatment (68- months post-treatment). This site-preparation technique abides by regulations mandated for the study site.

2. Gap-size (i.e. 0.20-, 0.10-, and 0.05-hectare) does not have a significant effect on seedling survival (68months post-treatment).

3. A range in parent survival rates for the 13 tested parents indicates a genotypic impact on survival success. Thus, seed source is an important consideration for reforestation.

\section{Seedling Growth:}

1. Seedling growth (i.e. height or diameter) is not significantly affected by site-treatment (68-months posttreatment).

2. Gap-size has a partially significant effect on seedling height (68-months post-treatment). Seedlings in 0.20-hectare gaps had average heights significantly larger than those in 0.05-hectare gaps.

3. Gap-size has a partially significant effect on seedling diameter (68-months post-treatment). Seedlings in 0.20 - and 0.10 -hectare gaps had average diameters significantly larger than those in 0.05 -hectare gaps. 
4. Seedling growth it not significantly affected by parent tree (68-months post-treatment).

Disease:

1. Pitch canker infection rates are not significantly associated with site treatment (68-month posttreatment).

2. Pitch canker infection rates are significantly associated with gap-size though this may be confounded by tree height (68-month post-treatment).

3. Pitch canker infection rates are not significantly associated with parent (68-month post-treatment).

Artificial gap-phase regeneration as explored by this study in synthesis with other techniques may provide a sound foundation for development of an effective management plan critical for restoring health in native Monterey pine stands. Namely, a combination of genetic conservation (in situ and ex situ) and prohibition of exotically propagated Monterey pines will help to maintain invaluable genetic variability and integrity of each distinct population, protecting evolutionary adaptability (Rogers et al., 2004; Deghi et al., 1995). Development of a catalog of resistant seed stock will be a critical component to a successful plan as it will allow for successful reforestation of native stands and will eliminate disease losses in international plantations. As our world evolves environmentally, ecologically, politically, legally, and socially, it is important that an appropriate, attentive variety of measures be taken to maintain the prized Monterey pine in the context of the $21^{\text {st }}$ Century and beyond. 


\section{References}

Adams, D. 1997. Western Pines and western gall rust. Tree Notes \#22: California Department of Forestry and Fire Protection.

Aegerter, B.J., T.R. Gordon. 2006. Rates of pitch canker induced seedling mortality among Pinus radiata families varying in levels of genetic resistance to Gibberella circinata (anamorph Fusarium circinatum). Forest Ecology and Management 235: 14-17.

Auten, S. 2010. Personal communication. Resource Manager, Swanton Pacific Ranch, Davenport, CA.

California Polytechnic State University San Luis Obispo. 2007. Nonindustrial Timber Management Plan: Swanton Pacific Ranch.

(URL: ftp://thp.fire.ca.gov/THPLibrary/North_Coast_Region/NTMPs2007/1-07NTMP-020SCR/) (Ver. 29 May 2010)

Cope, A. 1993. Pinus radiata. In: Fire Effects Information System, [Online]. U.S. Department of Agriculture, Forest Service, Rocky Mountain Research Station, Fire Sciences Laboratory (Producer).

(URL: http://www.fs.fed.us/database/feis/ ) (Ver 8. Oct. 2008)

Dallara, P.D., A.J. Storer, T.R. Gordon, and D.L. Wood. 1995. Current

Status of Pitch Canker Disease in California. Berkeley, California: Department of Environmental Science, Policy and Management, Division of Environmental Biology,

(URL: http://frap.cdf.ca.gov/pitch\%5Fcanker/prevention_management/treenotes.html)

(Ver. 23. Jan.2008)

Deghi, G.S., T. Huffman, and J.W. Culver. 1995. California's native Monterey pine population: potential for sustainability. Fremontia 23: 14-23

DiTomaso, J. M., W. T. Lanini. 2009. IPM Education and Publications, UC Statewide IPM Project, University of California, Davis

(URL: http://www.ipm.ucdavis.edu) (Ver. 26. Apr. 2010)

Dwinell, L.D. 1999. "Contamination of Pinus radiata seeds in California by Fusarium circinatum." Athens, Georgia: USDA Forest Service, Southern Research Station.

European and Mediterranean Plant Protection Organization and CAB International. Data sheets on quarantine pests: Endocronartium harknessii

(URL: www.eppo.org/QUARANTINE/fungi/.../ENDCHA_ds.pdf)

(Ver. 09. May. 2010)

Forde, M.B. 1964. Pinus radiata in California. Forest Research Institute, Rotorua.

Ganley, R.J., M.S. Watt, L. Manning, and E. Iturritxa. 2009. A global climatic risk assessment of pitch canker disease. Can. Jour. of For. Res. 39(11): 2246-2256.

Gordon, T.R. 2006. Pitch canker disease of pines. Phytopathology. 96 (6): 657-659.

Gordon, T.R., A.J. Storer, and D.L. Wood. 2001. The pitch canker epidemic in California. Plant Disease 85(11): 1128-1139

Gordon, T.R., K.R. Winkler, S.L. Clark, D. Okamota, A.J. Storer, and P. Bonello. 1998.

Resistance to pitch canker disease, caused by Fusarium subglutinans f.sp. pini, in Monterey pine (Pinus radiata). Plant Pathology 47: 706-711 
Gotou, J., T. Nishimura. 2003. Effects of slash chips placed around trees planted after whole-tree logging: movement and nutrient supply. J. For. Res. 8: 67-76

Harrington, T.C., M.J. Wingfield. 1998. "Diseases and the ecology of indigenious and exotic pines". P. 381-404. In: Richardson, D.M. (ed.) Ecology and biogeography of Pinus. Cambridge University Press, Cambridge.

Henry, B.P. 2005. Monterey Pine (Pinus radiata) in California: Variation Among Native Forests and Health as a Predictor of Tree Removal in an Urban Forest. M.S. thesis Michigan Technological University, Houghton, MI.

Libby, W.J., M.H. Bannister, and Y.B. Linhart. 1968. "The pines of Cedros and Guadalupe Islands." Journal of Forestry 66 (11): 846-853

Lund, U. 2007. Technical Report: Statistical Analysis of Monterey pine seedling growth and survival at 24 months, Swanton Pacific Ranch, 2001-2003. California Polytechnic State University, San Luis Obispo, CA.

Mark, W. 2009. Personal communication. Professor, Cal Poly State University, San Luis Obispo, CA.

McCain, A.H., C.S. Koehler, and S.A. Tjosvold. 1987. Pitch canker threatens California pines. Calif. Agric. 41: 22-23

McCulloch, C.E., S.R. Searle. 2001. Generalized, Linear, and Mixed Models. John Wiley \& Sons, Inc.: New York, New York.

McDonald, P.M., R.J. Laacke. 1990. “Pinus radiata D. Don Monterey pine”. In: Burns, R.M., Honkala, B.H., technical coordinators. Silvics of North America. Volume 1. Conifers. Agric. Handbook. 654. Washington, D.C.: U.S. Department of Agriculture, Forest Service: 433-441.

Moulds, F.R. 1950. Ecology and Silviculture of Pinus radiata (Don) in California and in southern Australia. Doctorial Dissertation, Yale University.

Offord, H.R. 1964. Diseases of Monterey pine in native stands of California and in plantations of western North America. USDA Forest Service, Research Paper PSW-14. P. 1-9. Pacific Southwest Forest and Range Experiment Station, Berkeley, CA.

Oregon State University Extension: An online guide to plant disease control. Western gall rust fact sheet: (URL: http://plant-disease.ippc.orst.edu/disease.cfm?RecordID=858)

(Ver. 09.May. 2010)

Piirto, D.D., S.Valkonen. 2005. Structure and development of pitch canker infected Monterey pine stands at Año Nuevo, California. Forest Ecology and Management 213: 160-174.

Pinkerton, J. 2006. Silvicultural management strategies for pitch canker infected Año Nuevo stands of Monterey pine: second year gap regeneration results, Master Thesis, California Polytechnic State University, San Luis Obispo, CA.

Rogers, D.L. 2004. In situ genetic conservation of a naturally restricted and commercially widespread species, Pinus radiata. Forest Ecology and Management 197: 311-322 
Rogers, D.L., J.J. Vargas Hernández, A.C. Matheson, and J.J. Guerra Santos. 2002. The Mexican island populations of Pinus radiata: an international expedition and ongoing collaboration for genetic conservation. Food and Agricultural Organization of the United Nations. (URL:http://www.fao.org/docrep/005/y4341e/y4341e07.htm\#P947_91075) (Ver. 7 May 2010)

Roy, D.F. 1966. Silvical Characteristics of Monterey Pine. USDA Forest Service Research Paper PSW31. P. 1- 16. Pacific Southwest Forest and Range Experiment Station, Berkeley, CA.

Smith, D.M., B.C. Larson, M.J. Kelty, and P.S. Ashton. 1997. The Practice of Silviculture: applied forest ecology: ninth edition. John Wiley \& Sons Inc: New York, New York.

Storer, A.J., D.L. Wood, and T.R. Gordon. 2002. The Epidemiology of Pitch Canker of Monterey Pine in California. Forest Science 48: 694-700.

Storer, A.J., D.L. Wood, T.R. Gordon, and W.J. Libby. 2001. Restoring native Monterey pine forests in the presence of an exotic pathogen. Jour. of Forestry 99(5): 14-18

Storer, A.J., T.R. Gordon, P.L. Dallara, D.L. Wood. 1994. Pitch canker kills pines, spread to new species and regions. California Agriculture. 48(6): 9-13.

Storer, Andrew J., Thomas R. Gordon, David L. Wood, Paul L. Dallara. Undated.

"Pitch Canker in California." Berkeley, California: Department of Environmental Science, Policy and Management, Division of Environmental Biology.

(URL: http://frap.cdf.ca.gov/pitch_canker/research/pitchcan.html) (Ver. 23 Jan. 2008)

Stuart, J.D., J.O. Sawyer. 2001. Trees and Shrubs of California. P. 89-90. University of California Press, Berkeley.

U.S. Department of Commerce, National Oceanic \& Atmospheric Administration, National Environmental Satellite, Data, and Information Service. 2004.

Climatography of the United States National Climatic Data Center. Asheville, North Carolina.

(URL: http://ggweather.com/climate/santa_cruz.htm) (Ver. 09 May 2010)

University of California Berkeley. 2010. Jepson Flora Project: Jepson Exchange. Index to Treatments and Keys from The Jepson Manual.

(URL: http://ucjeps.berkeley.edu/interchange/I_treat_indexes.html) (Ver. 25. May. 2010)

White, K. L. 1999. Revisiting native Pinus radiata forests after twenty-nine years. Madroño 46(2): 80-87

Wikler, K., A.J. Storer, W. Newman, T.R. Gordon, and D.L. Wood. 2003. "The dynamics of an introduced pathogen in a native Monterey pine (Pinus radiata) forest." Forest Ecology and Management 179: 209-221.

Wise, E. 2004. Silvicultural management strategies for pitch canker infected Año Nuevo stands of Monterey pine: first year gap regeneration results, Master Thesis, California Polytechnic State University, San Luis Obispo, CA. 


\section{SUPPLEMENTAL RESULTS AND ANALYSES}

Below are additional data and analyses that provide a more intensive look into the project's results. The purpose of the section is to augment the results section of the preceding manuscript with information not pertinent or necessary for publication.

\section{Understory Vegetation}

In addition to the previous briefing of understory vegetation for overall study site and by site treatment, below is a full account of survey results by treatment and gap-size (summary results presented in Figures 5,6, and 7). Understory vegetation in control plots at 68 months was dominated by poison oak and 'other species', staying fairly consistent with surveys from 12- and 24-months post-treatment. Blackberry has maintained presence but decreased by about half in all plot sizes. The appearance of grasses in the 0.20 - and 0.10 -hectare plots was another of the most noted differences. Adversely, grass cover in 0.05 hectare plots decreased by month 68 from a peak at month 24 . Thistle occurrence also declined from previous surveys in 0.10 - and 0.05 -hectare gaps.

In pile and burn plots, poison oak and 'other species' dominated. Both categories showed increased cover since 12- and 24-month surveys. Blackberry and grasses accounted for substantial amounts of cover, coming back from a lull seen at 24 months yet not reaching the peak percentages seen at 12 months. Poison hemlock remains present in all three gap-sizes with around 5\% cover. Other noted changes were a rise in cover of blue blossom in the 0.20 - and 0.05 - acre gaps and a dramatic rise in stinging nettle in the 0.05-hectare gaps. Decreases in unvegetated areas, burnweed, braken, hedge nettle, and thistle have made room for the aforementioned cover increases.

Much like the other plots in the study, lop and scatter gaps were predominately vegetated by poison oak, 'other species', blackberry, and grasses. Understory in 0.10-hectare gaps are most strongly dominated by poison oak whereas both 0.20 - and 0.05 -hectare gaps have a more even distribution of abovenamed species/categories. Mountain iris and poison hemlock were first recorded in the lop and scatter gaps at 68 months whereas species observed in previous surveys, such as burnweed, hedge nettle, hedge parsley, skunkweed, and thistle, have decreased to trace occurrence (0-5\%). 
Pile \& Burn 0.20 Hectare
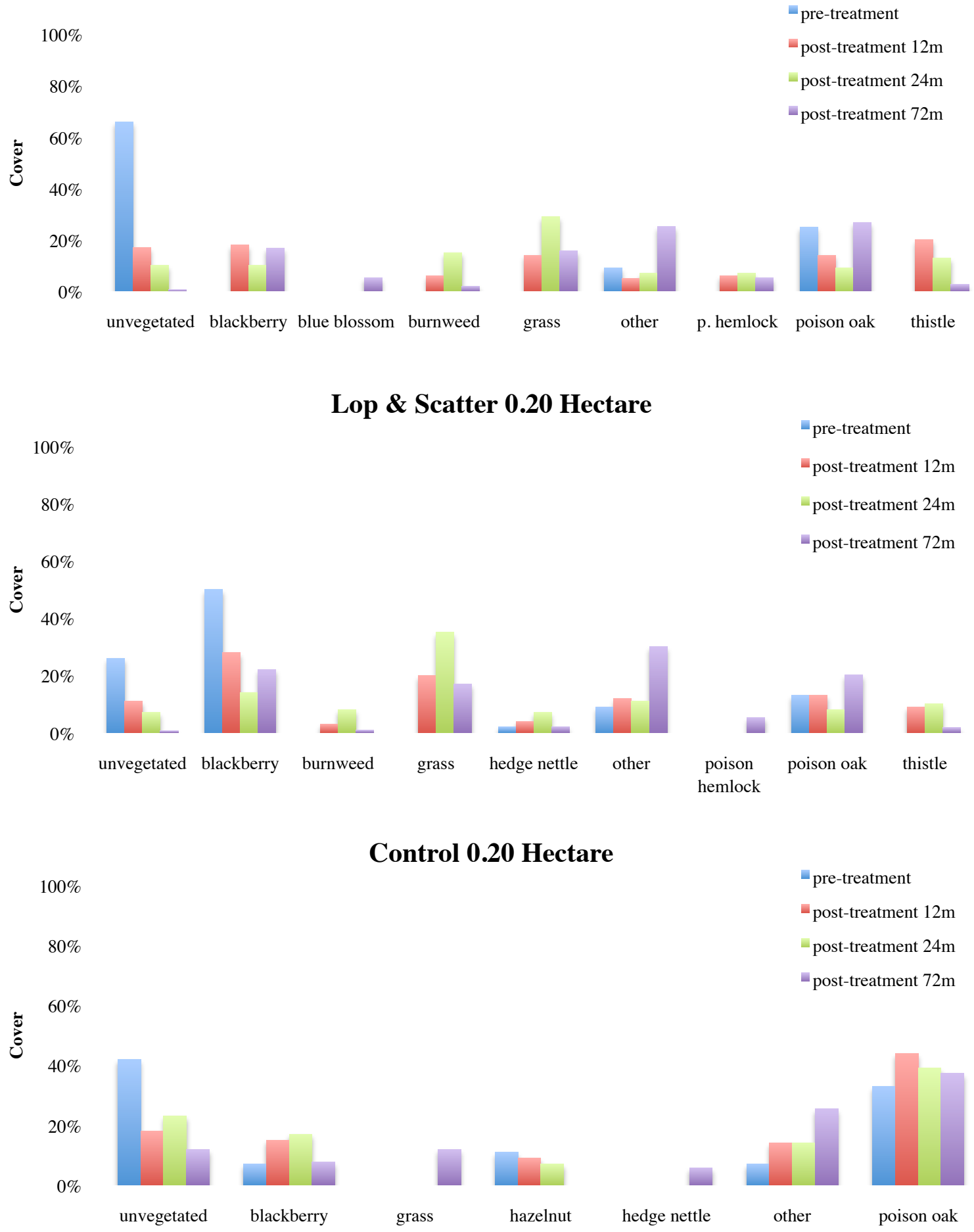

Figure 5. Illustration of summaries for understory vegetation cover $(\%)$ for 0.20 ha plots at pre-, posttreatment 12, 24 and 68m post-treatment. Source: $12 \mathrm{~m}$ data: Wise, 2004; $24 \mathrm{~m}$ data: Pinkerton, 2006; 68m data: Loe. 


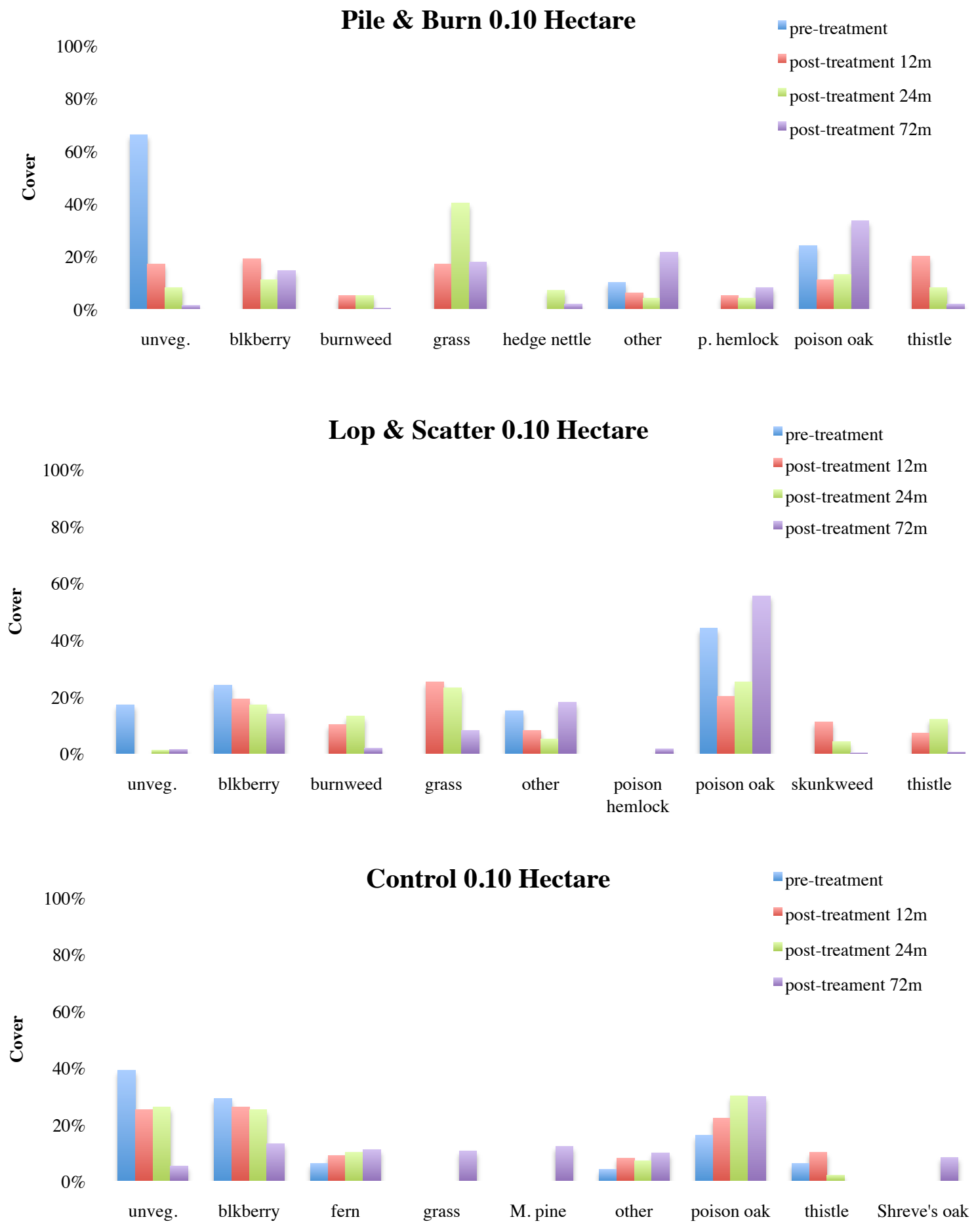

Figure 6. Illustration of summaries for understory vegetation cover (\%) for 0.10 ha plots at pre-, posttreatment 12, 24 and $68 \mathrm{~m}$ post-treatment. Source: $12 \mathrm{~m}$ data: Wise, 2004; $24 \mathrm{~m}$ data: Pinkerton, 2006; 68m data: Loe. 

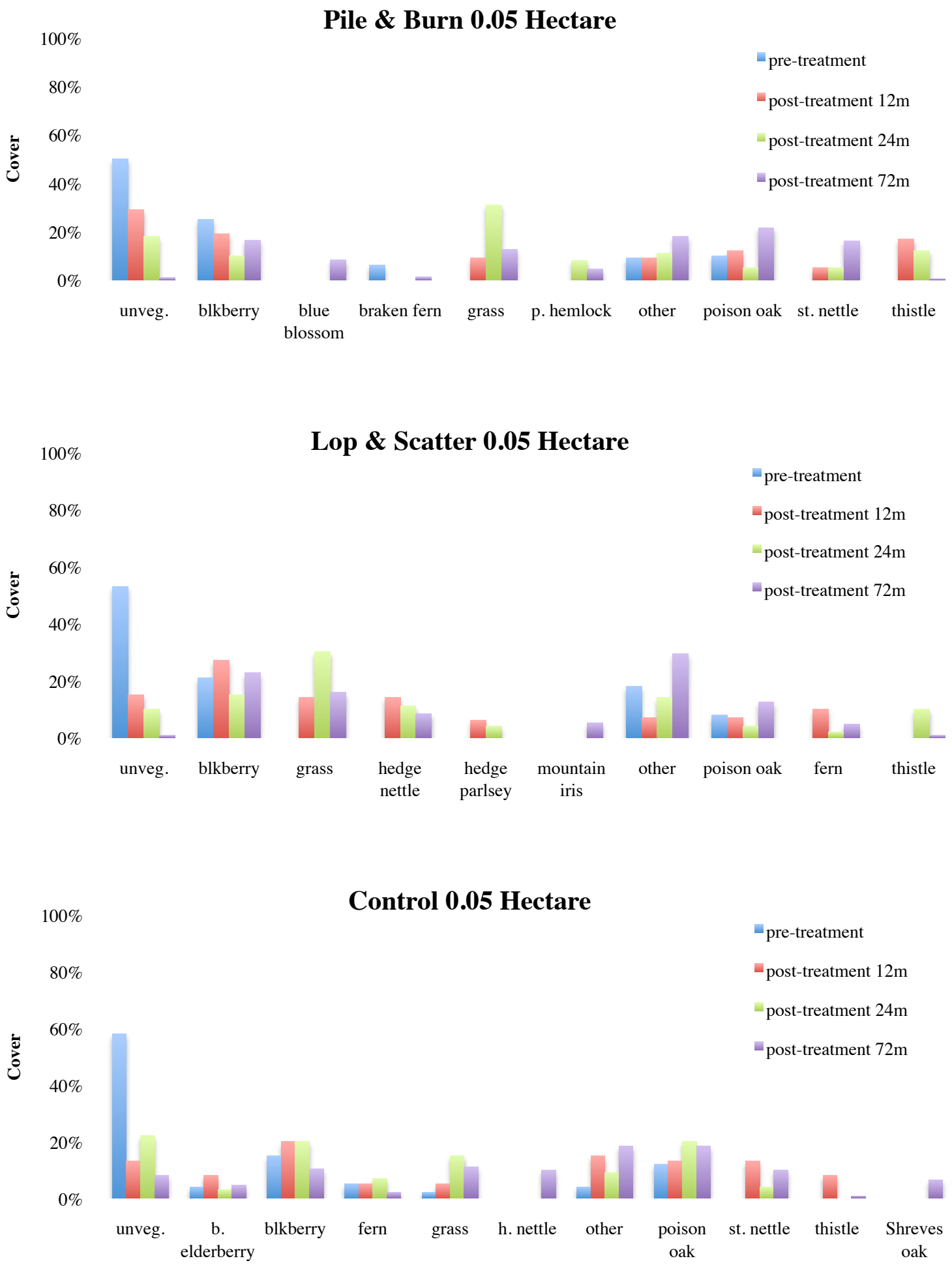

Figure 7. Illustration of summaries for understory vegetation cover (\%) for 0.05 ha plots at pre-, posttreatment 12, 24 and 68m. post-treatment. Source: 12m data: Wise, 2004; 24m data: Pinkerton, 2006; 68m data: Loe. 


\section{Growth of Artificially Regenerated Seedlings}

Please refer to Appendix D for descriptive statistics for all 1119 surviving original trees at 68 months post-treatment. The results are nearly identical to descriptive statistics for growth of sampleseedlings at 68 months post-treatment as seen in Tables 12 and 13. The comparison provides substantiation of the sample's accuracy to the whole set of study's reforested seedlings.

\section{Disease Symptom Occurrence}

Please refer to Figures 8 and 9 for presentation of contingency table results for associations between pitch canker branch-tip symptoms and western gall rust symptoms to independent variables (sitetreatment, gap-size, parent tree, tree height at 68 -months post-treatment, and resistance screening results) as well as to each other. 
Figure 8. Illustration of results from contingency tables for associations between pitch canker branch-tips to independent variables at $68 \mathrm{~m}$ post-treatment.

Pitch Canker x Site Treatment

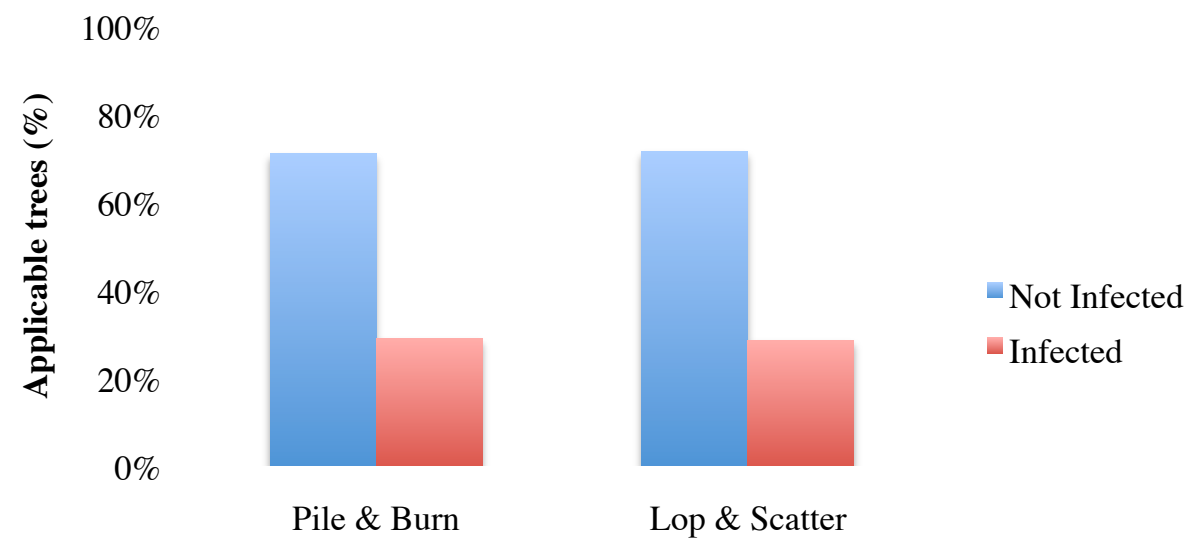

Site Treatment

\section{Pitch Canker x Gap Size}

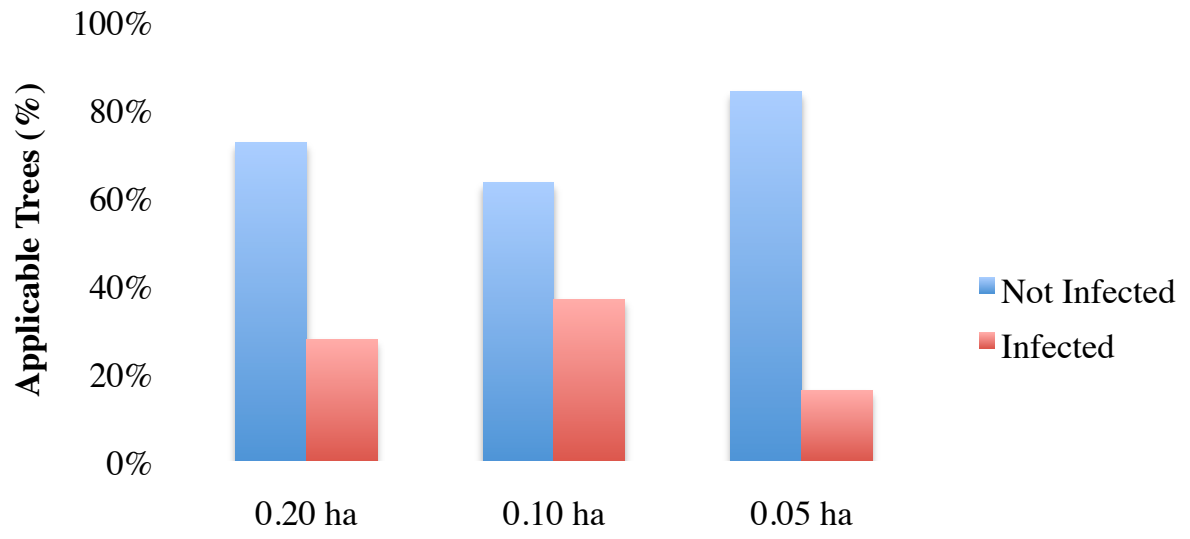

Gap Size 


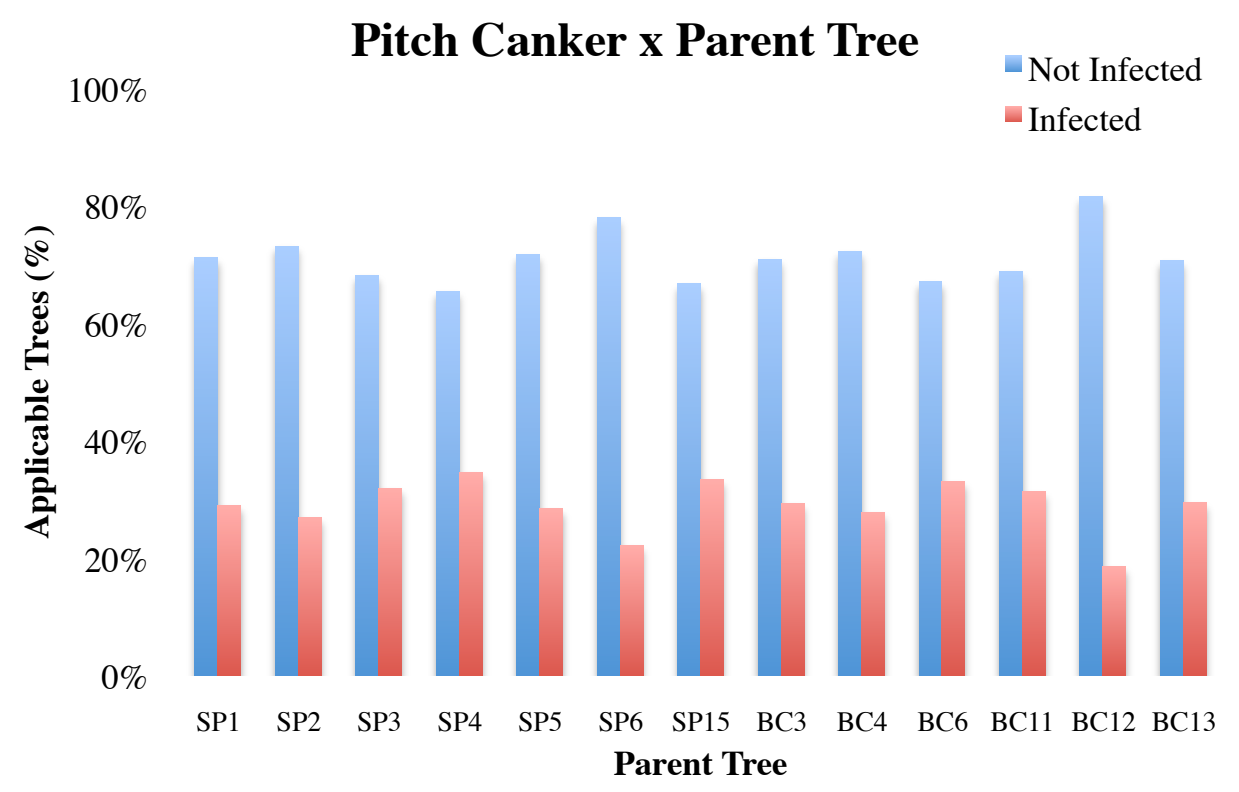

Pitch Canker x Resistance Rating $100 \%$

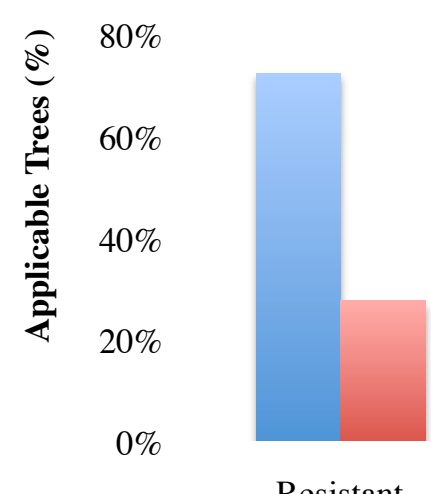

Resistant

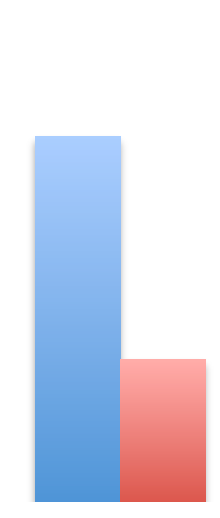

Intermediate
Not Infected

Infected

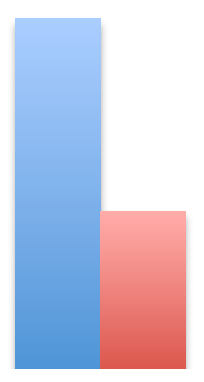

Susceptible 


\section{Pitch Canker x Tree Height}

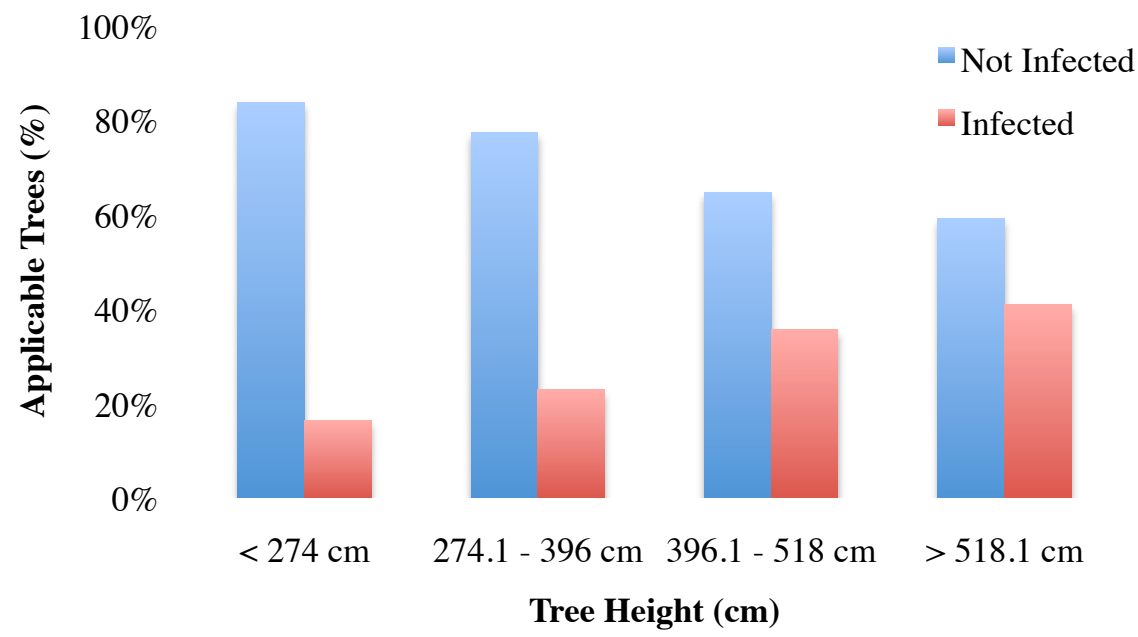

Figure 9. Illustration of results from contingency tables for associations between gall rust symptoms to independent variables and pitch canker branch-tips at $68 \mathrm{~m}$ post-treatment.

\section{W. Gall Rust x Site Treatment}

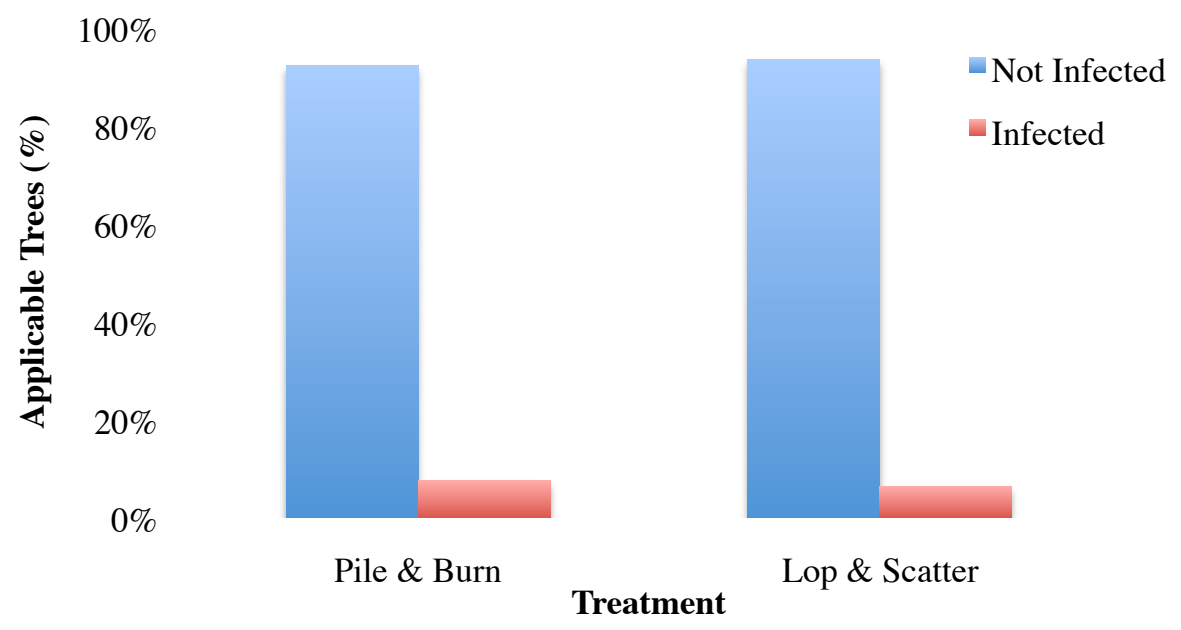




\section{W. Gall Rust x Gap Size}
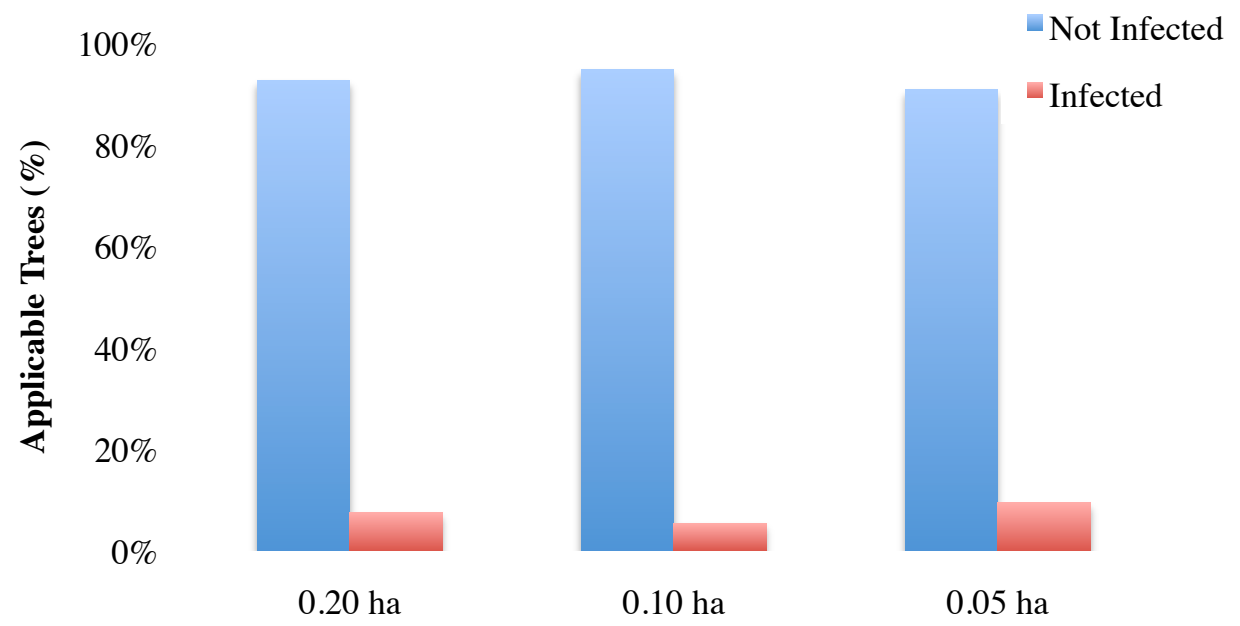

Gap Size

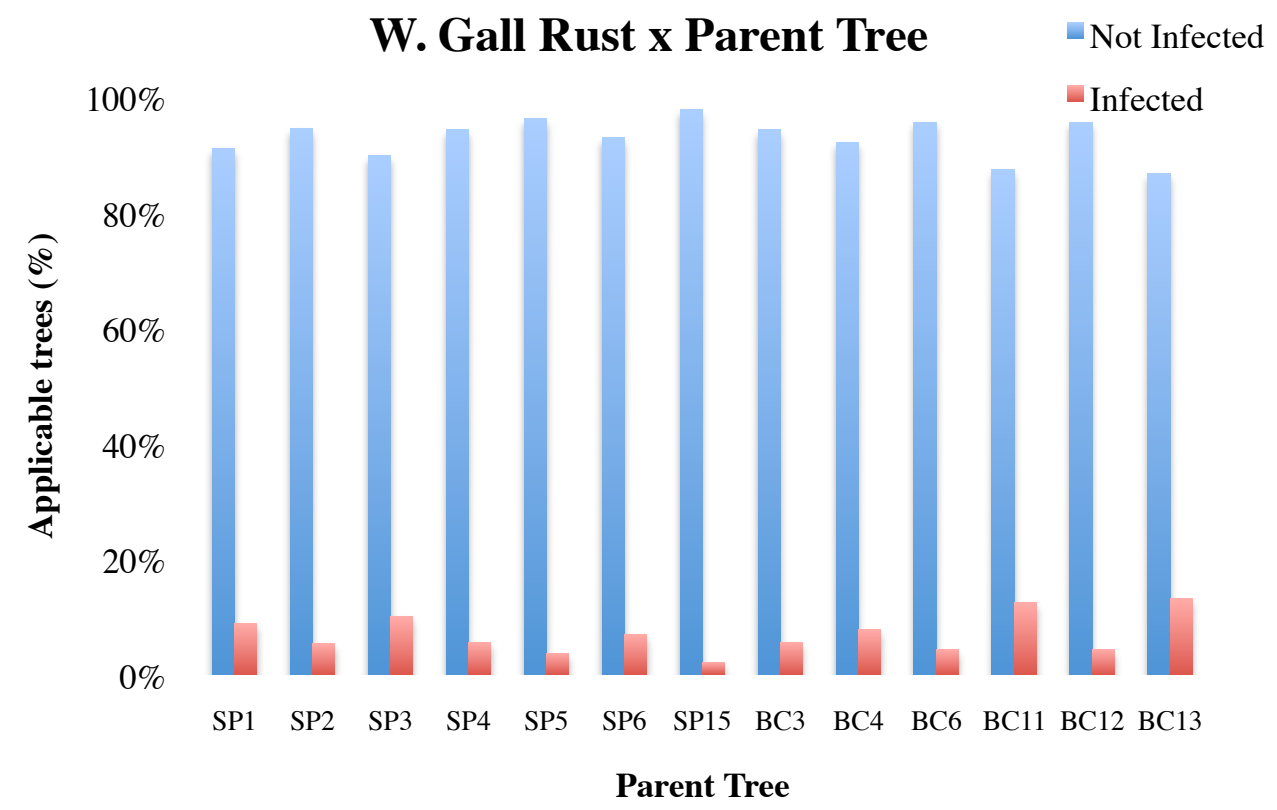


W. Gall Rust x Resistance Rating
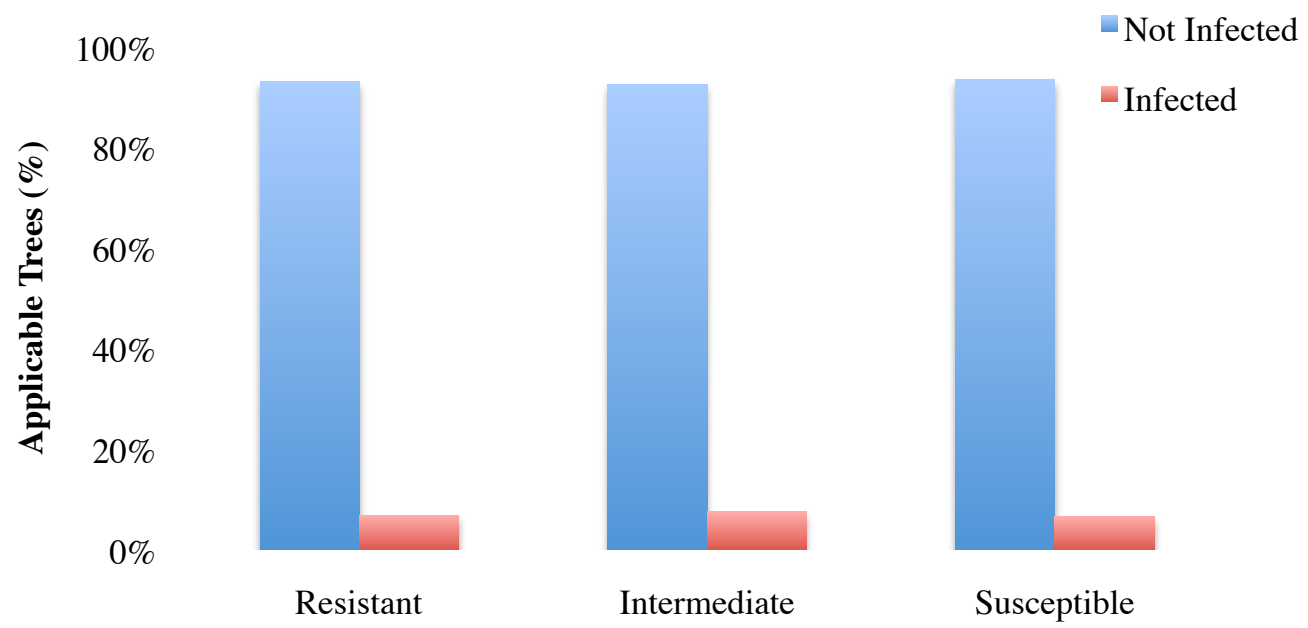

\section{W. Gall Rust x Tree Height}
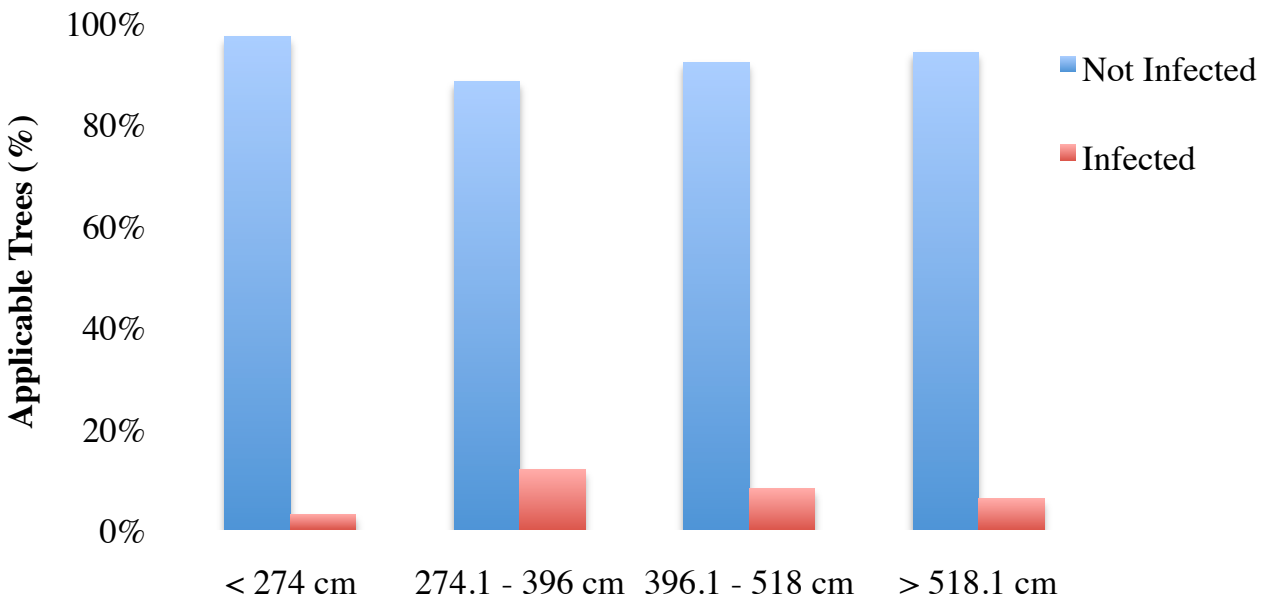

Height Rank 


\section{W. Gall Rust x Pitch Canker}

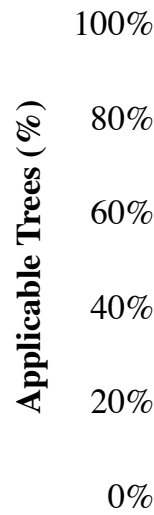

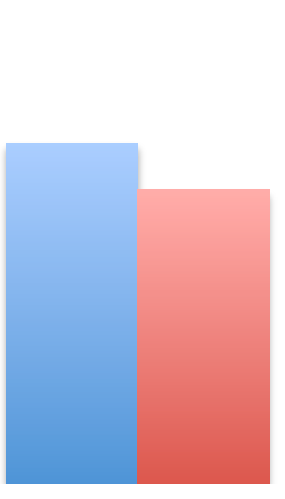

PC -Not Infected

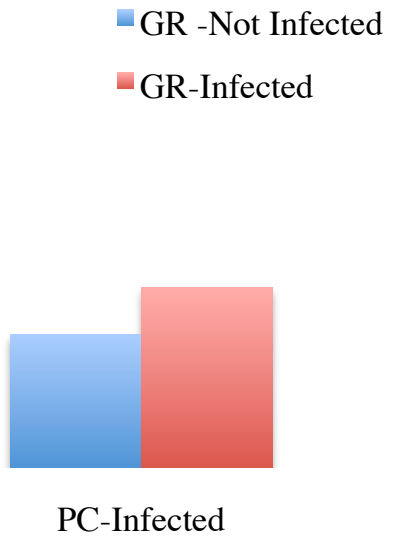

PC-Infected 


\section{Interplanted Seedling Survival and Growth}

As described in the methods section, the interplanted seedlings replaced the 673 seedlings that had died during the 12-months post-treatment with the intention to homogenize the growing conditions (i.e. density and competition) for the remaining original trees. Table 23 shows the range of survival rates for the 8 parent trees used for interplanting (40.7-64.8\%), which support the survival rates resulting from original trees (Table 24). Please note that in Tables 23 and 24 the seedlings were derived from the same parent trees, where the 2 preceding the parent moniker simply indicates an interplanted seedling versus seedlings planted during the original planting session. However, opposite from survival rates yielded by originally planted seedlings, survival rates for lop and scatter gaps $(57.4 \%)$ surpasses the $49.5 \%$ of pile and burn plots. By the end of 68-months post-treatment interplanted seedlings are surviving best in 0.10 -hectare gaps $(62.7 \%$ ) over 0.05 - and 0.20 -hectare gaps (50.3- and $47.4 \%$ respectively) (See Table 25 ).

Table 26 and 27 show the descriptive results for the growth measures of interplanted seedlings. Seedlings in pile and burn gaps yielded slightly larger average heights, whereas diameter averages for the two site-treatments are identical. The 0.20 -hectare gaps yielded the largest height average $(284.8 \mathrm{~cm})$ over 0.10- and 0.05-hectare gaps (280.4- and $225.6 \mathrm{~cm}$ respectively). Yet diameter averages were largest in 0.10-hectare gaps $(43.1 \mathrm{~mm})$, followed by 0.20 - and 0.05 - acre gaps 39.4 - and $25.4 \mathrm{~mm}$ respectively). Growth measures by parent tree show a range of height from $15.24-609.6 \mathrm{~cm}$ and diameter averages from $5.08-106.6 \mathrm{~mm}$. 
Table 23. Survival by parent of interplanted seedlings at $68 \mathrm{~m}$ posttreatment.

\begin{tabular}{|c|c|}
\hline Parent & Survival \% \\
\hline 2BC11 & 64.7 \\
2SP2 & 55.3 \\
2BC6 & 52.3 \\
2BC12 & 47.9 \\
2SP6 & 46.3 \\
2BC3 & 44.1 \\
2BC13 & 41.9 \\
2SP5 & 38.9 \\
\hline
\end{tabular}

Table 24. Survival by parent of original seedlings at $68 \mathrm{~m}$ posttreatment.

\begin{tabular}{|c|c|}
\hline Parent & \%Survival \\
\hline BC11 & 62.22 \\
SP2 & 55.36 \\
BC3 & 52.98 \\
BC6 & 52.22 \\
BC12 & 51.11 \\
SP6 & 47.78 \\
SP5 & 45.00 \\
BC13 & 40.48 \\
\hline
\end{tabular}

Table 25. Survival rates for interplanted seedlings by parent, gap size and treatment $68 \mathrm{~m}$ post-treatment.

\begin{tabular}{|c|c|c|c|}
\hline Group & & $\mathrm{n}$ & $\begin{array}{c}68 \text { Month Survival } \\
\text { Rate }\end{array}$ \\
\hline All & & 673 & 52.9 \\
\hline \multicolumn{4}{|l|}{ Parent } \\
\hline & 2SP2 & 150 & 55.3 \\
\hline & $2 \mathrm{SP} 5$ & 54 & 38.9 \\
\hline & 2SP6 & 54 & 46.3 \\
\hline & 2BC3 & 34 & 44.1 \\
\hline & 2BC6 & 151 & 52.3 \\
\hline & $2 \mathrm{BC} 11$ & 139 & 64.7 \\
\hline & 2BC12 & 48 & 47.9 \\
\hline & 2BC13 & 43 & 41.9 \\
\hline \multicolumn{4}{|c|}{ Gap Size } \\
\hline & $0.05 \mathrm{ha}$ & 81 & 50.3 \\
\hline & 0.10 ha & 237 & 62.7 \\
\hline & 0.20 ha & 355 & 47.4 \\
\hline \multicolumn{4}{|c|}{ Treatment } \\
\hline & Pile \& Burn & 377 & 49.5 \\
\hline & Lop \& Scatter & 296 & 57.4 \\
\hline
\end{tabular}


Table 26. Descriptive statistics for height $(\mathrm{cm})$ of interplanted seedlings at $68 \mathrm{~m}$ post-treatment.

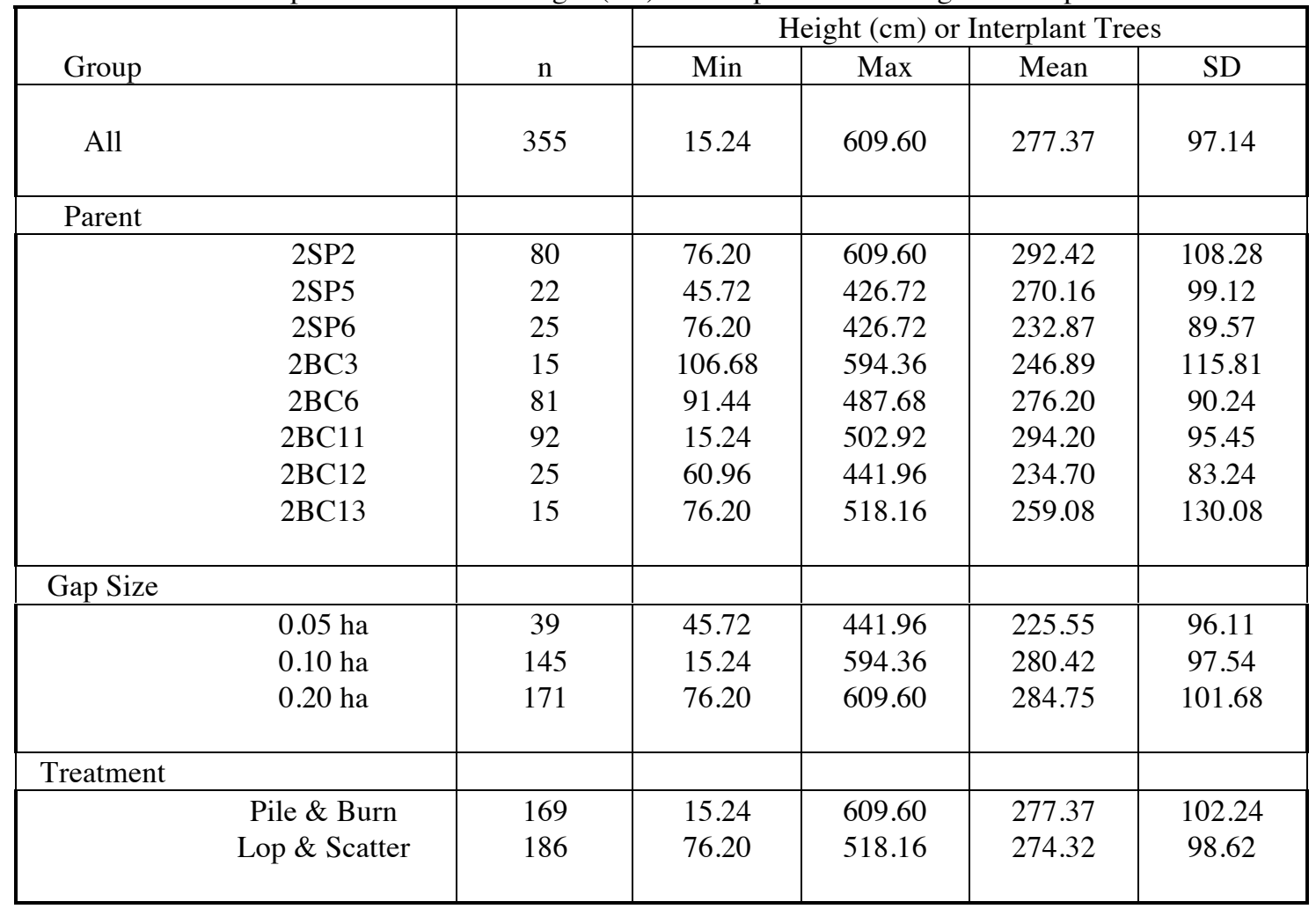

Table 27. Descriptive statistics for diameter $(\mathrm{mm})$ of interplanted seedlings at $68 \mathrm{~m}$ post-treatment.

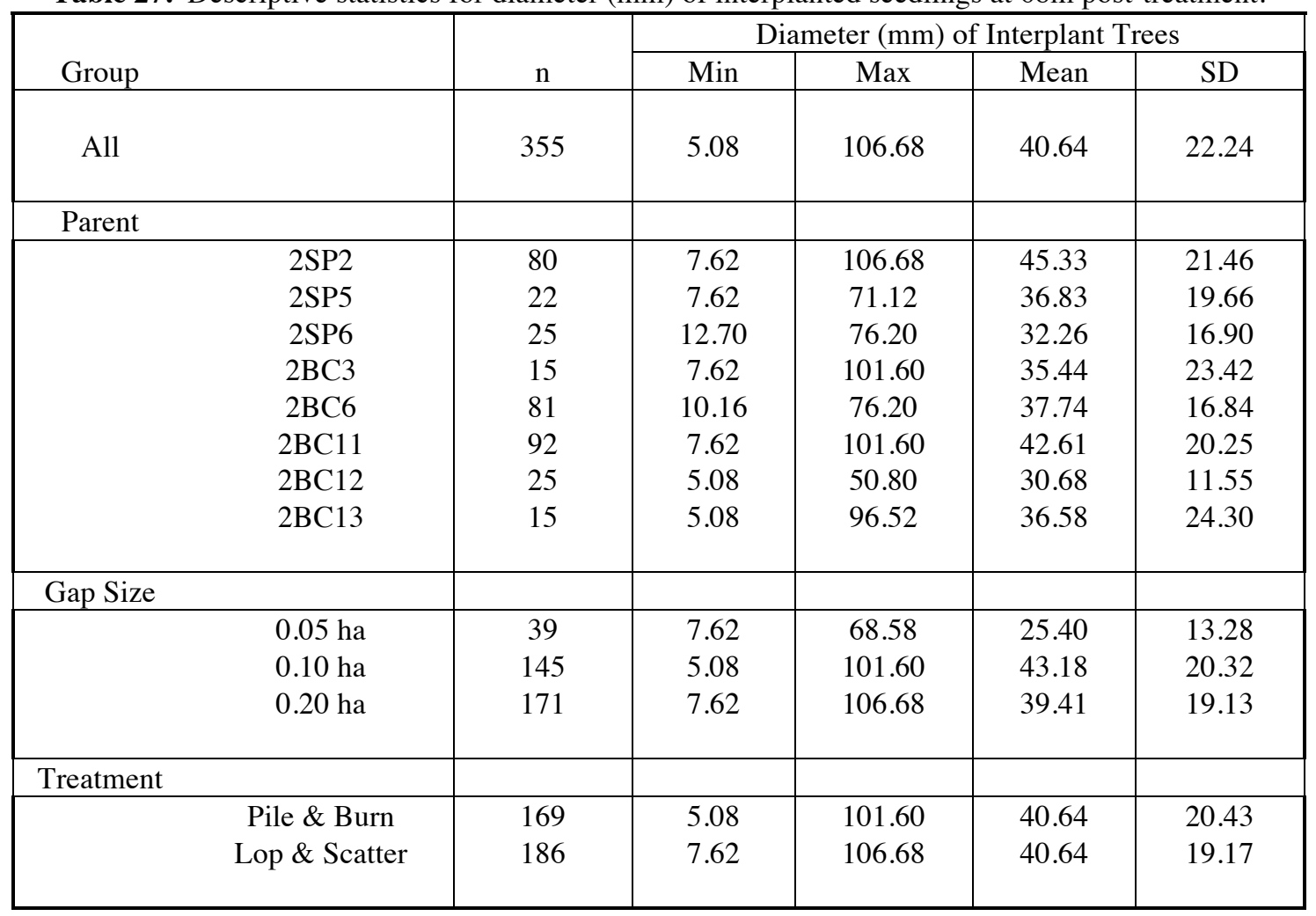




\section{Spatial Relationship}

As outlined in the methods section, this analysis was achieved by creating averages for survival and growth (height) in four quadrants that align with the sun's azimuth at six different times of the year. The statistics were limited to descriptive analysis and were intended to simply determine if there was an observable differential in averages, which may indicate a potentially significant effect on tree performance from an individual seedling's location within the plot. Table 28 shows the survival rates are very similar among quadrants for each analysis period (overall range 49.8- 61.9\%) (both extremes produced by quadrants from the same time period: September 23, 2003). Albeit there is a trend true for all azimuth analyses that seedlings in the $2^{\text {nd }}$ and $3^{\text {rd }}$ Quadrants had the highest chance of survival, followed closely by Quadrant 4, leaving seedlings in Quadrant 1 (receiving the most direct sunlight) with the lowest odds of survival. A contingency table used to assess the association between survival and quadrant for the September $23^{\text {rd }}$ time period provided a significant Pearson Chi-Square value $(\mathrm{p}=0.000)$. Similar to overall survival observation, yet with inversed results, there is a trend apparent within the fairly narrow range of height averages (32.5- 44.5cm) (Table 29). Generally Quadrant 1 or 4 (receiving the most direct sunlight) had the highest average followed by 2, leaving seedlings in Quadrant 3 with the lowest growth performance. 
Table 28. Survival results for spatial analysis for quadrants aligned with the sun's azimuth for 6 days of the year, 2003; 24m post-treatment data. Source: Pinkerton, 2006

\begin{tabular}{|c|c|c|c|c|}
\hline Azimuth* \& Date (2003) & Quadrant & $\mathrm{n}$ & $\begin{array}{l}\text { Surviving } \\
\text { Individuals }\end{array}$ & $\begin{array}{c}\text { Average } \\
\text { Survival rate }\end{array}$ \\
\hline $150.1^{\circ}$ March 20 & $\begin{array}{l}1 \\
2 \\
3 \\
4\end{array}$ & $\begin{array}{l}572 \\
567 \\
570 \\
571\end{array}$ & $\begin{array}{l}298 \\
347 \\
324 \\
323\end{array}$ & $\begin{array}{l}52.1 \% \\
61.2 \% \\
56.8 \% \\
56.6 \%\end{array}$ \\
\hline $141.9^{\circ}$ May 1 & $\begin{array}{l}1 \\
2 \\
3 \\
4\end{array}$ & $\begin{array}{l}575 \\
567 \\
566 \\
572\end{array}$ & $\begin{array}{l}289 \\
349 \\
324 \\
330\end{array}$ & $\begin{array}{l}50.3 \% \\
61.6 \% \\
57.2 \% \\
57.7 \%\end{array}$ \\
\hline $126.9^{\circ}$ June 21 & $\begin{array}{l}1 \\
2 \\
3 \\
4\end{array}$ & $\begin{array}{l}575 \\
564 \\
567 \\
574\end{array}$ & $\begin{array}{l}289 \\
344 \\
329 \\
330\end{array}$ & $\begin{array}{l}50.3 \% \\
61.0 \% \\
58.0 \% \\
57.5 \%\end{array}$ \\
\hline $134.0^{\circ}$ August 1 & $\begin{array}{l}1 \\
2 \\
3 \\
4\end{array}$ & $\begin{array}{l}568 \\
566 \\
571 \\
575\end{array}$ & $\begin{array}{l}299 \\
346 \\
326 \\
321\end{array}$ & $\begin{array}{l}52.6 \% \\
61.1 \% \\
57.1 \% \\
55.8 \%\end{array}$ \\
\hline $155.7^{\circ}$ September 23 & $\begin{array}{l}1 \\
2 \\
3 \\
4\end{array}$ & $\begin{array}{l}570 \\
570 \\
570 \\
570\end{array}$ & $\begin{array}{l}284 \\
353 \\
329 \\
326\end{array}$ & $\begin{array}{l}49.8 \% \\
61.9 \% \\
57.7 \% \\
57.2 \%\end{array}$ \\
\hline $162.5^{\circ}$ December 22 & $\begin{array}{l}1 \\
2 \\
3 \\
4\end{array}$ & $\begin{array}{l}570 \\
570 \\
570 \\
570\end{array}$ & $\begin{array}{l}303 \\
346 \\
327 \\
316\end{array}$ & $\begin{array}{l}53.2 \% \\
60.7 \% \\
57.4 \% \\
55.4 \%\end{array}$ \\
\hline
\end{tabular}

* Azimuth of sun at 12:00pm

Source: USNO Astronomical Applications Dept., 2009 
Table 29 Height $(\mathrm{cm})$ results from spatial analysis for quadrants aligned with the sun's azimuth for 6 days of the year, 2003; 24m post-treatment data. Source: Pinkerton, 2006.

\begin{tabular}{|c|c|c|c|c|c|c|c|}
\hline \multirow{2}{*}{$\begin{array}{c}\text { Azimuth* \& Date } \\
(2003)\end{array}$} & \multirow{2}{*}{ Quadrant } & \multirow{2}{*}{$\mathrm{n}$} & \multicolumn{5}{|c|}{ Height $(\mathrm{cm})$} \\
\hline & & & Minimum & Maximum & Average & Sum & $\mathrm{SD}$ \\
\hline \multirow[t]{5}{*}{$150.1^{\circ}$ March 20} & & & & & & & \\
\hline & 1 & 49 & 12.00 & 223.50 & 79.43 & 3892.10 & 42.76 \\
\hline & 2 & 66 & 17.90 & 166.00 & 79.20 & 5227.20 & 40.89 \\
\hline & 3 & 88 & 12.80 & 159.40 & 70.76 & 6226.70 & 32.78 \\
\hline & 4 & 68 & 17.50 & 158.00 & 81.84 & 5565.00 & 38.89 \\
\hline \multirow[t]{5}{*}{$141.9^{\circ}$ May 1} & & & & & & & \\
\hline & 1 & 49 & 17.50 & 223.50 & 83.50 & 3924.70 & 43.52 \\
\hline & 2 & 66 & 12.00 & 166.00 & 74.84 & 5238.70 & 40.18 \\
\hline & 3 & 88 & 12.80 & 163.40 & 74.42 & 6474.70 & 34.70 \\
\hline & 4 & 68 & 18.30 & 158.00 & 78.70 & 5272.90 & 37.28 \\
\hline \multirow[t]{5}{*}{$126.9^{\circ}$ June 21} & & & & & & & \\
\hline & 1 & 49 & 17.50 & 223.50 & 85.35 & 3414.00 & 44.56 \\
\hline & 2 & 66 & 12.00 & 166.00 & 74.51 & 5811.50 & 39.91 \\
\hline & 3 & 88 & 12.80 & 163.40 & 75.43 & 6336.20 & 34.94 \\
\hline & 4 & 68 & 18.30 & 158.00 & 77.53 & 5349.30 & 36.78 \\
\hline \multirow[t]{5}{*}{$134.0^{\circ}$ August 1} & & & & & & & \\
\hline & 1 & 49 & 17.50 & 223.50 & 83.88 & 3522.80 & 44.48 \\
\hline & 2 & 66 & 12.00 & 166.00 & 75.04 & 5702.70 & 39.99 \\
\hline & 3 & 88 & 12.80 & 163.40 & 74.20 & 6604.20 & 34.78 \\
\hline & 4 & 68 & 18.30 & 158.00 & 79.40 & 5081.30 & 36.95 \\
\hline \multirow[t]{5}{*}{$155.7^{\circ}$ September 23} & & & & & & & \\
\hline & 1 & 49 & 12.00 & 223.50 & 82.01 & 4346.40 & 43.62 \\
\hline & 2 & 66 & 17.90 & 163.40 & 75.24 & 5191.30 & 38.85 \\
\hline & 3 & 88 & 12.80 & 159.40 & 71.19 & 5909.00 & 33.06 \\
\hline & 4 & 68 & 17.50 & 158.00 & 82.79 & 5464.30 & 39.05 \\
\hline \multirow[t]{5}{*}{$162.5^{\circ}$ December 22} & & & & & & & \\
\hline & 1 & 49 & 12.00 & 223.50 & 81.06 & 4296.40 & 43.70 \\
\hline & 2 & 66 & 17.00 & 163.40 & 75.64 & 5446.30 & 38.93 \\
\hline & 3 & 88 & 12.80 & 159.40 & 70.10 & 6098.50 & 32.58 \\
\hline & 4 & 68 & 17.50 & 158.00 & 85.93 & 5069.80 & 39.14 \\
\hline
\end{tabular}

* Azimuth of sun at 12:00pm

Source: USNO Astronomical Applications Dept., 2009) 


\section{DISCUSSION}

\section{Understory Vegetation}

Through the 72 months since treatment, the evolution in understory cover can be characterized by sustained growth, consistent presence of few specific species, and changes in cover proportion. The most notable changes have been discernable swells in cover percentage of weedy and grass species, a dramatic decrease of unvegetated areas, and the continued increase of species diversity and poison oak.

At 12-months post-treatment an abundance of weedy species (e.g. bull thistle, burnweed and wild oat (Avena fatua L.); unseen in pre-treatment plots) was attributed to 1) canopy removal combined with exposure of bare soil, 2) pre-existing plot conditions, and 3) close proximity to rangelands. By 24-months post-treatment the cover of weedy species had diminished. However, this reduction was counterbalanced by a dramatic jump in cover of grass species. The increased proportion of grass seen at 24-months posttreatment $(23 \%)$ was reduced to $13 \%$ by 68 -months post-treatment. Considering these two categories encountered similar reversion from understory abundance back towards original trace occurrence, it appears they could be sequential sere in the allogenic succession of the study-site.

Conversely, unvegetated space within the study area has decreased substantially since sitetreatment. Throughout the study-site, the amount of litter and bare ground has decreased from $45 \%$ to $3 \%$ in the 68 months since treatment. This change can be accounted for by the increase of poison oak and species diversity.

Overall, poison oak in the study-site has gradually increased over the 68-months post-treatment from 21 to $28 \%$. In all but 0.20 - and 0.10 -hectare control plots, the cover percent of poison oak had surpassed the percentage recorded at any of the previous surveys. 0.20 -hectare control plots are the only category that experienced a decrease in cover by the species. The 0.10 -hectare, lop and scatter gaps had the highest percentage of poison oak cover recorded (nearly 60\%). Although abundant in the pre-treatment study site, the cover of poison oak at 68-months shows an unprecedented dominance of the understory. This may be due to a variety of factors such as: 1) a positive reaction to the disturbance caused by sitetreatment, 2) the species' ability to survive in a variety of moisture and sun intensities, 3) and the species' 
suppression capability. In full sun these plants can develop into a dense shrub 1-6' high with a wide-spread root system, suppressing nearby species (DiTomaso and Lanini, 2009).

Species diversity, encompassing the 'other species' category and the introduction of new species (species not recorded in previous survey-summaries) has increased across the study site, including control plots. Appearances of species such as blue blossom in pile and burn gaps, mountain iris in the 0.05-hectare lop and scatter gaps, and poison hemlock in 0.20- and 0.10-hectare lop and scatter gaps could be the result of several factors: 1) increased human, animal and treatment activity within the study site, 2) random or episodic germination and establishment of seeds (residual or from adjacent stands) as light, moisture, and competition levels change within the plot, and 3) close proximity to grazed rangeland.

The species that have increased or maintained presence in the understory vegetation appear to be the ones that can survive on very little unvegetated space and withstand the domination of the Monterey pine seedlings, poison oak, and other well established individuals.

\section{Natural Regeneration}

In hopes of sustaining a population, reproduction for any species is paramount. With pretreatment regeneration proportion favoring hardwoods $(79 \%)$ rather than softwoods $(21 \%)$, the outlook seemed dismal for Monterey pine within the Scott's Creek Management unit (Wise, 2004). Without fire or small-scale disturbances, studies indicate that this stand could evolve from a Monterey pine to a Coast Live/Shreve oak forest type (Piirto and Valkonen, 2005).

However, by 24 months post-treatment, the chances for natural regeneration pines appeared to be increasing. Survey of the naturally occurring seedlings at the understory level showed softwood species composition within the study-area had risen $21 \%$, totaling $42 \%$. Pre-treatment, Monterey pine seedlings comprised only $8 \%$ of species composition, yet by 24 -months post treatment, that percentage had more than quadrupled (38\%). These results are not conclusive yet encourage further research and breed hope for restoration of this native stand.

Naturally occurring Monterey pine seedlings within the treated gaps at 68 months post-treatment show that although the difference may not be significant, pile and burn gaps produce more than lop and scatter plots or control plots (47.2-, 43.4- and 9.4\%, respectively). This result is expected, where Monterey 
pines are known to prefer the conditions left by a fire occurrence (e.g. bare soil, cleared competition). The differences in regeneration success are a bit harder to interpret for gap-size. Although it is clear that 0.05 hectare plots in the study produced a significantly fewer amount of regeneration trees, it must be considered that 0.05 -hectare plots are one one-fourth the size of 0.20 -hectare plots. Thus, the former actually produced more trees/hectare than the latter. Overall by 68 months post-treatment, the 0.10 -plots produced the most naturally occurring Monterey pine seedlings per hectare.

The small number of naturally occurring seedlings by 0.05 -hectare gaps at 68 months posttreatment can be attributed to: 1) a lack of necessary sunlight resulting from the small gap-opening, and 2) the edge-effect is smaller for the inferior gap-sizes and thus the plot is less heavily exposed to seeds from adjacent trees. The proportionately few naturally occurring seedlings in 0.20 -hectare plots could be accredited to: 1) trees of 0.20 -hectare plots are taller and thus block light from germinating and establishing seedlings, on the other hand, 2) the species' regeneration success is somehow hampered by the longer exposure to sunlight allowed by a larger canopy gap, or 3) the longer exposure to sunlight allowed for a quick development of understory vegetation that prevented seedling germination and establishment. The 0.10-hectare gap-size may be just right in regard to elemental exposure.

When considering the results produced at 24-month post-treatment for the percentage of naturally occurring Monterey pine seedlings within the inner, middle, or outer rings of the circular plots, it is hard to say how much these numbers can be relied upon. With the fairly young (i.e. sexually immature) seedlings in the gaps, the seeds that have germinated are most likely residual seeds that were waiting for ideal conditions or are from mature trees adjacent to the plot. If the latter is true, then it is to be expected that a higher density of seedlings will be closer to the edge of the plot. More time and further research will be needed to conclusively address this variable.

\section{Survival of Artificially Regenerated Seedlings}

With the goal of restoring a strong population of Monterey pine in native stands, high odds of survival of artificially regenerated seedlings is fundamental. Results from 68-month post-treatment survey show that indeed, there is an advantage to preparing planting sites with a pile and burn treatment. As discussed above in regards to natural regeneration, higher rates of survival are expected since we are 
dealing with a species that is specifically adapted for post-fire occurrence establishment. The bare soil, elimination of competition, increased availability to nutrients (e.g. calcium and phosphorous) and sun exposure in sites has given seedlings in the study a $51.7 \%$ better chance of survival over seedlings in the lop and scatter plot (p-value=0.066) (Wise, 2004).

The lower survival odds of seedlings in lop and scatter plots can be accredited to several factors, most of which are a result of the remaining slash layer: 1) remnant fungal inoculums (e.g. pitch canker) in slash, 2) decreased nutrients lost to decomposition of slash (e.g. nitrogen), 3) increased moisture and temperature of soil due to blanket of slash, 4) decreased sun exposure to seedlings, and lastly, 5) the lesser degree of site-disturbance in comparison to pile and burn plots (Wise, 2004; McDonald \& Laacke, 1990). Although a layer of slash may slow the growth of weedy or shade intolerant competition-species, the thicker layer of biomass effectively acts against the seedlings' growth preferences (e.g. full sun, bare soil, and minimal competition) to discourage establishment and ultimately survival (Gotou \& Nishimura, 2003; McDonald \& Laacke, 1990).

Survival results yielded in the three gap-sizes do not conclusively suggest that any one gap-size is significantly beneficial for survival odds of artificially regenerated seedlings. The results seen at 68-month post-treatment do not correspond to results seen at 12- and 24-months post-treatment. In fact the gap-size with the lowest average survival rate (0.10-hectare plots) in previous surveys now shows superior rates over the other two gap-sizes. At 12-months post-treatment, low survival in 0.10-hectare gaps was partially attributed to cattle damage. By 24-month survey, animal effects (e.g. cattle, deer and feral pig) were distributed between all plots and thus no longer inflicted uncontrolled influence upon 0.10-hectare gaps (Pinkerton, 2006). This may consequently explain the reversal in survival rates among gap sizes.

Survival analysis of seedlings from the 13 parent-trees shows a fairly wide range of rates. The offspring from parent SP15 (screened 'highly susceptible' to pitch canker) have consistently been the least likely to survive since project inception. Similarly, seedlings from parent trees BC11 and SP2 (screened 'resistant' to pitch canker) represent two of the top three survival rates. These results could indicate either a relationship between screening-results and seedling survival or marks overall phenotypic hardiness of an individual. However, this trend is not consistent among comparisons for all parent tree results. Further studies may conclusively decipher whether or not a relationship exists between survival rates and pitch 
canker resistance. Survival rates also show no observable pattern of between parents sourced from Swanton Pacific Ranch and Big Creek Lumber's portion of the Año Nuevo stand.

\section{Growth of Artificially Regenerated Seedlings}

Results from tested predictor variables show observable, and sometimes dramatic, impacts upon height and diameter of sample-seedlings $(n=271)$ at 68 -months post-treatment. Note the growth data for all surviving original seedlings $(\mathrm{n}=1119)$ show nearly identical performance averages overall and by treatment, gap-size, and parent, substantiating the validity of sample-set's results. Pile and burn gaps generated the largest growth averages of the two site-treatments, yet not with statistical significance. Reasoning discussed for superior survival rates in pile and burn gaps (e.g. optimal soil temperature, soil moisture, and sun exposure due to minimal duff), may explain the higher growth means over those of lop and scatter gaps (McDonald \& Laacke, 1999).

Most notable was the relationship between growth averages in gap-sizes, specifically between 0.20- and 0.05-hectare gaps. 0.20-hectare gaps yielded seedlings with a significantly larger height and diameter averages over the mean measures yielded 0.05 -hectare gaps ( $\mathrm{p}$-values $=0.027$ and 0.0081 respectively). As well, the diameter averages in 0.10-hectare gaps were deemed significantly larger than that yielded by 0.05 -hectare gaps (p-value=0.047). The differences between growth averages yielded in 0.20- and 0.10-hectare gaps are nominal, indicating very little variability between these two gap-sizes.

Seedlings in 0.20-hectare gaps, once established, may have superior growth averages due to more abundant sunlight, creating an optimal balance of temperature, moisture and exposure conditions.

Additionally, there may be an element of decreased competition when considering the nominal differences in growth between seedlings in 0.20 - and 0.10 - acre gaps. Superior survival results in 0.10 -hectare gaps translate to a higher density of trees competing for water, nutrients and sunlight. Thus, trees in 0.20 -hectare gaps may have a better chance to flourish as a result of a mortality-induced decrease in seedling density (McDonald \& Laacke, 1999).

The 13 parent trees produced a dramatic range of growth averages (both height and diameter). Consistently through the study the same parents hover at the top of the range and others at the bottom. 
Albeit, not statistically significant, this information warrants attention and further research as choices are made for plantation plantings when yield is critical.

\section{Disease Symptom Occurrence}

With the first detection of disease symptoms during the 68-months post-treatment survey, several initial observations can be made regarding infection rates. Albeit not statistically significant, infection rates indicate a range of susceptibility among the 13 parent trees (18.4- 33.3\%). These in-field results imply a variation in genetically-linked disease defenses, yet they do not support resistance-screening results (Table 2), nor do they correlate to survival rates by parent tree (Table 8). The lack of an observed pattern between in-field infection results to resistance ratings is reinforced by the insignificant Pearson Chi-Square value (pvalue $=0.545$ ). The dissimilarity between infection and survival rankings by parent may be accredited to fatal infections that went unaccounted for (cause of death was not investigated for 'dead' or 'missing' seedlings) skewing detected infection rates. The dissimilarity between infection rates and resistance ratings may be accredited to the fact that mother tree was the only parent controlled for, where pollen source may have been effective in ultimate resistance. Further research is needed to determine whether screening methods outlined by Gordon et. al (1998) are appropriate for prediction of infection resistance.

Descriptive analysis indicated a significant relationship between pitch canker incidence (as represented by detection of symptomatic branch tips) to gap-size and tree height. The explanation for these two relationships may be one in the same. Considering the larger growth averages in 0.20 - and 0.10 - acre gaps, trees in these gaps may experience higher rates of infection due to the increased amount of surface area, translating to an increased opportunity for wounding and infection occurrence. It is also possible the environmental conditions in these gaps (e.g. increased exposure to sun, rain, wind) could exacerbate spore dispersion and/or wounding agents. Surprisingly, no relationship is detected between site-treatment and pitch canker incidence, possibly suggesting that unsterilized biomass in lop and scatter plots does not put seedlings at greater risk of infection over those in pile and burn plots. However, it is more likely that a relationship exists yet was not detected due to low survival rates of trees in lop and scatter plots, where seedlings were fatally infected and therefore not accounted for by 68 month post-treatment disease survey. 
Also notable is the difference between overall rates for less severe infection (e.g. symptomatic branch tips; $28.7 \%$ ) and for more advanced infection (e.g. stem and branch canker; 5.32\%). This dramatic contrast aligns with previous observation that pitch canker initially effects many trees in stand prior to advanced development in individual trees (Storer et. al, 2002).

Western gall rust has a less profound impact on the seedlings in the study site, however, it is important to mention the significant relationship determined in the descriptive analysis between pitch canker and gall rust symptoms. These results may simply confirm that trees infected by one disease are predisposed for attack from other pests or pathogens. But the question to ask: is there a lesson to be learned regarding detection or management of pitch canker from this relationship?

\section{Interplanted Seedling Survival and Growth}

Inclusion of interplanted seedlings was not intended to provide information critical to study conclusion, however several observations should be noted. In reference to seeding survival it is interesting that in spite of the 12 months of different growing conditions (i.e. original seedlings in study-site gaps versus interplant seedlings in Swanton Pacific Ranch's shade house) the survival rates for each parent tree is very similar between original and interplanted individuals. These results may indicate that variation in growing environment (e.g. moisture consistency, soil composition, elemental exposure) is less influential than parental genetics for seedling survival.

Conversely to survival results of original seedlings, interplanted seedlings in lop and scatter plots had a better chance to survive than in pile and burn plots. This may be accounted for by the congruous outplanting of interplanted seedlings, simultaneous with a delayed release of nutrients as the slash in lop and scatter gaps decomposed. In spite of the grubbing necessary to successfully plant the interplanted seedlings, the abundance of invasive weed species (i.e. thistle) seen by 12 months post-treatment in pile and burn plots may have hampered establishment and subsequently survival rates of interplanted seedlings in these plots. Similarly, the ranking of gap-sizes by survival rates (in ascending order: 0.10-, 0.05-, and 0.20acre gaps) for interplanted seedlings is unlike results seen for original trees at either 12-, 24- or 68- month surveys. However, the 68-month post-treatment survey of original trees showed seedlings in 0.10 -hectare 
gaps had the best chance for survival, thus indicating that with more time the interplant and original seedlings may eventually exhibit corresponding survival rates in regard to gap-size.

Growth results for interplanted seedlings at 68-months post-treatment (56 months post-outplanting) show some similarities and some differences to those seen from original sample seedlings. Similarities to original data include height advantages observed in pile and burn gaps and identical rankings of gap-size by growth averages. Both original and interplant data show averages for seedlings in 0.20hectare gaps to be slightly superior in growth measures (i.e. height and diameter) over 0.10-hectare gap averages, and dramatically superior over growth averages for 0.05-hectare gaps.

Differences from original data include noticeably smaller growth averages of interplanted trees and inconsistencies between rankings of parent tree by growth averages. Collectively, interplanted seedlings have height and diameter averages only 69.8- and 60\% (respectively) of the averages determined for original sample trees. This may indicate that potential changes in growth measures may be hampered by: 1) the growing conditions (e.g. growing space, sun exposure) during establishment and the first years of growth, or 2) one less growing season to adapt to out-planted growing. Differences in parent rank by for growth further supports the need for subsequent research to understand the genetic phenomenon behind variability. However, survey in 5, 10, or 15 years may indicate that with time growth averages (overall and by parent) will homogenize and what was observed at 68-months post-treatment was simply a step on the road to eventual congruency.

\section{Spatial Relationship}

Observable trends exist in azimuth analyses for survival and growth performance, yet for the most part the ranges are fairly narrow, suggesting that more advanced statistical models would determine insignificant effect. Preliminary analysis of the time period exhibiting the largest range in survival rates among quadrants (September 23, 2003) shows the contrary where the association is significant. It appears that direct sunlight (e.g. as received by Quadrant 1) or environmental effects of direct sunlight (e.g. warmer soil) is conducive to increased growth averages yet also increases mortality rates. Further research may provide useful insight into the association between seedling performance (i.e. survival and growth), 
contributing to the knowledge base for development of a management plant for native Monterey pine stands.

\section{Limitations}

\section{Study Design}

In hopes of developing management guidelines for Monterey pine, existing real-world restraints were considered in the experimental design. Conducting the experiment in-lab would have had some benefit, however results derived under actual conditions would be most applicable to the native stands. Most notable are the limitations presented by California Forest Practice Rules, environmental politics, project budget, ecological integrity, and operational environment (Wise, 2004).

Elements of the study design (e.g. gap-sizes and site-treatment) were determined by the high standards and restrictions implicated from California Forest Practice Rules for the Southern Sub-district of the Coast Forest District and the California Coastal Commission (Wise, 2004). Specifically, Section 913.8 (b)(2) (limiting the removal of any tree to 0.5 acre (0.202 ha) small group openings), Section 917.4 (a) (allowing for chipping, removing, piling and burning, and lop and scatter of logging slash), Section 917.4 (d) (prohibiting the use of broadcast burning as a site-preparation treatment), and designation of the Año Nuevo highlands a Special Treatment Area (by the California Coastal Commission) provided a base of limitations on which the study was designed. In opinion of members of the team, higher survival and growth rates may result from larger gaps and/or from site-preparation treatments such as broadcast burning (where more surface area directly receives benefit of fire-occurrence) however, in order to be legitimate for landowners in this region, our study needed to abide by the afore-mentioned constraints as well as further legal confines outlined in Wise, 2004.

Restricted by ecological integrity and budget, control plots only positively control for understory vegetation and natural regeneration, not for seedlings survival, growth, or disease occurrence. The expenditure of money, natural resources (e.g. seedlings), and manpower seemed an unwise choice.

Considering the remaining dense vegetation (i.e. poison oak, California blackberry, etc.) and closed canopy 
in many of the control plots, widespread mortality of the shade-intolerant Monterey pine seedlings was expected. As well, planting in these conditions would be precarious for crews and equipment. Thus, it was decided that only treated gaps would be evaluated for seedlings' measures. Subsequently, this choice is supported by the low growth averages recorded in 0.05 -hectare plots as they indicate the meager responses of Monterey pine seedlings growing with limited sun exposure.

Finally, operational limitations (e.g. available acreage) bound the number of plots allowed for the study-design. If more space were allocated to the study, inclusion of more replications (i.e. more plots) would extend the statistical precision. Ultimately this means that differences among predictor variables needs to be quite large to be detected by statistical analysis.

\section{Environmental Conditions}

In-field studies must assume inexplicable environmental elements and events could influence results, thus we conclude that unexplained variation in performance responses (e.g. seedling survival) will primarily be accounted for by unknown, uncontrollable natural condition (Wise, 2004). Please refer to Wise (2004) for further discussion of restraints accredited to environmental conditions.

\section{Seedling Survival}

With the intention of reducing negative impacts upon seedlings caused by multiple land use objectives adjacent to the study-site (refer to Wise (2004) for full account), the following preventative techniques were administered: 1) meetings with range managers, 2) placement of chained locks on all border gates, and 3) the installation of gate latches (Pinkerton, 2006). In spite of these actions, some damage from external sources (primarily cattle, deer, and feral pig) was subsequently found in all plots (Pinkerton, 2006). The detriment to survival, growth, and performance was incalculable but is expected and considered a normal part of land management operations. 


\section{MANAGEMENT IMPLICATIONS AND RECOMMENDATIONS FOR FUTURE RESEARCH}

\section{Forest Management}

Endurance of native Monterey pine stands is not assured through a "no action" management strategy (Piirto \& Valkonen, 2005). To more confidently encourage natural regeneration and discourage pitch canker infection of the conifer species in native stands, management guidelines are necessary. The results of this study are still young in terms of lifecycle and lasting sustainability, but recommendations can still be made.

Fifth-year post-treatment survey and analysis attest to the use of 0.10-hectare gaps prepared with a pile and burn site treatment. Albeit results show only a statistically moderate effect of treatment on survival, recorded rates indicate seedlings (both natural and artificial) have a better chance of survival in gaps treated with a pile and burn treatment. Likewise, the 0.10 -hectare gaps are not recommended strictly for significant superiority over the other gap-sizes, but for observable distinction in survival rates.

Although the 0.20 -hectare and 0.10 -hectare gaps show very similar growth measures, the subordinate numbers of naturally regenerated seedlings yielded in 0.20 -hectare gaps 68 -months post-treatment discourage the recommendation of the larger gap-size. Likewise 0.05 -hectare plots are not chosen based on both lower survival odds as well as model results showing significantly lower growth averages than 0.20hectare gaps and significantly lower diameter averages than 0.10-hectare gaps.

High pitch caner infection rate is the one significant drawback to use of 0.10 -hectare gaps. However, with development of more accurate resistance testing and catalog of resistant genotypes, susceptibility and consequential infection occurrence will be decreased.

Considering the study' primary focus to address the need to restore and sustain health (e.g. successful regeneration) in native Monterey pine stands, recommendations are based upon survival rates rather than growth performance. For international populations where yield is of increased interest, review of this study in several years (e.g. 5, 10 or 15) may shed further insight to optimum gap-size. As indicated by study results and information presented in the 'Introduction', fire is a critical element for sustaining healthy Monterey pine populations. I recommend that regardless of gap-size choice that some magnitude 
of fire or burn treatment sustain a steadfast role in the management plan developed for Monterey pine stands.

A wide breadth of genetic diversity is also recommended for native stands as they face ecological and environmental challenges. The use of a variety of locally sourced seedlings for reforestation of gaps will give the stand the best chance for longevity. Parents with the most extreme mortality rates and/or susceptibility to pitch canker (e.g. SP15) should be planted in lesser proportion due to high risk of monetary and labor losses. I do not recommend the full exclusion of susceptible parents from reforestation efforts due to the potential initiation of naturally occurring regeneration. Mortality of pitch canker infected individuals or clusters will create gaps in the canopy that may allow for this aggressively colonizing species to establish seedlings of a new age class (Storer et. al, 2001). Based on our study results and regardless of positive results confirmed in an alternate document (i.e. Gordon et al., 2001), the lesion length measure method (Gordon et. al, 1998) is not recommended as reliable for gauging resistance or survival of parent trees when only mother is controlled.

\section{Future Research Needs}

With study limitations previously discussed, several opportunities for research were eliminated. However, the answers to those questions could prove helpful for stands not impacted by those restrictions. For example, could more extensive fire treatment or larger gaps prove significantly more beneficial to survival and growth performance of artificial seedlings? How would those elements impact germination and establishment of natural regeneration?

Additionally, with afore-mentioned limitations still in place, other silvicultural techniques could be tested for impact upon survival, growth, and pitch canker infection rates of seedlings (natural and artificial). For example how could supplemental silvicultural measures (e.g. weed management at recommended by Wise (2004)) impact establishment and survival rates of seedlings? Why do larger gapsizes produce higher infection rates of pitch canker? Is there a lesson to be learned from the significant correlation between occurrence of pitch canker and western gall rust symptoms?

Regardless of the population in question (e.g. native or international) better understanding of the genetic phenomenon contributing to survival and pitch canker infection rates could effectively, and 
significantly direct subsequent reforestation and management guidelines (Gordon et al, 2001).

Furthermore, research is needed to determine whether screening methods outlined by Gordon et. al (1998) are appropriate for prediction of infection resistance, and if not, what methods accurately characterize the phenotypic expression of resistance of parent trees. 


\section{CONCLUSIONS}

Future ecological and financial value of Monterey pine is reliant upon healthy native stands.

Problems for the species' native populations caused by urban fragmentation, introduction of invasive vegetation, and genetic contamination are exacerbated by decreased regeneration (i.e. suppression resulting from fire policy and association with shade-tolerant broadleaf species) and the introduction of pitch canker. Taking no action to combat these threats is anticipated to result in more advanced deterioration, whereas gap-openings in the canopy and use of resistant seed stock (e.g. pitch canker) can help counterbalance the aforementioned regeneration constraints and contribute to restored forest health (Piirto \& Valkonen, 2005; Storer et. al., 2001).

The results of this study confirm the following conclusions for survival, growth, and disease infection of Monterey pine seedlings within uneven-aged silvicultural management strategy:

Seedling Survival:

1. Gaps prepared with pile and burn site treatment produce higher survival rates than gaps treated with lop and scatter site treatment (68- months post-treatment). This site-preparation technique abides by regulations mandated for the study site.

2. Gap-size (i.e. 0.20-, 0.10-, and 0.05-hectare) does not have a significant effect on seedling survival (68months post-treatment).

3. A range in parent survival rates for the 13 tested parents indicates a genotypic impact on survival success. Thus, seed source is an important consideration for reforestation.

\section{Seedling Growth:}

1. Seedling growth (i.e. height or diameter) is not significantly affected by site-treatment (68-months posttreatment).

2. Gap-size has a partially significant effect on seedling height (68-months post-treatment). Seedlings in 0.20-hectare gaps had average heights significantly larger than those in 0.05-hectare gaps. 
3. Gap-size has a partially significant effect on seedling diameter (68-months post-treatment). Seedlings in 0.20-hectare gaps had average diameters significantly larger than those in 0.05-hectare gaps.

4. Seedling growth it not significantly affected by parent tree (68-months post-treatment).

Disease:

1. Pitch canker infection rates are not significantly associated with site treatment (68-month posttreatment).

2. Pitch canker infection rates are significantly associated with gap-size though this may be confounded by tree height (68-month post-treatment).

3. A range in pitch canker infection rates by parent indicates a genetically linked resistance (68-month post-treatment). Thus, seed source is an important consideration for reforestation.

Artificial gap-phase regeneration as explored by this study in synthesis with other techniques may provide a sound foundation for development of an effective management plan critical for restoring health in native Monterey pine stands. Namely, a combination of genetic conservation (in situ and ex situ) and prohibition of exotically propagated Monterey pines will help to maintain invaluable genetic variability and integrity of each distinct population, protecting evolutionary adaptability (Rogers et. al., 2004; Deghi et. al., 1995). Development of a catalog of resistant seed stock will be a critical component to a successful plan as it will allow for successful reforestation of native stands and will eliminate disease losses in international plantations. As our world evolves environmentally, ecologically, politically, legally, and socially, it is important that an appropriate, attentive variety of measures be taken to maintain the prized Monterey pine in the context of the $21^{\text {st }}$ Century and beyond. 


\section{REFERENCES}

Adams, D. 1997. Western Pines and western gall rust. Tree Notes \#22: California Department of Forestry and Fire Protection.

Aegerter, B.J., T.R. Gordon. 2006. Rates of pitch canker induced seedling mortality among Pinus radiata families varying in levels of genetic resistance to Gibberella circinata (anamorph Fusarium circinatum). Forest Ecology and Management 235: 14-17.

Auten, S. 2010. Personal communication. Resource Manager, Swanton Pacific Ranch, Davenport, CA.

California Department of Forestry and Fire Protection (CDF). 2010. California Forest Practice Rules. Title 14, California Code of Regulation, Chapters 4, 4.5, and 10. California Department of Forestry and Fire, Resource Management, Forest Practice Program, Sacramento, CA.

(URL: http://www.fire.ca.gov/resource_mgt/resource_mgt_forestpractice.php)

(Ver. 29. May. 2010)

California Polytechnic State University San Luis Obispo. 2007. Nonindustrial Timber Management Plan: Swanton Pacific Ranch.

(URL: ftp://thp.fire.ca.gov/THPLibrary/North_Coast_Region/NTMPs2007/1-07NTMP-020SCR/) (Ver. 29 May 2010)

Cope, A. 1993. Pinus radiata. In: Fire Effects Information System, [Online]. U.S. Department of Agriculture, Forest Service, Rocky Mountain Research Station, Fire Sciences Laboratory (Producer).

(URL: http://www.fs.fed.us/database/feis/ ) (Ver 8. Oct. 2008)

Dallara, P.D., A.J. Storer, T.R. Gordon, and D.L. Wood. 1995. Current

Status of Pitch Canker Disease in California. Berkeley, California: Department of Environmental Science, Policy and Management, Division of Environmental Biology,

(URL: http://frap.cdf.ca.gov/pitch\%5Fcanker/prevention_management/treenotes.html) (Ver. 23. Jan.2008)

Deghi, G.S., T. Huffman, and J.W. Culver. 1995. California's native Monterey pine population: potential for sustainability. Fremontia 23: 14-23

DiTomaso, J. M., W. T. Lanini. 2009. IPM Education and Publications, UC Statewide IPM Project, University of California, Davis (URL: http://www.ipm.ucdavis.edu) (Ver. 26. Apr. 2010)

Dwinell, L.D. 1999. "Contamination of Pinus radiata seeds in California by Fusarium circinatum." Athens, Georgia: USDA Forest Service, Southern Research Station.

European and Mediterranean Plant Protection Organization and CAB International. Data sheets on quarantine pests: Endocronartium harknessii

(URL: www.eppo.org/QUARANTINE/fungi/.../ENDCHA_ds.pdf)

(Ver.09. May. 2010)

Forde, M.B. 1964. Pinus radiata in California. Forest Research Institute, Rotorua.

Ganley, R.J., M.S. Watt, L. Manning, and E. Iturritxa. 2009. A global climatic risk assessment of pitch canker disease. Can. Jour. of For. Res. 39(11): 2246-2256.

Gordon, T.R. 2006. Pitch canker disease of pines. Phytopathology. 96 (6): 657-659. 
Gordon, T.R., A.J. Storer, and D.L. Wood. 2001. The pitch canker epidemic in California. Plant Disease 85(11): 1128-1139

Gordon, T.R., K.R. Winkler, S.L. Clark, D. Okamota, A.J. Storer, and P. Bonello. 1998. Resistance to pitch canker disease, caused by Fusarium subglutinans f.sp. pini, in Monterey pine (Pinus radiata). Plant Pathology 47: 706-711

Gotou, J., T. Nishimura. 2003. Effects of slash chips placed around trees planted after whole-tree logging: movement and nutrient supply. J. For. Res. 8: 67-76

Harrington, T.C., M.J. Wingfield. 1998. "Diseases and the ecology of indigenious and exotic pines". P. 381-404. In: Richardson, D.M. (ed.) Ecology and biogeography of Pinus. Cambridge University Press, Cambridge.

Henry, B.P. 2005. Monterey Pine (Pinus radiata) in California: Variation Among Native Forests and Health as a Predictor of Tree Removal in an Urban Forest. M.S. thesis Michigan Technological University, Houghton, MI.

Libby, W.J., M.H. Bannister, and Y.B. Linhart. 1968. "The pines of Cedros and Guadalupe Islands." Journal of Forestry 66 (11): 846-853

Lund, U. 2007. Technical Report: Statistical Analysis of Monterey pine seedling growth and survival at 24 months, Swanton Pacific Ranch, 2001-2003. California Polytechnic State University, San Luis Obispo, CA.

Mark, W. 2009. Personal communication. Professor, Cal Poly State University, San Luis Obispo, CA.

McCain, A.H., C.S. Koehler, and S.A. Tjosvold. 1987. Pitch canker threatens California pines. Calif. Agric. 41: 22-23

McCulloch, C.E., S.R. Searle. 2001. Generalized, Linear, and Mixed Models. John Wiley \& Sons, Inc.: New York, New York.

McDonald, P.M., R.J. Laacke. 1990. "Pinus radiata D. Don Monterey pine”. In: Burns, R.M., Honkala, B.H., technical coordinators. Silvics of North America. Volume 1. Conifers. Agric. Handbook. 654. Washington, D.C.: U.S. Department of Agriculture, Forest Service: 433-441.

Moulds, F.R. 1950. Ecology and Silviculture of Pinus radiata (Don) in California and in southern Australia. Doctorial Dissertation, Yale University.

Offord, H.R. 1964. Diseases of Monterey pine in native stands of California and in plantations of western North America. USDA Forest Service, Research Paper PSW-14. P. 1-9. Pacific Southwest Forest and Range Experiment Station, Berkeley, CA.

Oregon State University Extension: An online guide to plant disease control. Western gall rust fact sheet: (URL: http://plant-disease.ippc.orst.edu/disease.cfm?RecordID=858)

(Ver. 09.May. 2010)

Piirto, D.D., S.Valkonen. 2005. Structure and development of pitch canker infected Monterey pine stands at Año Nuevo, California. Forest Ecology and Management 213: 160-174.

Pinkerton, J. 2006. Silvicultural management strategies for pitch canker infected Año Nuevo stands of Monterey pine: second year gap regeneration results, Master Thesis, California Polytechnic State University, San Luis Obispo, CA. 
Rogers, D.L. 2004. In situ genetic conservation of a naturally restricted and commercially widespread species, Pinus radiata. Forest Ecology and Management 197: 311-322

Rogers, D.L., J.J. Vargas Hernández, A.C. Matheson, and J.J. Guerra Santos. 2002. The Mexican island populations of Pinus radiata: an international expedition and ongoing collaboration for genetic conservation. Food and Agricultural Organization of the United Nations. (URL:http://www.fao.org/docrep/005/y4341e/y4341e07.htm\#P947_91075) (Ver. 7 May 2010)

Roy, D.F. 1966. Silvical Characteristics of Monterey Pine. USDA Forest Service Research Paper PSW31. P. 1- 16. Pacific Southwest Forest and Range Experiment Station, Berkeley, CA.

Smith, D.M., B.C. Larson, M.J. Kelty, and P.S. Ashton. 1997. The Practice of Silviculture: applied forest ecology: ninth edition. John Wiley \& Sons Inc: New York, New York.

Storer, A.J., D.L. Wood, and T.R. Gordon. 2002. The Epidemiology of Pitch Canker of Monterey Pine in California. Forest Science 48: 694-700.

Storer, A.J., D.L. Wood, T.R. Gordon, and W.J. Libby. 2001. Restoring native Monterey pine forests in the presence of an exotic pathogen. Jour. of Forestry 99(5): 14-18

Storer, A.J., T.R. Gordon, P.L. Dallara, D.L. Wood. 1994. Pitch canker kills pines, spread to new species and regions. California Agriculture. 48(6): 9-13.

Storer, Andrew J., Thomas R. Gordon, David L. Wood, Paul L. Dallara. Undated.

"Pitch Canker in California." Berkeley, California: Department of Environmental Science, Policy and Management, Division of Environmental Biology.

(URL: http://frap.cdf.ca.gov/pitch_canker/research/pitchcan.html) (Ver. 23 Jan. 2008)

Stuart, J.D., J.O. Sawyer. 2001. Trees and Shrubs of California. P. 89-90. University of California Press, Berkeley.

U.S. Department of Commerce, National Oceanic \& Atmospheric Administration, National Environmental Satellite, Data, and Information Service. 2004.

Climatography of the United States National Climatic Data Center. Asheville, North Carolina. (URL: http://ggweather.com/climate/santa_cruz.htm) (Ver. 29 May 2010)

U.S. Naval Observatory (USNO) Astronomical Applications Department. 2009. Altitude/Azimuth Table for One Day.

(URL: http://aa.usno.navt.mil/cgi-bin/aa/altazw.pl) (Ver. 30 Oct. 2009)

University of California Berkeley. 2010. Jepson Flora Project: Jepson Exchange. Index to Treatments and Keys from The Jepson Manual.

(URL: http://ucjeps.berkeley.edu/interchange/I_treat_indexes.html) (Ver. 25. May. 2010)

White, K. L. 1999. Revisiting native Pinus radiata forests after twenty-nine years. Madroño 46(2): 80-87

Wikler, K., A.J. Storer, W. Newman, T.R. Gordon, and D.L. Wood. 2003. "The dynamics of an introduced pathogen in a native Monterey pine (Pinus radiata) forest." Forest Ecology and Management 179: 209-221.

Wise, E. 2004. Silvicultural management strategies for pitch canker infected Año Nuevo stands of Monterey pine: first year gap regeneration results, Master Thesis, California Polytechnic State University, San Luis Obispo, CA. 


\section{APPENDICES}

Appendix A. Key Photos of Plots and Seedlings

Appendix B. Natural Regeneration Details: 12-, 24-, and 68 months Post-Treatment

Appendix C. Survival and Mortality Details: 68 months Post-Treatment

Appendix D. Growth Averages: 12-, 24-, and 68 months Post-Treatment

Appendix E. Spatial Relationship Schematic

Appendix F. Photographic Record Fifth Year Post-Treatment

Appendix G. Thesis Data 


\section{Appendix A}

Key Photos of Plots and Seedlings 

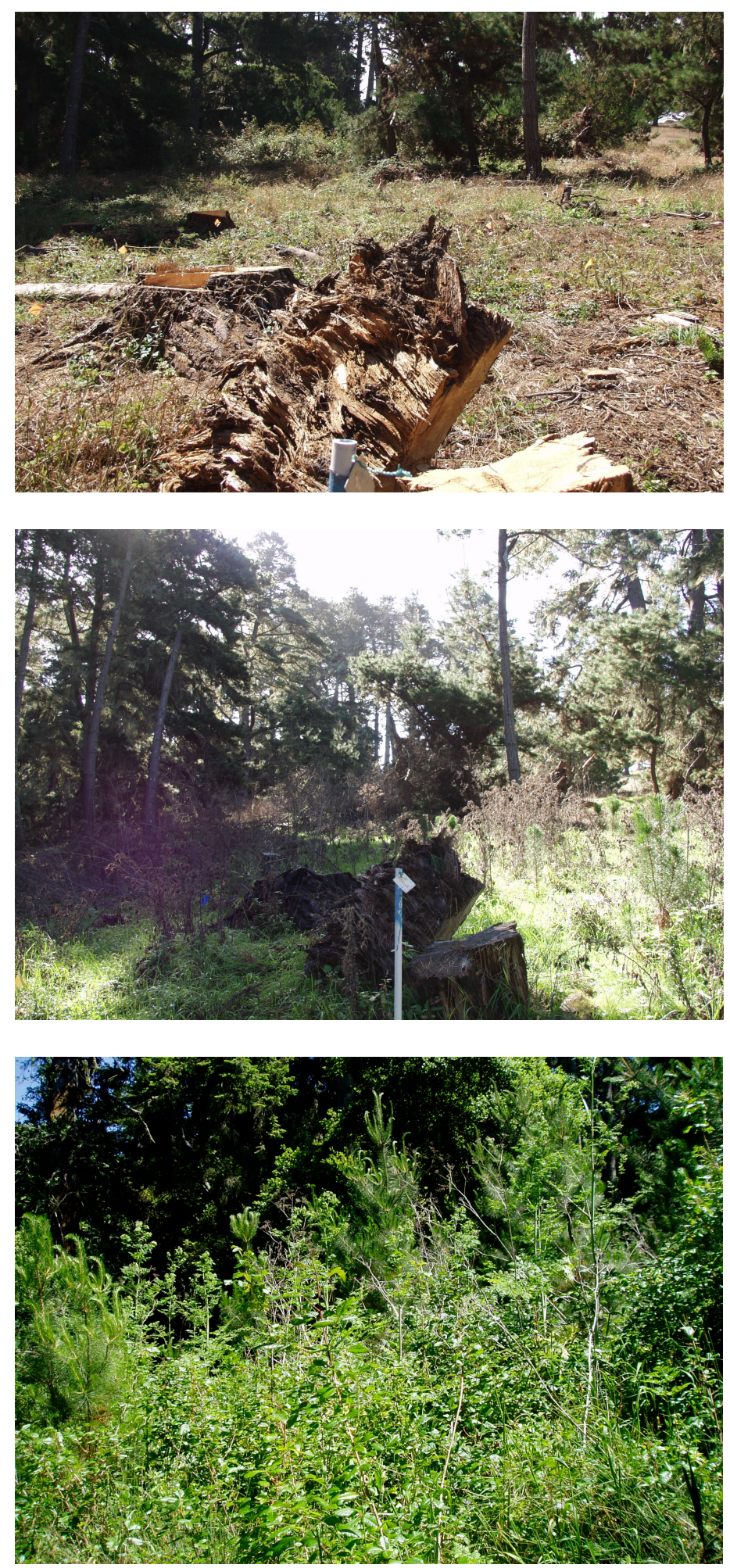

Figure A1. Understory vegetation progression in plot B-4-1 (view from plot center South) at 12-, 24-, and 68month post-treatment. Source: Wise, 2004; Pinkerton, 2006. 

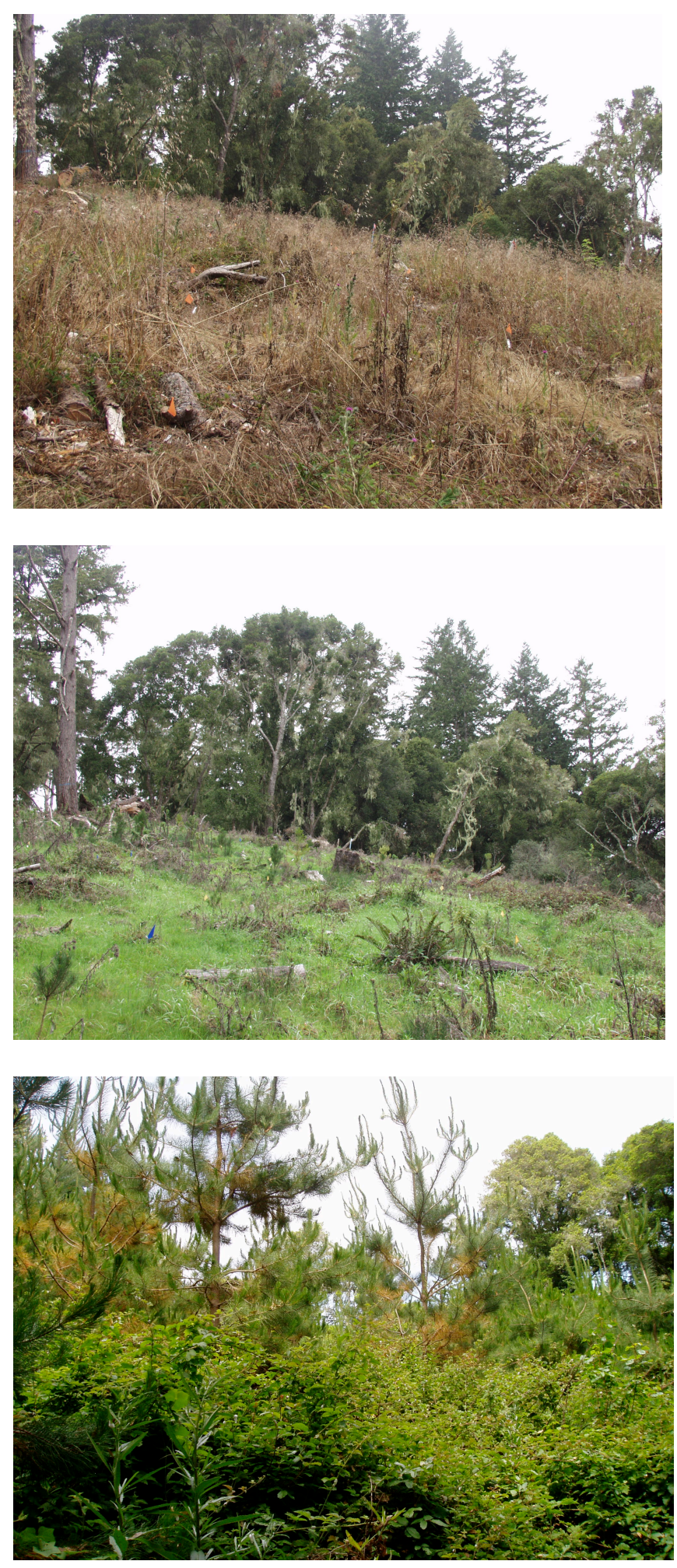

Figure A2. Understory vegetation progression in plot L-2-1 (view from South end of plot looking North) at 12-, 24-, and 68month post-treatment. Source: Wise, 2004; Pinkerton, 2006. 

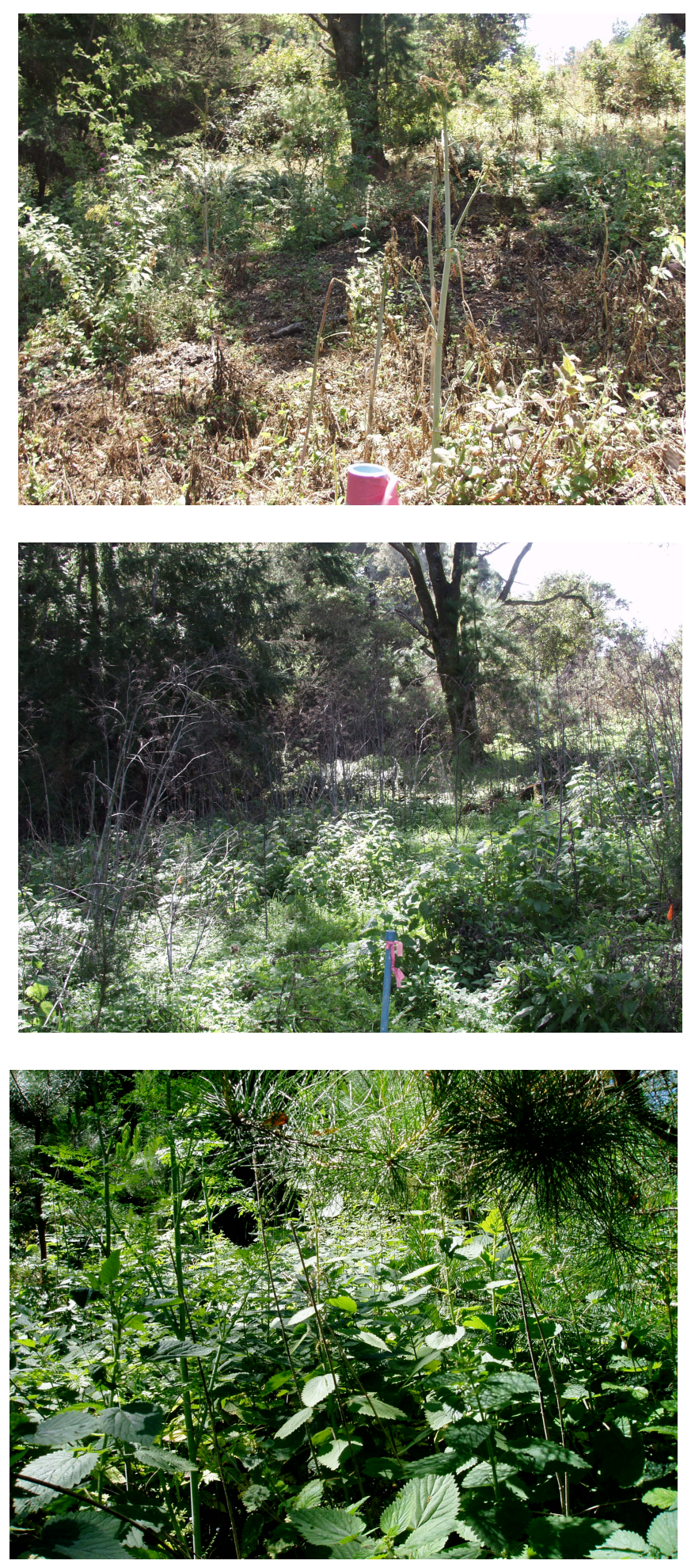

Figure A3. Understory vegetation progression in plot B-8-3 (view from plot center South) at 12-, 24-, and 68month post-treatment. Source: Wise, 2004; Pinkerton, 2006. 

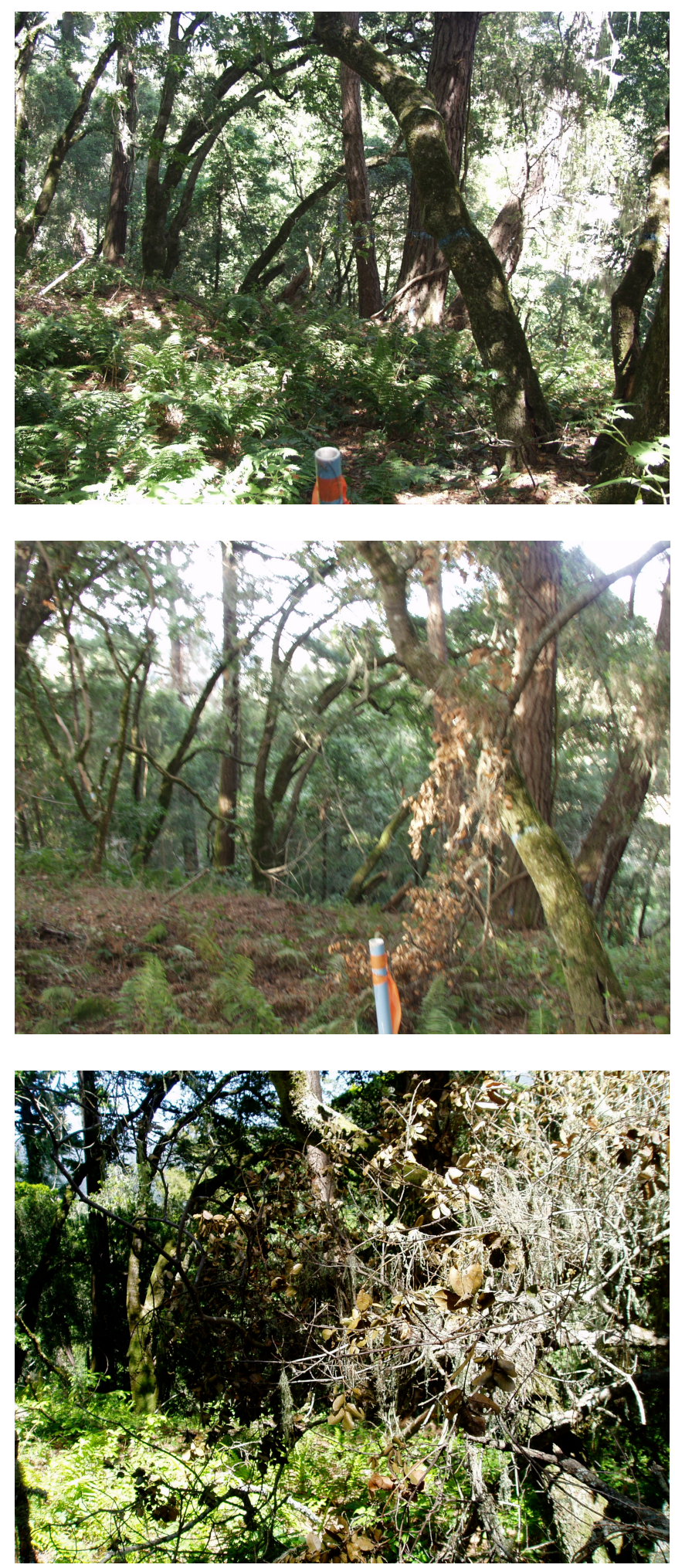

Figure A4. Understory vegetation progression in plot C-8-1 (view from plot center North) at 12-, 24-, and 68month post-treatment. Source: Wise, 2004; Pinkerton, 2006. 


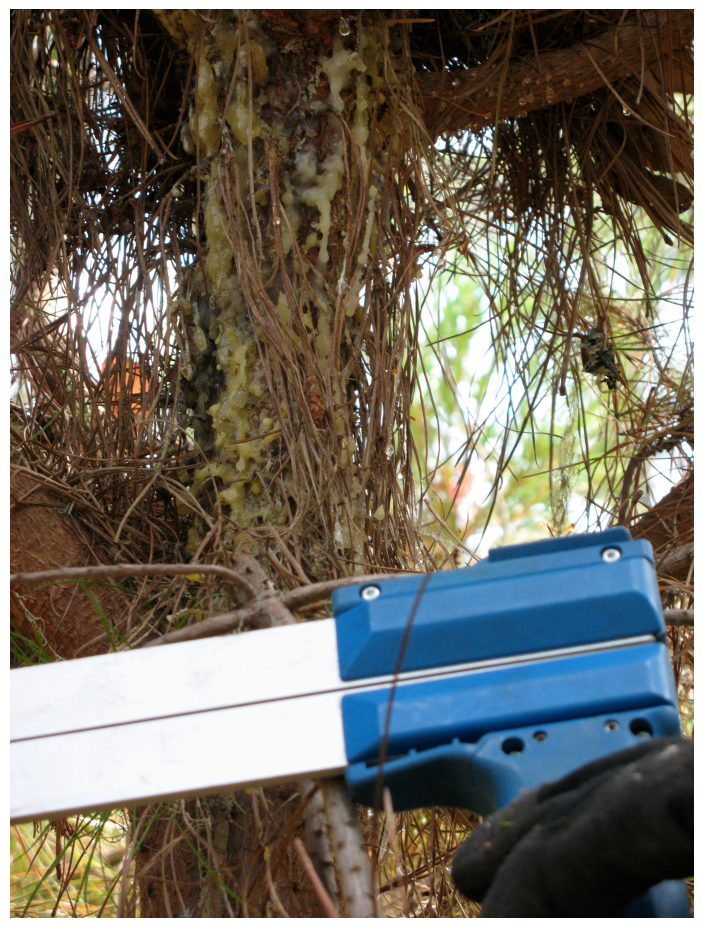

Figure A5. Pitch canker stem canker symptom found on study seedling. Photo: Sarah Mark

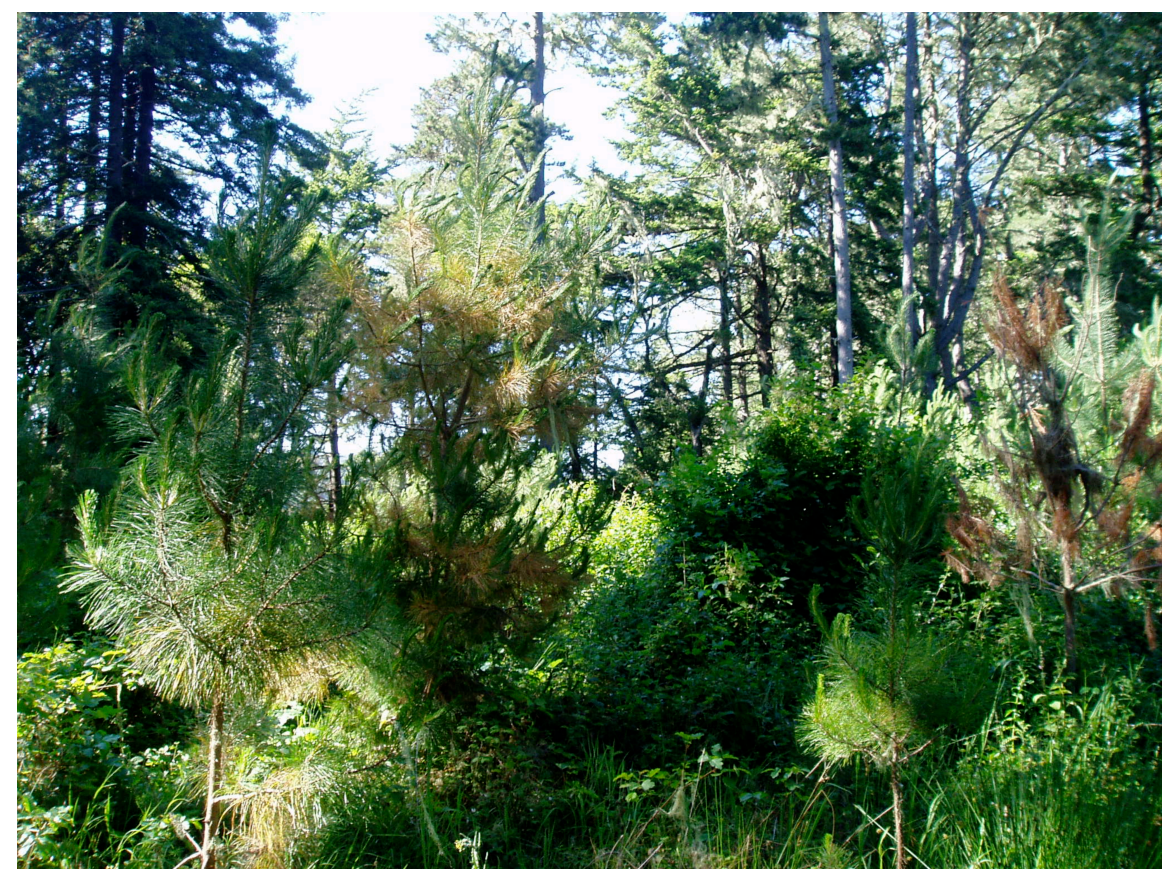

Figure A6. Study seedlings exhibiting pitch canker branch tip symptoms and mortality. 


\section{Appendix B}

Natural Regeneration Details: 12-, 24-, and 68 months Post-Treatment 
Table B1. Natural regenertion survey results by gap-size, site-treatment, and year (all species) Source: (Pinkerton, 2006)

\begin{tabular}{|c|c|c|c|c|c|}
\hline Size & Treatment & Species* & \#Pre-trmt & \#Post-trmt 1 & \#Post-trmt 2 \\
\hline \multirow[t]{4}{*}{0.05 ha } & Control & Qu sp. & 1 & 3 & 2 \\
\hline & & $\mathrm{ToCa}$ & 2 & 2 & 3 \\
\hline & & $\mathrm{UmCa}$ & 1 & 2 & 1 \\
\hline & & All species & 4 & 7 & 6 \\
\hline \multirow[t]{6}{*}{0.05 ha } & Lop \& Scatter & $\mathrm{PiRa}$ & 2 & 4 & 3 \\
\hline & & PsMe & 1 & 1 & 0 \\
\hline & & Qu sp. & 25 & 14 & 5 \\
\hline & & ToCa & 2 & 1 & 4 \\
\hline & & $\mathrm{UmCa}$ & 0 & 0 & 2 \\
\hline & & All species & 30 & 20 & 14 \\
\hline \multirow[t]{4}{*}{0.05 ha } & Pile \& Burn & $\mathrm{PiRa}$ & 4 & 0 & 24 \\
\hline & & Qu sp. & 36 & 10 & 7 \\
\hline & & $\mathrm{ToCa}$ & 4 & 0 & 0 \\
\hline & & All species & 44 & 10 & 31 \\
\hline \multirow[t]{6}{*}{0.10 ha } & Control & AcMa & 26 & 10 & 1 \\
\hline & & $\mathrm{PiRa}$ & 6 & 5 & 12 \\
\hline & & PsMe & 2 & 1 & 1 \\
\hline & & Qu sp. & 43 & 26 & 26 \\
\hline & & ToCa & 1 & 2 & 1 \\
\hline & & All species & 78 & 44 & 41 \\
\hline \multirow[t]{5}{*}{0.10 ha } & Lop \& Scatter & $\mathrm{PiRa}$ & 1 & 0 & 4 \\
\hline & & PsMe & 2 & 0 & 0 \\
\hline & & Qu sp. & 13 & 1 & 2 \\
\hline & & $\mathrm{UmCa}$ & 2 & 0 & 0 \\
\hline & & All species & 18 & 1 & 6 \\
\hline \multirow[t]{3}{*}{0.10 ha } & Pile \& Burn & $\mathrm{PiRa}$ & 1 & 1 & 6 \\
\hline & & Qu sp. & 6 & 0 & 1 \\
\hline & & All species & 7 & 1 & 7 \\
\hline \multirow[t]{6}{*}{0.20 ha } & Control & $\mathrm{ArMe}$ & 0 & 1 & 0 \\
\hline & & PiRa & 3 & 7 & 13 \\
\hline & & PsMe & 1 & 2 & 2 \\
\hline & & Qu sp. & 11 & 10 & 13 \\
\hline & & $\mathrm{UmCa}$ & 0 & 2 & 2 \\
\hline & & All species & 15 & 22 & 30 \\
\hline \multirow[t]{7}{*}{0.20 ha } & Lop \& Scatter & AcMa & 1 & 1 & 1 \\
\hline & & $\mathrm{PiRa}$ & 14 & 1 & 14 \\
\hline & & PsMe & 5 & 1 & 2 \\
\hline & & Qu sp. & 70 & 40 & 33 \\
\hline & & $\mathrm{ToCa}$ & 5 & 2 & 2 \\
\hline & & $\mathrm{UmCa}$ & 2 & 3 & 3 \\
\hline & & All species & 97 & 48 & 55 \\
\hline \multirow[t]{6}{*}{0.20 ha } & Pile \& Burn & $\mathrm{PiRa}$ & 5 & 2 & 15 \\
\hline & & PsMe & 16 & 4 & 4 \\
\hline & & Qu sp. & 97 & 10 & 19 \\
\hline & & ToCa & 15 & 4 & 7 \\
\hline & & $\mathrm{UmCa}$ & 4 & 4 & 3 \\
\hline & & All species & 137 & 24 & 48 \\
\hline \multicolumn{3}{|c|}{ Total for study area: all species } & 430 & 177 & 238 \\
\hline
\end{tabular}

* Species code corresponds to Table 6 . 
Table B2. Natural regeneration counts by treatment and gap-size at $68 \mathrm{~m}$ post-treatment.

\begin{tabular}{|c|c|c|c|c|c|c|c|}
\hline TRT & SIZE & PLOT & $\begin{array}{l}\text { \#NATURAL } \\
\text { REGEN }\end{array}$ & MIN & MAX & AVERAGE & $\begin{array}{c}\text { Category } \\
\text { Sum }\end{array}$ \\
\hline \multirow[t]{4}{*}{$\mathrm{PB}$} & Half: & $\begin{array}{l}\text { B21 } \\
\text { B22 } \\
\text { B23 }\end{array}$ & $\begin{array}{c}13 \\
17 \\
0\end{array}$ & 0 & 17 & 10.00 & 30 \\
\hline & Quarter: & $\begin{array}{l}\text { B41 } \\
\text { B42 } \\
\text { B43 }\end{array}$ & $\begin{array}{c}19 \\
2 \\
15\end{array}$ & 2 & 19 & 12.00 & 36 \\
\hline & Eighth: & $\begin{array}{l}\text { B81 } \\
\text { B82 } \\
\text { B83 }\end{array}$ & $\begin{array}{l}3 \\
6 \\
0\end{array}$ & 0 & 6 & 3.00 & 9 \\
\hline & & & All PB plots: & $\mathbf{0}$ & 19 & 7.75 & 75 \\
\hline \multirow[t]{4}{*}{ LS } & Half: & $\begin{array}{l}\text { L21 } \\
\text { L22 } \\
\text { L23 }\end{array}$ & $\begin{array}{c}6 \\
18 \\
6\end{array}$ & 6 & 18 & 10.00 & 30 \\
\hline & Quarter: & $\begin{array}{l}\text { L41 } \\
\text { L42 } \\
\text { L43 }\end{array}$ & $\begin{array}{c}18 \\
10 \\
3\end{array}$ & 3 & 18 & 10.33 & 31 \\
\hline & Eighth: & $\begin{array}{l}\text { L81 } \\
\text { L82 } \\
\text { L83 }\end{array}$ & $\begin{array}{l}2 \\
3 \\
3\end{array}$ & 2 & 3 & 2.67 & 8 \\
\hline & & & All LS plots: & 2 & 18 & 7.67 & 69 \\
\hline \multirow[t]{4}{*}{ Control } & Half: & $\begin{array}{l}\mathrm{C} 21 \\
\mathrm{C} 22 \\
\mathrm{C} 23\end{array}$ & $\begin{array}{l}2 \\
4 \\
0\end{array}$ & 0 & 4 & 2.00 & 6 \\
\hline & Quarter: & $\begin{array}{l}\text { C41 } \\
\text { C42 } \\
\text { C43 }\end{array}$ & $\begin{array}{l}3 \\
4 \\
0\end{array}$ & 0 & 4 & 2.33 & 7 \\
\hline & Eighth: & $\begin{array}{l}\mathrm{C} 81 \\
\mathrm{C} 82 \\
\mathrm{C} 83\end{array}$ & $\begin{array}{l}2 \\
0 \\
0\end{array}$ & 0 & 2 & 0.67 & 2 \\
\hline & & & All Control plots: & $\mathbf{0}$ & 4 & 1.67 & 15 \\
\hline & All Half plots: & $\begin{array}{l}\text { B21 } \\
\text { B22 } \\
\text { B23 } \\
\text { L21 } \\
\text { L22 } \\
\text { L23 } \\
\text { C21 } \\
\text { C22 } \\
\text { C23 }\end{array}$ & $\begin{array}{c}13 \\
17 \\
0 \\
6 \\
18 \\
6 \\
2 \\
4 \\
0\end{array}$ & 0 & 18 & 7.33 & 66 \\
\hline & All Quarter plots: & $\begin{array}{l}\text { B41 } \\
\text { B42 } \\
\text { B43 } \\
\text { L41 } \\
\text { L42 } \\
\text { L43 } \\
\text { C41 } \\
\text { C42 } \\
\text { C43 }\end{array}$ & $\begin{array}{c}19 \\
2 \\
15 \\
18 \\
10 \\
3 \\
3 \\
4 \\
0\end{array}$ & 0 & 19 & 8.22 & 74 \\
\hline & All Eighth plots: & $\begin{array}{l}\text { B81 } \\
\text { B82 } \\
\text { B83 } \\
\text { L81 } \\
\text { L82 } \\
\text { L83 } \\
\text { C81 } \\
\text { C82 } \\
\text { C83 }\end{array}$ & $\begin{array}{l}3 \\
6 \\
0 \\
2 \\
3 \\
3 \\
2 \\
0 \\
0\end{array}$ & 0 & 6 & 2.11 & 19 \\
\hline \multicolumn{2}{|c|}{ Source: Pinkerton, 2006} & All plots: & & 0 & 19 & 5.89 & 159 \\
\hline
\end{tabular}




\section{Appendix C}

Survival and Mortality Details: 68 months Post-Treatment 
Table C1. Planted seedling mortality by parent and gap at $68 \mathrm{~m}$ post-treatment.

\begin{tabular}{|c|c|c|c|c|c|c|c|c|c|c|c|c|c|c|c|c|c|c|c|c|}
\hline Parent & B21 & B22 & B23 & L21 & L22 & $\mathbf{L 2 3}$ & B41 & B42 & B43 & dentific & tion ${ }^{\text {a }}$ & L43 & B81 & B82 & B83 & L81 & L82 & L83 & Total $^{\text {b }}$ & $\begin{array}{c}\text { Mortality } \\
\text { by } \\
\text { parent }^{\mathbf{d}}\end{array}$ \\
\hline SP1 & 8 & 7 & 3 & 12 & 9 & 10 & 2 & 4 & 4 & 2 & 5 & 2 & 4 & 1 & 1 & 0 & 2 & 2 & 78 & 46.43 \\
\hline SP2 & 10 & 5 & 1 & 10 & 8 & 6 & 4 & 4 & 3 & 4 & 6 & 1 & 4 & 0 & 1 & 2 & 3 & 3 & 75 & 44.64 \\
\hline SP3 & 12 & 6 & 8 & 11 & 11 & 8 & 3 & 7 & 4 & 5 & 7 & 2 & 2 & 1 & 3 & 3 & 3 & 3 & 99 & 58.93 \\
\hline SP4 & 2 & 9 & 4 & 11 & 5 & 7 & 3 & 5 & 3 & 4 & 6 & 1 & 2 & 1 & 2 & 3 & 2 & 2 & 72 & 40.00 \\
\hline SP5 & 10 & 11 & 6 & 12 & 9 & 9 & 4 & 6 & 5 & 5 & 5 & 2 & 3 & 2 & 3 & 2 & 3 & 2 & 99 & 55.00 \\
\hline SP6 & 12 & 7 & 4 & 13 & 12 & 10 & 4 & 3 & 5 & 5 & 6 & 1 & 2 & 0 & 1 & 3 & 3 & 3 & 94 & 52.22 \\
\hline SP15 & 11 & 14 & 15 & 11 & 13 & 13 & 3 & 7 & 8 & 5 & 7 & 7 & 3 & 4 & 1 & 3 & 4 & 3 & 132 & 73.33 \\
\hline $\mathrm{BC} 3$ & 10 & 2 & 4 & 10 & 10 & 10 & 2 & 5 & 1 & 4 & 7 & 3 & 2 & 0 & 2 & 2 & 1 & 4 & 79 & 47.02 \\
\hline $\mathrm{BC} 4$ & 11 & 6 & 6 & 11 & 8 & 8 & 6 & 5 & 5 & 5 & 5 & 0 & 2 & 2 & 3 & 3 & 1 & 3 & 90 & 50.00 \\
\hline BC6 & 11 & 4 & 1 & 12 & 9 & 9 & 4 & 7 & 3 & 6 & 6 & 3 & 0 & 2 & 2 & 3 & 2 & 2 & 86 & 47.78 \\
\hline BC11 & 5 & 7 & 6 & 10 & 4 & 8 & 2 & 4 & 1 & 4 & 6 & 1 & 1 & 2 & 1 & 0 & 3 & 3 & 68 & 37.78 \\
\hline BC12 & 7 & 5 & 4 & 8 & 12 & 8 & 7 & 4 & 4 & 8 & 7 & 4 & 2 & 2 & 1 & 1 & 1 & 3 & 88 & 48.89 \\
\hline $\mathrm{BC} 13$ & 11 & 13 & 7 & 12 & 12 & 9 & 2 & 6 & 3 & 6 & 5 & 3 & 3 & 2 & 1 & 2 & 0 & 3 & 100 & 59.52 \\
\hline Total $^{\mathrm{c}}$ & 120 & 96 & 69 & 143 & 122 & 115 & 46 & 67 & 49 & 63 & 78 & 30 & 30 & 19 & 22 & 27 & 28 & 36 & 1160 & \\
\hline $\begin{array}{l}\text { Mortality } \\
\text { by gap }^{\mathrm{e}}\end{array}$ & 55.56 & 44.44 & 31.94 & 66.20 & 56.48 & 53.24 & 41.07 & 59.82 & 43.75 & 56.25 & 69.64 & 26.79 & 57.69 & 36.54 & 42.31 & 51.92 & 53.85 & 69.23 & 50.88 & \\
\hline
\end{tabular}

${ }^{a}$ Gap Id. Is treatment, size and replication. For example: B21 is Pile \& Burn, half-acre, first replication.

${ }^{\mathrm{b}}$ Total \# of dead trees by parent over all gaps.

${ }^{\mathrm{c}}$ Total \# of dead seedlings by gap, for all parents.

${ }^{\mathrm{d}}$ Percent mortality by parent over all gaps (168 or 180$)$

${ }^{\mathrm{e}}$ Percent mortality by gap (\# of seedlings dead per \# of seedlings in each gap: 216 in half, 112 in quarter and 56 in eighth acre). 
Table C2. Seedlings recorded dead at year 1 or 2 later to be found alive.

\begin{tabular}{|c|c|c|}
\hline DYID \#* & Gap Id. & Parent Id. \\
\hline 440 & L23 & BC4 \\
700 & L42 & SP2 \\
734 & L42 & SP1 \\
882 & L22 & SP5 \\
1251 & B22 & SP4 \\
1294 & B22 & BC3 \\
1357 & B82 & BC12 \\
1670 & B21 & BC6 \\
1694 & B21 & BC6 \\
1707 & B21 & BC11 \\
2031 & L21 & SP1 \\
2075 & L21 & BC4 \\
\hline
\end{tabular}

* Individual GIS seedling identification number 


\section{Appendix D}

Growth Averages: 12-, 24-, and 68 months Post-Treatment 
Table D1. Average seedling height and diameter growth* (measured in $\mathrm{mm}$ ) among hypothesized factors (sitepreparation treatment, gap size and seedling parent)

\begin{tabular}{|c|c|c|c|c|c|c|c|c|c|c|c|c|c|c|c|c|c|}
\hline \multirow[b]{2}{*}{$\begin{array}{c}\text { Factor } \\
\text { Gap Size }\end{array}$} & \multicolumn{5}{|c|}{ February 2003 (12)a } & \multicolumn{5}{|c|}{ February 2004 (24)a } & \multicolumn{5}{|c|}{ October 2007 (68)a } & \multicolumn{2}{|c|}{ Average Growth } \\
\hline & $\mathrm{n}$ & $\begin{array}{l}\text { Mean- } \\
\mathrm{H} \mathrm{cm}\end{array}$ & $\begin{array}{c}\text { SD- } \\
\mathrm{H} \mathrm{cm}\end{array}$ & $\begin{array}{l}\text { Mean- } \\
\text { D mm }\end{array}$ & $\begin{array}{c}\text { SD- } \\
\text { D } \\
\mathrm{mm}\end{array}$ & $\mathrm{n}$ & $\begin{array}{l}\text { Mean- } \\
\mathrm{H} \mathrm{cm}\end{array}$ & $\begin{array}{l}\text { SD- } \\
\text { D cm }\end{array}$ & $\begin{array}{l}\text { Mean- } \\
\text { D mm }\end{array}$ & $\begin{array}{c}\text { SD-D } \\
\mathrm{mm}\end{array}$ & $\mathrm{n}$ & $\begin{array}{l}\text { Mean- } \\
\mathrm{H} \mathrm{cm}\end{array}$ & $\begin{array}{l}\mathrm{SD}-\mathrm{H} \\
\mathrm{cm}\end{array}$ & $\begin{array}{l}\text { Mean- } \\
\text { D mm }\end{array}$ & $\begin{array}{c}\text { SD- } \\
\text { D } \\
\text { mm }\end{array}$ & $\begin{array}{l}\text { Height } \\
\mathrm{cm}\end{array}$ & $\begin{array}{c}\text { Diameter } \\
\mathrm{mm}\end{array}$ \\
\hline 0.05 ha & 61 & 30.08 & 16.26 & 4.826 & 1.8 & 49 & 66.90 & 34.80 & 10.389 & 5.1 & 38 & 290.76 & 149.67 & 39.355 & 26.2 & 129.25 & 18.190 \\
\hline 0.10 ha & 99 & 32.83 & 16.76 & 5.664 & 2.5 & 85 & 72.99 & 38.35 & 12.217 & 6.4 & 77 & 409.70 & 184.51 & 70.726 & 38.8 & 171.84 & 29.536 \\
\hline 0.20 ha & 224 & 36.71 & 18.80 & 6.223 & 3.0 & 181 & 78.74 & 39.12 & 14.681 & 7.6 & 156 & 416.93 & 149.45 & 71.540 & 35.3 & 177.46 & 30.815 \\
\hline Total & \multicolumn{5}{|l|}{384} & \multicolumn{5}{|l|}{315} & \multicolumn{5}{|l|}{271} & & \\
\hline \multicolumn{18}{|l|}{ Gap Trtmt } \\
\hline $\begin{array}{l}\text { Lop \& } \\
\text { Scatter }\end{array}$ & 184 & 32.67 & 16.76 & 5.563 & 2.5 & 147 & 73.71 & 40.13 & 12.446 & 6.6 & 121 & 382.13 & 185.11 & 65.513 & 39.3 & 162.84 & 27.841 \\
\hline Pile \& & & & & & & & & & & & & & & & & & \\
\hline Burn & 200 & 36.49 & 19.05 & 6.121 & 3.0 & 168 & 78.16 & 36.83 & 14.122 & 7.4 & 150 & 409.33 & 147.00 & 67.831 & 34.8 & 174.66 & 29.358 \\
\hline Total & \multicolumn{5}{|l|}{384} & 315 & & & & & 271 & & & & & & \\
\hline Parent & & & & & & & & & & & & & & & & & \\
\hline SP1 & 34 & 37.08 & 18.03 & 6.248 & 2.8 & 31 & 72.86 & 40.64 & 12.929 & 7.1 & 27 & 396.24 & 176.62 & 67.235 & 37.3 & 168.73 & 28.804 \\
\hline SP2 & 34 & 37.52 & 18.29 & 6.807 & 3.3 & 27 & 80.88 & 34.29 & 15.799 & 8.6 & 25 & 407.82 & 174.89 & 74.863 & 42.9 & 175.41 & 32.490 \\
\hline SP4 & 33 & 34.26 & 15.49 & 5.359 & 2.3 & 25 & 64.28 & 30.48 & 11.049 & 5.6 & 22 & 348.44 & 188.20 & 47.805 & 26.0 & 148.99 & 21.405 \\
\hline SP5 & 26 & 36.17 & 18.03 & 6.477 & 3.3 & 18 & 89.76 & 34.80 & 15.926 & 6.6 & 16 & 430.53 & 184.36 & 75.281 & 39.2 & 185.49 & 32.561 \\
\hline SP6 & 31 & 36.83 & 18.29 & 5.842 & 3.0 & 24 & 87.98 & 37.59 & 13.945 & 7.6 & 19 & 401.05 & 164.69 & 67.978 & 38.0 & 175.29 & 29.255 \\
\hline SP15 & 17 & 28.70 & 15.24 & 4.826 & 2.0 & 15 & 66.86 & 36.58 & 11.049 & 7.4 & 12 & 327.66 & 121.66 & 50.557 & 23.0 & 141.07 & 22.144 \\
\hline $\mathrm{BC} 3$ & 29 & 34.82 & 17.78 & 5.994 & 3.0 & 30 & 74.71 & 39.88 & 13.437 & 8.1 & 23 & 434.01 & 168.20 & 76.531 & 43.2 & 181.18 & 31.987 \\
\hline $\mathrm{BC} 4$ & 25 & 32.66 & 18.29 & 5.613 & 2.5 & 21 & 70.66 & 36.07 & 11.989 & 5.6 & 20 & 404.47 & 148.73 & 61.181 & 32.9 & 169.26 & 26.261 \\
\hline BC6 & 36 & 29.00 & 13.72 & 4.978 & 2.0 & 30 & 58.85 & 30.99 & 10.668 & 5.1 & 26 & 325.32 & 166.05 & 49.510 & 33.5 & 137.72 & 21.719 \\
\hline BC11 & 33 & 42.95 & 23.88 & 7.010 & 3.8 & 30 & 86.98 & 43.94 & 15.926 & 8.6 & 28 & 413.11 & 147.78 & 77.735 & 37.9 & 181.01 & 33.557 \\
\hline BC12 & 31 & 29.57 & 17.78 & 5.182 & 2.5 & 24 & 69.49 & 39.12 & 12.167 & 5.8 & 21 & 404.22 & 159.96 & 66.760 & 35.1 & 167.76 & 28.036 \\
\hline BC13 & 25 & 34.59 & 18.29 & 5.359 & 2.0 & 21 & 85.62 & 39.62 & 13.843 & 6.4 & 19 & 413.08 & 148.53 & 74.605 & 32.2 & 177.77 & 31.269 \\
\hline Total & 384 & & & & & 315 & & & & & 271 & & & & & & \\
\hline
\end{tabular}

* Dead seedlings (zeros) have been removed from final calculations. Mortality by parent within the growth sample is shown in Appendix C.

${ }^{\mathrm{a}}$ Sampling interval (month)

Adapted: Pinkerton, 2006 
Table D2. Descriptive statistics for height $(\mathrm{cm})$ for all surviving seedlings at 68 months post-treatment.

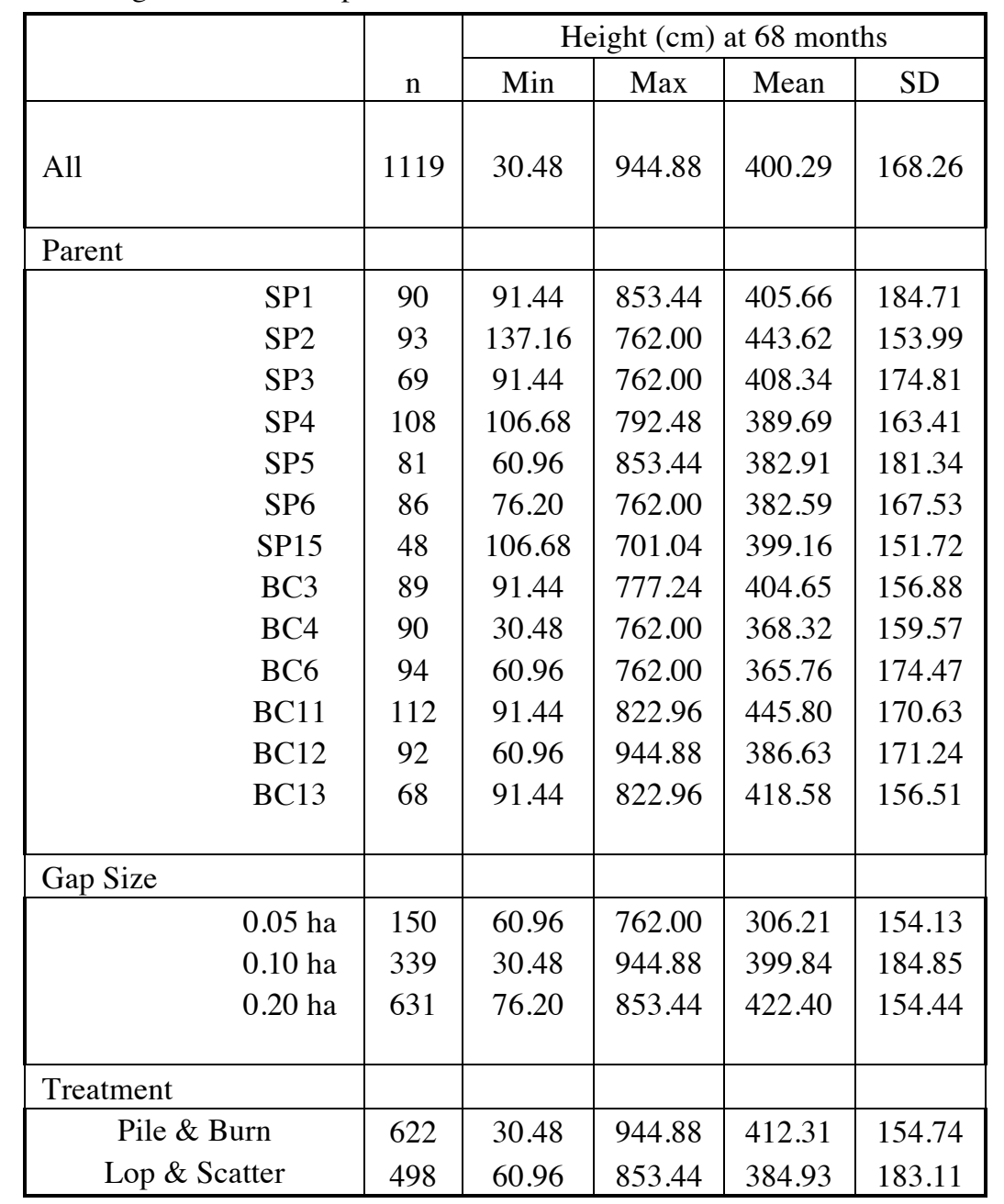

Table D3. Descriptive statistics for diameter ( $\mathrm{mm}$ ) for all surviving seedlings at 68 months post-treatment.

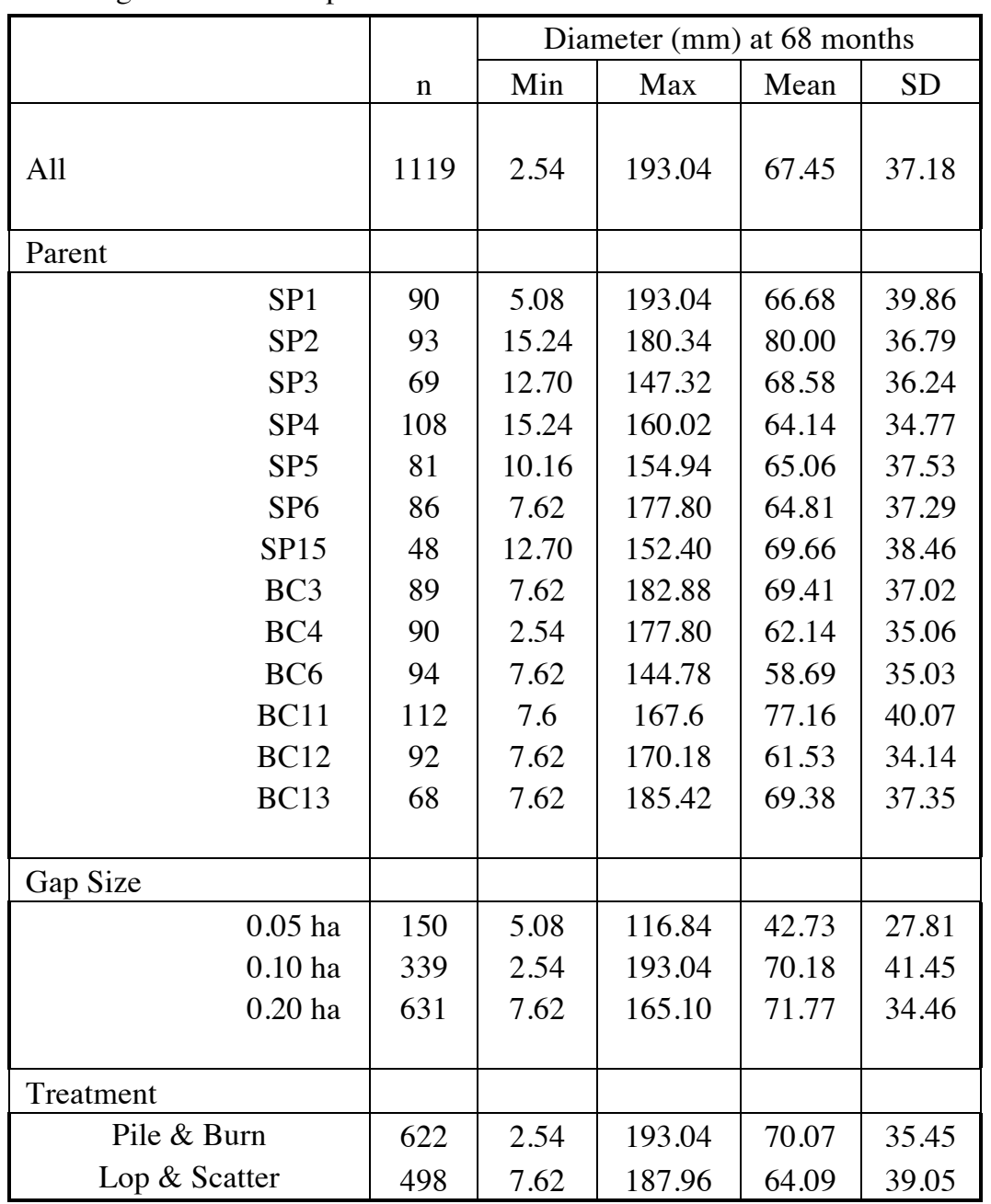




\section{Appendix E}

Spatial Relationship Schematic 


\section{Example Illustration of Spatial Relationship}

Schematic

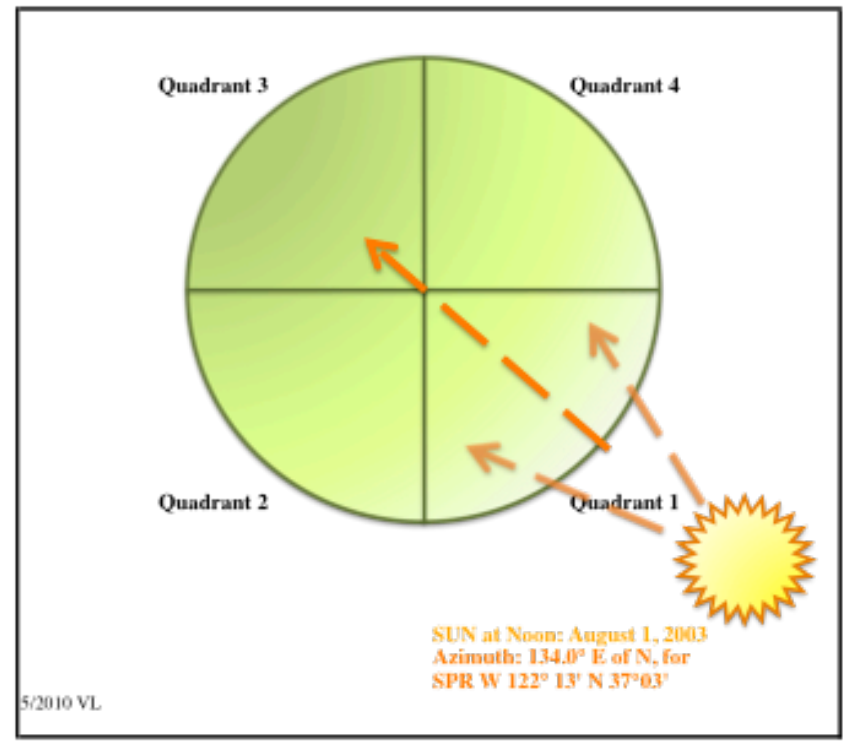

Note: NOT DRAWN TO SCALE. Source: USNO Astronomical Application Dept., 2009. 


\section{Appendix F}

Photographic Record 68 Months Post-Treatment 


\section{Appendix G}

Thesis Data 